\title{
International Benchmarking of Infrastructure Performance in the Southern African Customs Union Countries
}

\author{
by \\ Željko Bogetić and Johannes W. Fedderke
}

Summary: The paper provides a first, systematic benchmarking of infrastructure performance in the SACU countries (South Africa, Botswana, Lesotho, Namibia, and Swaziland) in four major sectors - electricity, water and sanitation, information and communication technology, and transportation - against the relevant group of comparator countries using a new World Bank international data base with objective and perception-based indicators of infrastructure performance from over 200 countries. The analysis suggests important comparative gaps in all major infrastructure sectors, although performance varies widely across the SACU region. Infrastructure performance shortfalls are particularly acute in rural areas where most of the poor reside. The benchmarking is envisaged as a comparative input into deeper analyses of infrastructure performance, especially in the context of the ongoing scaling-up efforts (e.g., South Africa, Lesotho, Botswana).

JEL classification: H54, H, R, O, O57

World Bank Policy Research Working Paper 3987, August 2006

The Policy Research Working Paper Series disseminates the findings of work in progress to encourage the exchange of ideas about development issues. An objective of the series is to get the findings out quickly, even if the presentations are less than fully polished. The papers carry the names of the authors and should be cited accordingly. The findings, interpretations, and conclusions expressed in this paper are entirely those of the authors. They do not necessarily represent the view of the World Bank, its Executive Directors, or the countries they represent. Policy Research Working Papers are available online at http://econ.worldbank.org.

Authors: Bogetic is a lead economist at the World Bank, Africa Region, Washington D.C. (Email: zbogetic@worldbank.org) and Fedderke is professor of economics at the University of Cape Town, School of Economics (Email: jfedderk@commerce.uct.ac.za). 


\section{TABLE OF CONTENTS}

Introduction ........................................................................................................................ 1

The Benchmarking Database .............................................................................................. 2

Infrastructure Performance in the SACU: A Synthetic Overview........................................ 4

Energy_electricity: An Overall assessment for SACU Countries ...................................... 5

Water \& Sanitation: An Overall Assessment for SACU Countries.......................................... 7

Information and Communications Technology (ICT): An Overall Assessment for SACU.... 8

Transport: An Overall Assessment for SACU Countries ...................................................... 12

Reflections on Regional Integration and Regional Infrastructure Policy ................................ 14

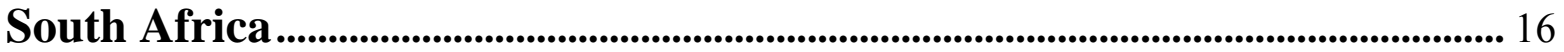

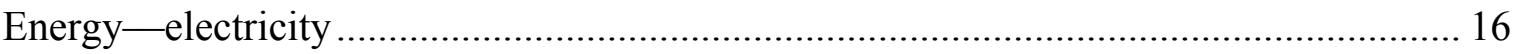

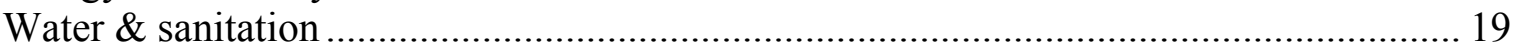

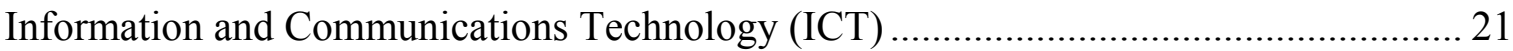

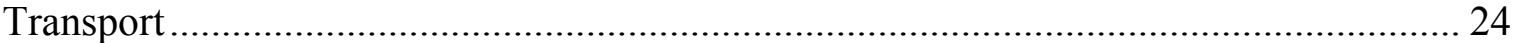

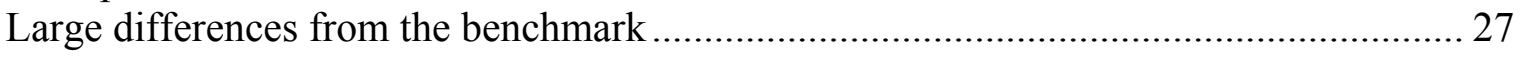

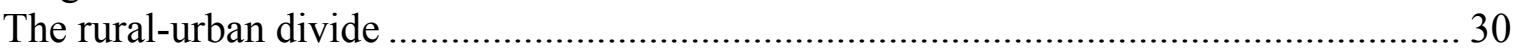

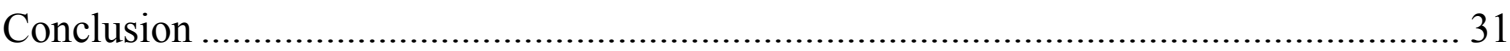

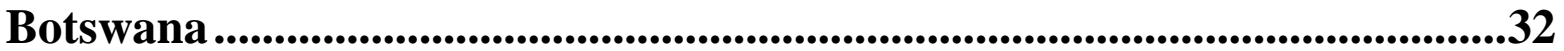

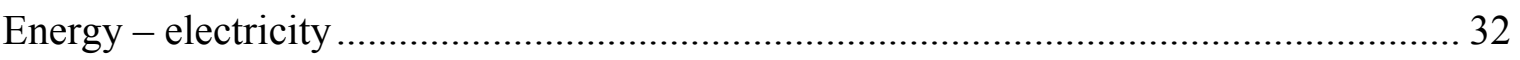

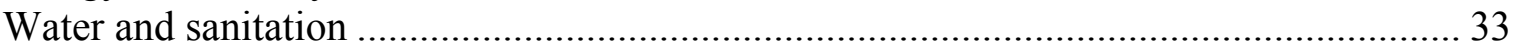

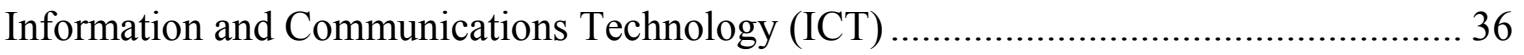

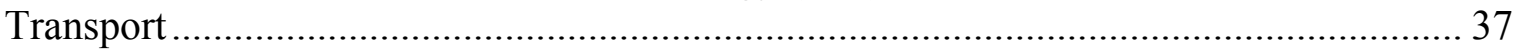

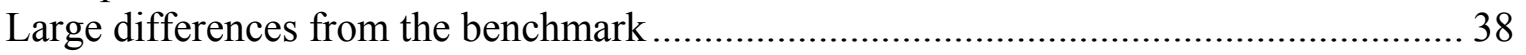

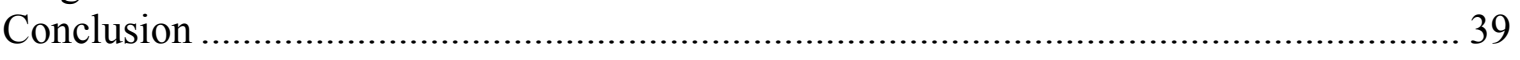

Lesoto ..............................................................................................................40

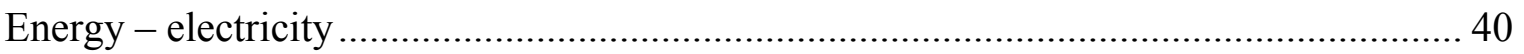

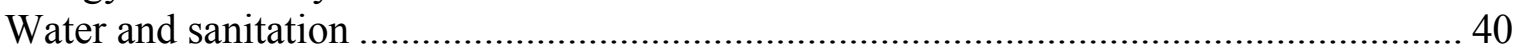

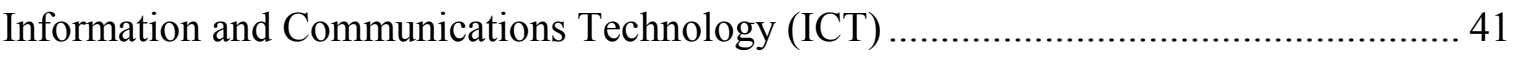

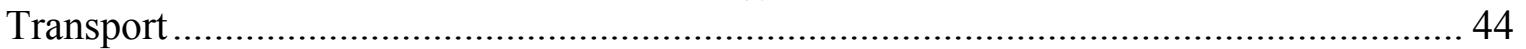

Large differences from the benchmark ............................................................ 44

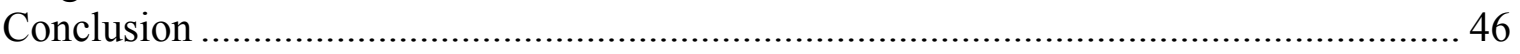

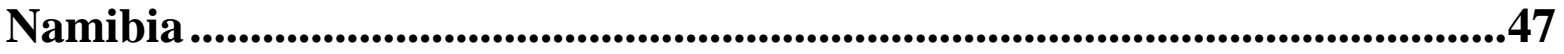

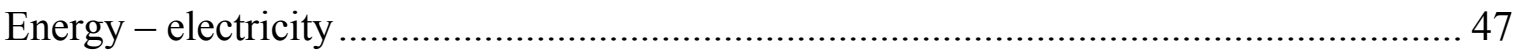

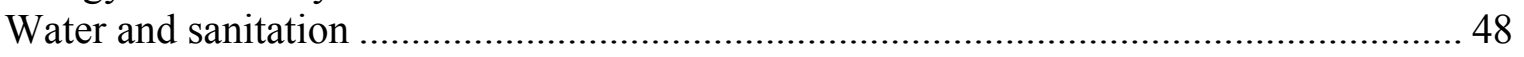

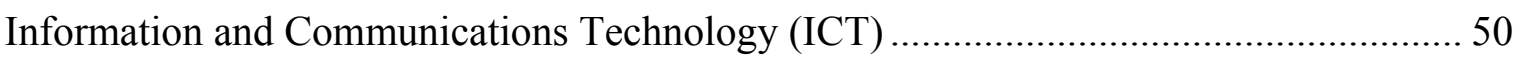

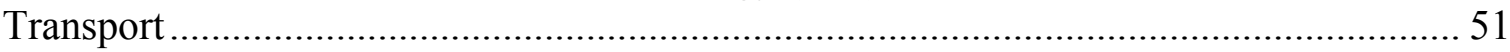

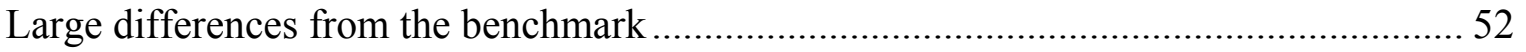

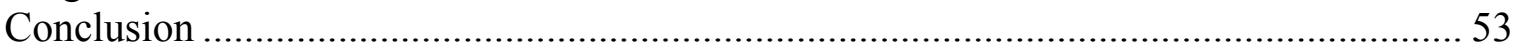

Swaziland .............................................................................................................54

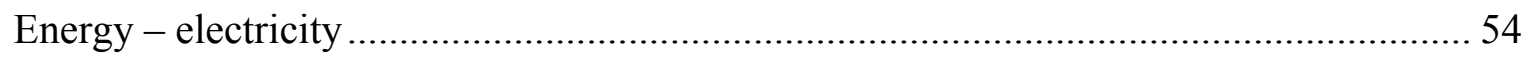

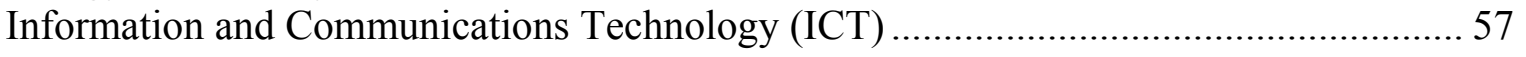

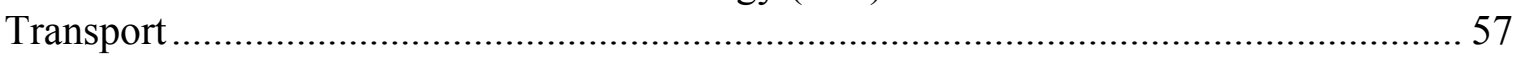

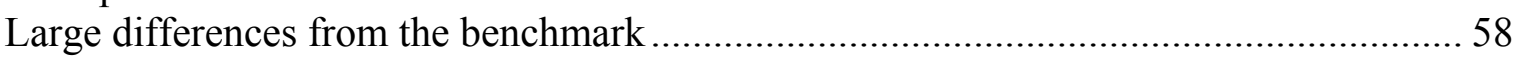

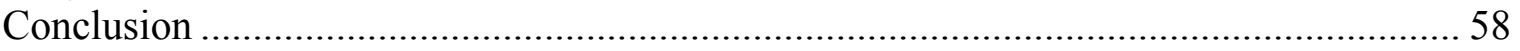

References ................................................................................................59 


\title{
International Benchmarking of Infrastructure Performance in the Southern African Customs Union Countries
}

\author{
Željko Bogetić and Johannes W. Fedderke*
}

\section{INTRODUCTION}

The quantity, quality, and performance of a country's infrastructure affect its level of economic activity and growth prospects. This old theme in development economics is now back center stage on the development agenda, especially in Sub-Saharan Africa. At the same time, there is considerable rethinking of the experience and role of infrastructure in development at the World Bank (Bourguignon 2006). The generally strong association between infrastructure and growth is now well established in recent empirical and broader, comparative analyses (e.g., Canning 2006, Estache 2006, Fedderke and Bogetić 2006, Calderon and Serven 2004; World Development Report 1994, 2005; Aschauer 1989). But during the 1990s, underinvestments in infrastructure in Latin America and Sub-Saharan Africa have led to lower economic growth (Esfahani and Ramirez 2003; and Easterly and Servén 2002), contributing to the "lost decade" for economic and social progress. More broadly, infrastructure affects human welfare, especially of the poor, directly and indirectly via access to and quality of basic services such as water and sanitation. Finally, infrastructure is also associated with child health, human capital accumulation and the achievement of the Millenium Development Goals (MDGs) (Leipziger et al. 2003).

In the Southern African Customs Union (SACU) region, recent research for South Africa, for example, has shown that infrastructure strongly affects economic growth (see, for example, Perkins, Fedderke and Luiz 2005; and Fedderke, Perkins and Luiz 2005). In Lesotho, infrastructure deficiencies have been found to directly constrain private sector activity and economic growth, and the performance of several infrastructure utilities in Swaziland has been seriously lacking (World Bank 2005, 2006). Even in Botswana and South Africa, the SACU countries with the highest gross national income (GNI) per capita and strong overall economic management, new debates have resurfaced on the adequacy of infrastructure performance in the context of the need to sustain and accelerate economic growth. Infrastructure scale-up and modalities of its implementation in the context of the government's new Accelerated and Shared Growth Initiative (ASGI-SA) is currently a key policy issue in South Africa (Manuel 2005, 2006). In a word, concern with infrastructure performance is a critical policy question in the SACU countries, as well as in the African region as a whole.

\footnotetext{
* Bogetić is a lead economist at the World Bank, Africa Region, Washington D.C. (E-mail: zbogetic@worldbank.org) and Fedderke is professor of economics at the University of Cape Town, School of Economics (E-mail: jfedderk@commerce.uct.ac.za). The paper synthesizes and extends to the whole SACU region earlier benchmarking exercises for South Africa (Bogetić and Fedderke, 2006b) and Lesotho (Bogetić 2006). Helpful discussions with Ritva Reinikka, Emmanuel Akpa, Anton Eberhard, Ioannis Kessides, Luiz Maurer, Antonio Estache, Cecilia Briceno-Garmendia, Luis Guasch and Vivien Foster are gratefully acknowledged. Preliminary findings of this paper were presented at a seminar at the Africa Region (AFTP3) of the World Bank in April 2006. The authors also wish to express gratitude for excellent research assistance by Atsede Aemro-Selassie.
} 
Effective infrastructure scale-up, however, requires an assessment of performance of various infrastructure sectors. Yet surprisingly, detailed and sufficiently extensive comparative data on multiple dimensions of infrastructure performance are only now emerging, and there are few systematic, comparative studies of infrastructure performance that would help the policymakers put their sector performance in perspective as a first step in charting future infrastructure policy. In particular, analyzing and benchmarking international comparative performance can be a useful part of such assessments in order to identify dimensions (quantitative and qualitative) of infrastructure performance where SACU countries score better, on par, or worse than their relevant comparators. This paper aims to fill this gap in comparative literature on infrastructure performance. In large part, it synthesizes and extends earlier exercises for South Africa and Lesotho to the entire SACU region (Bogetic and Fedderke 2006b, and Bogetić 2006c). In addition, the paper speculates about the implications of the analysis for the regional infrastructure policy in the SACU countries.

The purpose of this paper, therefore, is to systematically benchmark the SACU countries' infrastructure performance in four major sectors-electricity, water and sanitation, information and communication technology, and transportation. The comparison is made against the relevant group of comparator countries using a new international data base with objective and perception-based indicators of infrastructure performance from over 200 countries. Specifically, we seek to answer a number of relevant questions: How do SACU countries compare on major indicators of infrastructure sector performance against their relevant country groups? What do outcome indicators tell us about the relative strengths and weaknesses of SACU countries' infrastructure vis-à-vis various income and geographical comparator groups of countries? Where are the largest deviations - positive and negativefrom the benchmarks and other comparators? And how does one interpret some of these comparisons to be useful for policy purposes? The answers to these questions are likely to provide important building blocks towards a more complete assessment of the state of infrastructure in the SACU countries, its performance, and any need for reform. It would also help frame the ongoing discussion in the sub-region in a comparative perspective and based on well-defined and widely accepted performance indicators.

The organization of the paper is the following. In the next section, we first provide a brief description of the data and its caveats, and discuss the choice of the comparator groups of countries. Then, we provide a broad, SACU-wide synthetic summary of individual country comparative exercises using average indicators for SACU countries and comparing them with all the world regions and the relevant income level country groupings (middle-income and lowincome countries). We also offer some reflections on the regional implications of such exercises. Finally, in the following five detailed sections, we present individual benchmarking case studies for South Africa, Botswana, Lesotho, Namibia, and Swaziland. These studies provide international comparative assessments of these countries' infrastructure performance in electricity, water and sanitation, information and communications technology, and transportation.

\section{THE BENCHMARKing DATABASE}

The data used for comparing SACU countries' infrastructure performance comes from the World Bank research data base that was recently developed with a specific objective 
to be used for this type of benchmarking exercise (Eustache and Goicoechea, 2005). The database pulls together the latest available observations from a number of well documented, specialized data sources that contain more detailed data with longitudinal information. The data base aims to measure sector performance by focusing on sector outcomes-access, affordability/pricing, and quality (technical or perceived). It also provides information on sector institutional reform. Data cover 207 countries (although coverage varies by sector and indicator) ${ }^{1}$ with a limited number of variables ${ }^{2}$ measuring sector outcomes.

For the purpose of benchmarking SACU countries, we compare each SACU country (and, in the synthetic summary below, the SACU country average indicators) with all the world geographical comparator groups and four groups of countries clustered by level of income per capita. Geographical groupings encompass Sub-Saharan Africa, OECD, South Asia, East Asia \& Pacific, Middle East \& North Africa, Latin America \& the Caribbean, Europe and Central Asia, and the world - and - income groupings cover low-income, middleincome, upper middle-income, and OECD countries. Therefore, both region and income level are used as comparator criteria. The main benchmarking group on which much of the individual country analysis is focused is the specific SACU country per capita income group (upper-middle-income countries for South Africa and Botswana, lower-middle-income country group for Namibia and Swaziland, and low-income country group for Lesotho). Because of the strong association between infrastructure and income level, these are economically the most meaningful group comparator for each country. This is supplemented by relevant comparisons with other income groups and major regions of the world to provide a wider, geographical comparison of the SACU countries infrastructure performance.

As with any comparative indicators summarizing performance in a vast number of different countries, interpretation of comparisons must be made carefully and taken with caution. Some of the variations between the indicators may reflect other factors that may make single indicator comparison less revealing, or even misleading. The database itself has its limitations detailed in the cited World Bank analysis by Estache and Goicoechea. ${ }^{3}$ In addition, where appropriate, we explain or qualify how specific circumstances in specific SACU countries may affect a specific indicator comparison. More broadly, benchmark values of specific performance indicators should not necessarily be construed as "optimal" in the economic sense; in some cases, the benchmark values for comparator group of countries may display "excessive" or "limited" performance in particular indicator due to other, unobservable factors. If so, this would imply that observed "shortfalls" from such biased benchmark values would not be useful for policy purposes. This is a generic problem with all benchmarking. It implies that the results should be taken as indicative-not definitive-of the observed shortfalls from the benchmarks, especially when considering policy implications such as scaling up. Nevertheless, since the benchmarks used are averages of a large number of

\footnotetext{
${ }^{1}$ The percentage of available country observations from the total number of countries (207) varies by indicators from close to $90 \%$ for measures of access to roads, $85-95 \%$ for ICT access and pricing measures, $75-85 \%$ for access to water, and $60 \%$ for access to electricity. The quality indicators generally show lower degrees of completeness than those of access.

${ }^{2}$ The total numbers of indicators in the database in each sector are as follows: 7 in energy, 4 in water \& sanitation, 12 in ICT, and 12 in transport. The availability of indicators and observations varies by country, and is noted in specific SACU countries case studies below.

${ }^{3}$ For example, the database reports the latest information available between 1997 and 2002, corresponding to arithmetic averages of available data. In some cases, more recent within country information may be available that is not yet reflected in the database. Also, efforts to weight the raw data by population could help enhance the quality of the cross-country comparisons.
} 
countries with the same income level as South Africa, the risk of such bias, while difficult to identify, should be minimized. Also, the indicators presented here are widely accepted and fairly unambiguous representations of major dimensions of sector performance. For these reasons, we believe that the benchmarking and comparisons are sufficiently meaningful and could prove useful in both analytical and policy studies of SACU countries' infrastructure performance.

\section{Infrastructure Performance in the SACU: A SyNThetic OVERVIEW}

Overall, the SACU countries, on average, lag behind their comparator groups of countries in several major indicators of access to basic infrastructure services (electricity, water \& sanitation, ICT, and transport), though this performance varies widely across the SACU region. Access performance is particularly lacking in the case of Swaziland whose indicators are more akin to a low-income country rather than a middle-income country that it is. In Lesotho, the only low-income country in the SACU region, access also lags behind its income group of countries. But even in South Africa, despite major gains in recent years in expanding access to electricity to the previously unserviced areas, further extension of access to poor areas is very much needed.

Looking at the SACU region countries' main infrastructure sectors, telephony and electricity are generally performing better in comparative terms, while access is particularly lacking in water and sanitation sectors. This is especially true in Lesotho and Swaziland. Where data are available (e.g., South Africa; and for water and sanitation in all countries), the comparison shows a stark rural-urban divide with access in rural areas significantly behind the cities. Botswana's low access to electricity $(10 \%)$ is particularly stark compared with its benchmark income group (87\%). But aggregate indicators may also hide inequities within larger urban areas where many peri-urban communities (e.g., in South Africa) continue to experience access problems with respect to basic infrastructure services. In the telecom sector, technical progress favoring cellular telephony already brings opportunities to SACU countries "leapfrog" from fixed lines to cellular telephony, much more rapidly catching up with comparator countries.

The technical indicators of the quality of infrastructure service (e.g., system losses in electricity; phone fault rates; percentage of paved roads) in the SACU countries vary widely. While some sectors (e.g., electricity) and countries (e.g., South Africa, Namibia) perform well, others (e.g., some dimensions of ICT performance; and even roads), especially in the poorer SACU countries, fall short of expected performance. Nevertheless, subjective perceptions of the quality of service are broadly favorable, but this may well reflect the urban bias in the surveys used to collect information for this indicator.

While data performance indicators in rural vs. urban areas are not available for all countries and sectors, they (and other, supplemental information) do suggest a strong "urban bias" in infrastructure performance in all SACU countries. In South Africa, for example, the available indicators on electricity, water and sanitation, and telephone services suggest that while urban areas score relatively well, there is a significant shortfall in access to improved water and sanitation in rural areas compared with the benchmark upper-middleincome countries. In the poorer SACU countries, some of the infrastructure services that matter most to the poor - water and sanitation - are lacking in rural areas. In Swaziland, for example, 
rural access to improved water sources is $42 \%$, almost half the level of lower-middle-income group and lower than all other groups.

A more detailed synthesis of SACU performance in four major infrastructure sectors is provided below. It is then followed by more in-depth, individual country benchmarking exercises for South Africa, Botswana, Namibia, Lesotho, and Swaziland.

\section{ENERGY-ELECTRICITY: AN OVERALL ASSESSMENT FOR SACU COUNTRIES}

Access-SACU region access to electricity is poor when compared to the middle-income countries but slightly better than the average for Sub-Saharan Africa (SSA), but access varies widely across SACU countries. The SACU country average indicator for access of 24 percent is low compared to over 80 percent in middle-income countries and 15 percent in SSA. Not surprisingly, South Africa's access to electricity network is superior than the other countries in SACU, but still lags its comparable income group of upper-middle-income countries significantly - 66 percent access compared to 87 percent. Lesotho and, perhaps surprisingly, Botswana are the poorest performers with only 6 and 10 percent of the population having access to electricity, much lower than their comparator income groups. Access in Namibia and Swaziland is slightly above the SSA average, but below that of low-income countries.

Affordability-pricing. Average end-user prices for electricity (in US cents/kwh), both residential and non-residential, in the SACU region are one of the cheapest in the world with South Africa having the lowest rate in the SACU region -3 cents for residential and 2 cents for non-residential customers. ${ }^{4}$ SACU average end-user prices are 5 cents for residential and 3 cents for non-residential customers. In contrast, average prices in middle-income countries are 8 and 7 cents, respectively and 6 and 5 cents in SSA. Lesotho has the highest charge for residential customers at 8 cents. These level comparisons must of course be taken with caution. Such information needs to be complemented with data on costs to assess the adequacy of pricing and ascertain any possible cross-subsidization.

Quality-perceptions. In terms of commercial perception of electricity service, the SACU region scores better than all the comparable regions with a 5.4 rating out of 7 ( $7=$ best, $1=$ worst). In contrast commercial perception of electricity services was the lowest in the lowincome countries (2.8) and SSA (4.3) and slightly better in upper-middle-income countries at 5.2. One should be cautious with interpreting this number as it is heavily influenced by South Africa and Namibia in the absence of scores for Lesotho and Swaziland. Furthermore, it may also reflect a selection bias in that the only customers with access to service would normally respond to the question and thus have favorable perceptions.

\footnotetext{
${ }^{4}$ In South Africa, the low user prices do not seem to reflect underpricing, as is the case in many developing countries with the attendant quasi-fiscal losses. Instead, it is a consequence of the low cost structure of what is considered a well-run state electricity company (ESKOM) and the fact that part of the capital stock has already been depreciated; hence, the fixed cost component of the electricity cost/price in South Africa is very low.
} 
Table 1: Benchmarking of SACU Performance in the Energy Sector

\begin{tabular}{|c|c|c|c|c|c|c|c|c|c|c|}
\hline Energy & SACU & Botswana & Lesotho & Namibia & $\begin{array}{l}\text { South } \\
\text { Africa }\end{array}$ & Swaziland & $\begin{array}{l}\text { Upper } \\
\text { Middle } \\
\text { Income }\end{array}$ & $\begin{array}{l}\text { Lower } \\
\text { Middle } \\
\text { Income }\end{array}$ & $\begin{array}{c}\text { Low } \\
\text { Income }\end{array}$ & SSA \\
\hline $\begin{array}{l}\text { Access to Electricity Network } \\
(\% \text { of Population) }\end{array}$ & 24 & 10 & 6 & 20 & 66 & 20 & 87 & 82 & 31 & 15 \\
\hline $\begin{array}{l}\text { Households Reporting Access to Electricity } \\
\text { (\% of households) }\end{array}$ & 65 & .. & .. & .. & 65 & .. & 74 & 84 & 32 & 23 \\
\hline $\begin{array}{l}\text { Energy Use Per PPP GDP } \\
\text { (kg of oil equivalent/1000 PPP dollars, Constant 2000) }\end{array}$ & 178 & .. &.. & 98 & 257 & .. & 249 & 242 & 374 & 364 \\
\hline $\begin{array}{l}\text { Electricity Average End-User Prices (US cents/kWh) - } \\
\text { (Residential/Non-Residential) }\end{array}$ & $5 / 3$ & $4 / 3$ & $8 / 3$ & $4 / 2$ & $3 / 2$ & $4 / 3$ & $9 / 7$ & $8 / 7$ & $6 / 6$ & $6 / 5$ \\
\hline $\begin{array}{l}\text { Commercial Perception of Electricity service } \\
\text { (1=worst } 7=\text { best) }\end{array}$ & 5.4 & 4.8 & .. & 5.6 & 5.8 & .. & 5.2 & 4.2 & 2.8 & 4.3 \\
\hline $\begin{array}{l}\text { Commercial Perception of Public Agency Electricity Provider } \\
\text { (1=worst } 7=\text { best) }\end{array}$ & 6.0 & 5.7 & .. & 6.3 & 6.0 & .. & 5.3 & 5.0 & 4.0 & 4.3 \\
\hline $\begin{array}{l}\text { Electric Power Transmission and Distribution Losses } \\
\text { (\% of total output) }\end{array}$ & 8.0 & .. & .. & .. & 8.0 & .. & 14.0 & 15 & 22.0 & 19.0 \\
\hline
\end{tabular}

Note: Data used is from the latest observation available between 1997 and 2003.

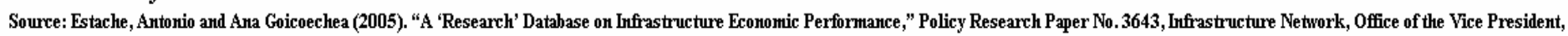
June 2005.

Figure 1: Access to Electricity Network (\% of Population)

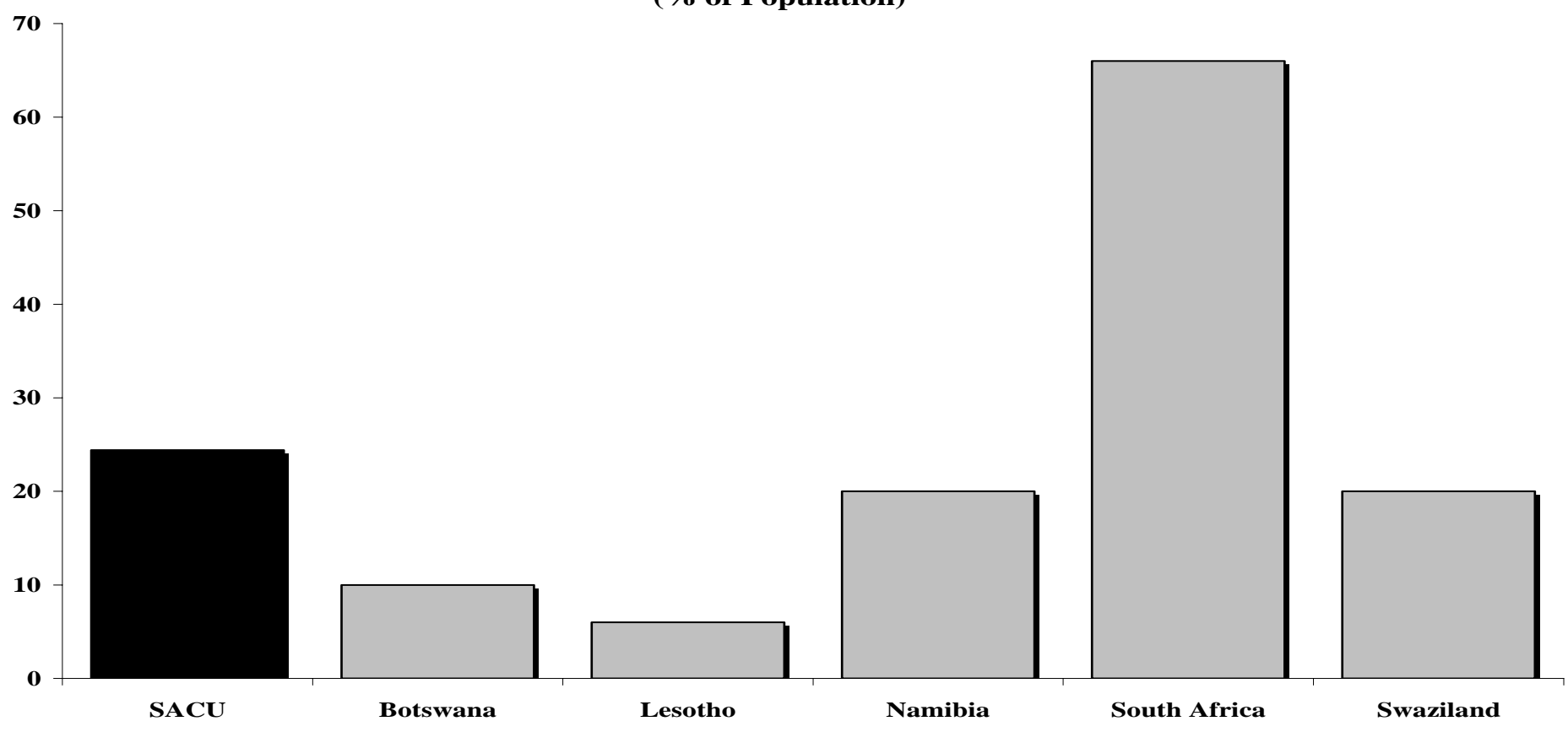




\section{WAter \& Sanitation: An Overall Assessment for SACU Countries}

Access - Overall access to improved water sources in the SACU region is significantly lower than the middle income average but much better than SSA. Only 78 percent of the populations have access to improved water sources with Botswana having highest coverage at 95 percent followed by South Africa at $87 \%$. By far the worst performer is Swaziland with just over half the population having access to improved water sources followed by Lesotho at 76 percent. Swaziland's coverage is also poor when compared with SSA.

The performance of SACU region in terms of access to improved sanitation is particularly worrisome. It is worse than the situation with access to improved water and very disappointing given the fact that four of the five countries are middle income. With only 45 percent of the population having access to improved sanitation, the SACU region lags far behind the middle income countries and is only slightly ahead of the low-income group. Even the best performing country, South Africa, lags its comparable income group by around 20 percentage points.

Quality-perception. The SACU region gets one of the highest ratings in commercial perception of water services, scoring 5.9 out of 7 , but this may reflect the urban bias of this indicator. Upper-middle-income countries are rated 5 and even OECD countries are lower at 5.2. Again, this may represent the view of the satisfaction with service by the segments of the population already enjoying access. Also, it may reflect the "urban bias" of the perception indicator, and may hide differences between the quality of service in urban versus rural communities.

Table 2: Benchmarking of SACU's Performance in the Water \& Sanitation

\begin{tabular}{|c|c|c|c|c|c|c|c|c|c|c|}
\hline Water & SACU & Botswana & Lesotho & Namibia & $\begin{array}{l}\text { South } \\
\text { Afica }\end{array}$ & Swaziland & $\begin{array}{l}\text { Upper } \\
\text { Middle } \\
\text { Income }\end{array}$ & $\begin{array}{l}\text { Lower } \\
\text { Middle } \\
\text { Income }\end{array}$ & $\begin{array}{l}\text { Low } \\
\text { Income }\end{array}$ & SSA \\
\hline $\begin{array}{l}\text { Access to Improved Water Sources } \\
(\% \text { of population })\end{array}$ & 78 & 95 & 76 & 80 & 87 & 52 & 93 & 85 & 65 & 64 \\
\hline $\begin{array}{l}\text { Access to Improved Sanitation } \\
(\% \text { of population) }\end{array}$ & 45 & 41 & 37 & 30 & 67 & 52 & 86 & 72 & 41 & 37 \\
\hline $\begin{array}{l}\text { Commercial Perception of Water Service } \\
\text { (1=worst 7=best) }\end{array}$ & 5.9 & 5.7 & . & 6.2 & 5.7 & ." & 5.0 & 4.8 & 4.0 & 4.2 \\
\hline $\begin{array}{l}\text { Households Using Piped or Well Water as Main Source of } \\
\text { Drinking Water (\% of households) }\end{array}$ & 85 & " & " & " & 85 & ". & 80 & 82 & 78 & 78 \\
\hline
\end{tabular}

Note: Data used is from the latest observation available between 1997 and 2003.

Source: Estache, Antonio and Ana Goicoechea (2005). "A 'Research' Datahase on Infrastructure Economic Perforntance," Policy Research Paper No.3643, Infrastructure Network, Office of the Vice President, Jure 2005. 
Figure 2: Access to Improved Water Sources

(\% of Population)

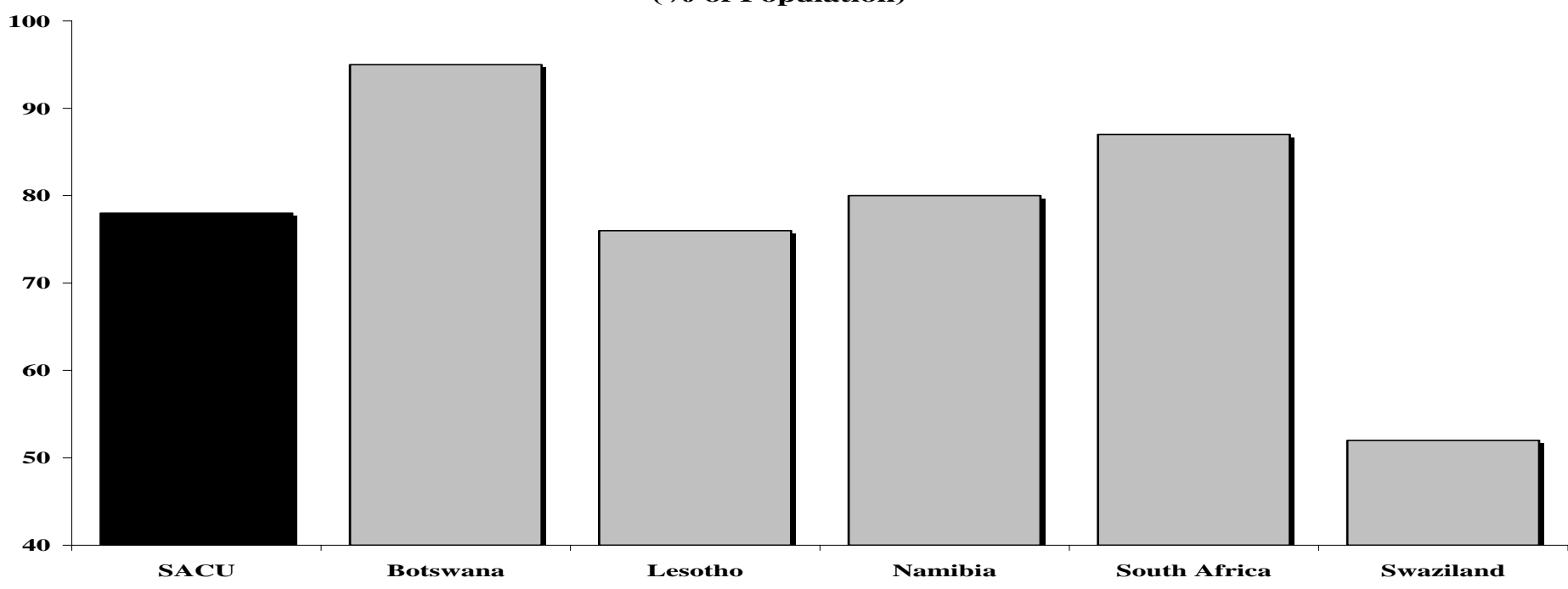

Figure 3: Access to Improved Sanitation (\% of Population)

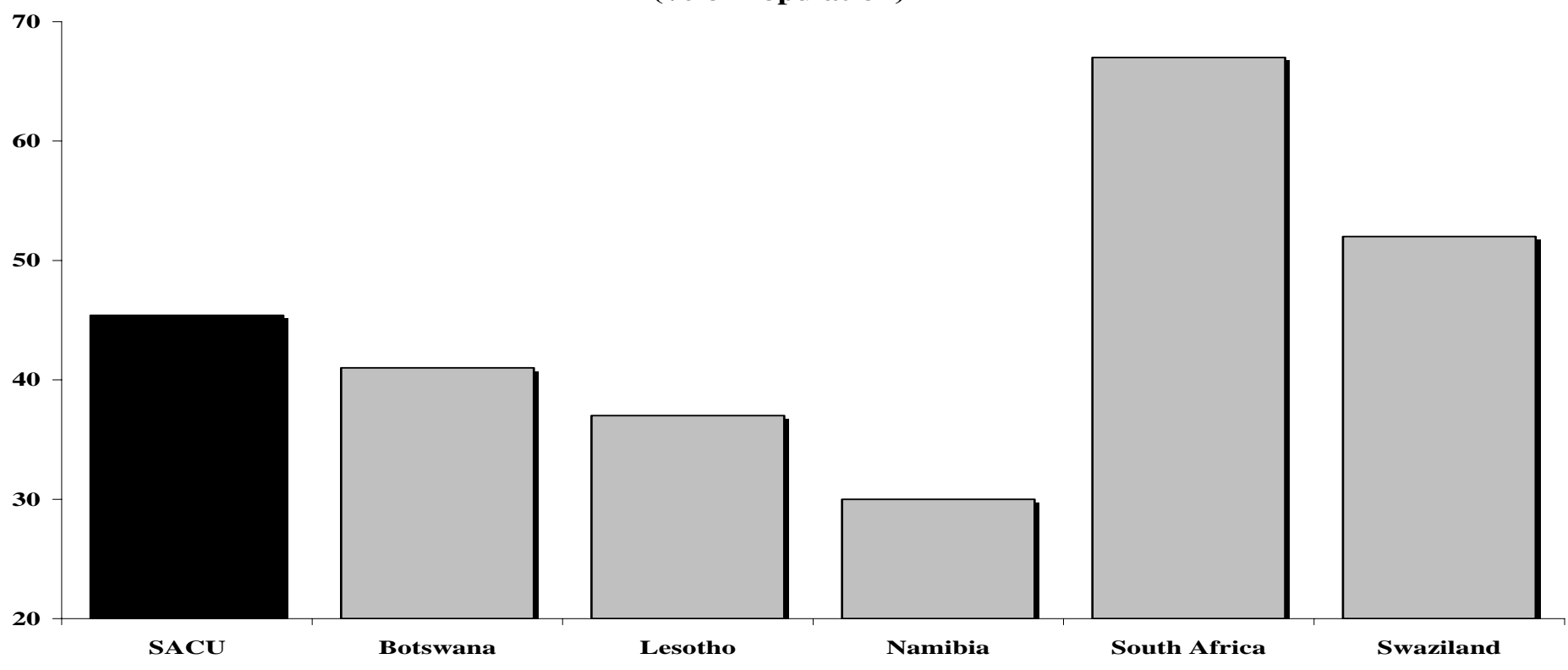

\section{INFORMATION AND COMMUNICATIONS TECHNOLOGY (ICT): AN OVERALL ASSESSMENT FOR SACU}

Access. In terms of mainline teledensity, the SACU region average scores significantly better than SSA and low-income country average, but it is significantly behind upper and lower-middle-income comparators, albeit less so in cellular teledensity. There are only 62 telephone subscribers per 1,000 people in the SACU region compared to 261 in upper-middleincome countries and 126 in lower-middle-income group. The SACU average is double the penetration for low-income and SSA. In terms of cellular teledensity, there are 182/1000 subscribers in SACU region compared to 381 in upper-middle-income countries and 179 in lower-middle-income countries. Not surprisingly, South Africa has the highest penetration of both mainline and cellular telephony in the SACU region, followed by Botswana and Namibia. 
With the gradual technological shift towards cellular telephony now underway, however, SACU countries may "leapfrog" from fixed line to cellular telephony in the near future, leaving behind the low mainline teledensity — and appropriately so.

Affordability-pricing. A 3-minute local call in U.S. cents is one of the most expensive in the world in the SACU region at 10 cents, largely driven by 15 cents in South Africa and 22 cents in Lesotho. In contrast, the cost of a 3-minute call to the US is the lowest among the comparable groups. It costs 265 cents in the SACU region, which is almost half the lowincome and SSA region and much lower than in the middle-income group. The picture is similar when one looks at the cost of three off-peak minute cellular local call which costs 30 cents, compared to 54 cents in upper middle income countries and 42 cents in SSA. South Africa and Namibia have the cheapest rates in the region with Swaziland and Botswana having the most expensive cellular rates.

Quality-technical. The SACU average records more than twice as many faults as uppermiddle-income countries is more in line with low-income and SSA average. Reported faults per 100 telephone mainlines (per year) are very high in the SACU region (54), with Lesotho (75) having the worst record and Botswana (37) being the best performer in the region.

Quality-perception. In spite of the SACU region's relatively poor showing in most of the categories in the ICT sector, commercial perceptions are more closely aliened to the better performing middle-income countries. Commercial perception of telephone infrastructures gets a rating of 4.9 compared to 5.6 in upper-middle-income countries and 4.9 in lower-middle-income countries, while perception of availability of mobile telephone is even better at 6 which is matched by upper-middle-income countries and slightly higher than lowermiddle-income countries. Situation is also same in terms of commercial perception of postal efficiency with the SACU region having a rating of 4.2 compared to 4.4 for upper-middleincome and 3.5 for lower-middle-income group. Commercial perceptions in SSA and lowincome countries were ranked lower than SACU across the board. 
Table 3: Benchmarking of SACU's Performance in the ICT Sector

\begin{tabular}{|c|c|c|c|c|c|c|c|c|c|c|}
\hline ICT & SACU & Botswana & Lesotho & Namibia & $\begin{array}{l}\text { South } \\
\text { Africa }\end{array}$ & Swaziland & $\begin{array}{l}\text { Upper } \\
\text { Middle } \\
\text { Income }\end{array}$ & $\begin{array}{l}\text { Lower } \\
\text { Middle } \\
\text { Income }\end{array}$ & $\begin{array}{l}\text { Low } \\
\text { Income }\end{array}$ & SSA \\
\hline $\begin{array}{l}\text { Teledensity } \\
\text { (total telephone subscribers/1000 people) }\end{array}$ & 231 & 372 & 63 & 182 & 408 & 129 & 635 & 301 & 64 & 99 \\
\hline $\begin{array}{l}\text { Mainlines Teledensity } \\
\text { (mainlines subscribers/1000 people) }\end{array}$ & 62 & 75 & 16 & 66 & 107 & 44 & 261 & 126 & 29 & 31 \\
\hline $\begin{array}{l}\text { Cellular Teledensity } \\
\text { (cellular subscribers/1000 people) }\end{array}$ & 182 & 297 & 47 & 116 & 364 & 84 & 381 & 179 & 37 & 73 \\
\hline $\begin{array}{l}\text { Households with Own Telephone } \\
(\% \text { of households })\end{array}$ & 28 & .. & ." & . & 28 & .. & 13 & 31 & 6 & 4 \\
\hline $\begin{array}{l}\text { Cost of Local Phone Call } \\
\text { (US' cents } / 3 \text { minutes) }\end{array}$ & 10 & 2 & 22 & 4 & 15 & 5 & 9 & 6 & 8 & 10 \\
\hline $\begin{array}{l}\text { Cost of Phone Call to the US } \\
\text { (US' cents } / 3 \text { minutes) }\end{array}$ & 265 & 364 & 231 & 428 & 58 & 242 & 305 & 314 & 504 & 497 \\
\hline $\begin{array}{l}\text { Cost of Cellular Local Call } \\
\text { (US' cents/3 off-peak minutes) }\end{array}$ & 30 & 33 & 26 & 30 & 25 & 34 & 54 & 44 & 40 & 42 \\
\hline $\begin{array}{l}\text { Commercial Perception of Telephone/Fax Infrastructure } \\
\text { quality (l=worst } 7=\text { best })\end{array}$ & 4.9 & 4.6 & .. & 5.1 & 5.1 & .. & 5.6 & 4.9 & 3.4 & 4.3 \\
\hline $\begin{array}{l}\text { Commercial Perception of Availability of Mobile or Cellular } \\
\text { Telephone } \quad \text { (l=worst } 7=\text { best })\end{array}$ & 6.0 & 5.7 & .. & 5.9 & 6.3 & .. & 6.0 & 5.8 & 5.0 & 5.7 \\
\hline $\begin{array}{l}\text { Commercial Perception of Internet Access in Schools } \\
\text { (l=worst 7=best) }\end{array}$ & 3.7 & 4.2 & .. & 3.4 & 3.6 & .. & 3.8 & 3.0 & 2.1 & 2.8 \\
\hline $\begin{array}{l}\text { Commercial Perception of Postal Efficiency } \\
\text { (l=worst 7=best) }\end{array}$ & 4.2 & 5.2 & .. & 4.1 & 3.3 & . & 4.4 & 3.5 & 3.1 & 3.7 \\
\hline $\begin{array}{l}\text { Phone Faults } \\
\text { (reported faults/100 mainlines) }\end{array}$ & 54 & 37 & 75 & 40 & 48 & 70 & 18 & 33 & 64 & 57 \\
\hline $\begin{array}{l}\text { Unmet Demand } \\
(\% \text { of main telephone lines in operation) }\end{array}$ & 29 & 19 & 73 & 2 & 1 & 49 & 4 & 20 & 47 & 50 \\
\hline
\end{tabular}

Note: Data used is from the latest observation available between 1997 and 2003.

Source: Estache,Antonio and Ana Goicoechea (2005). "A 'Research' Datahase on Infrastructure Economic Performance," Policy Research Paper No. 3643, Infrastructure Network, Office of the Vice President, June 2005. 
Figure 4: Teledensity

(total telephone subscribers/1000 people)

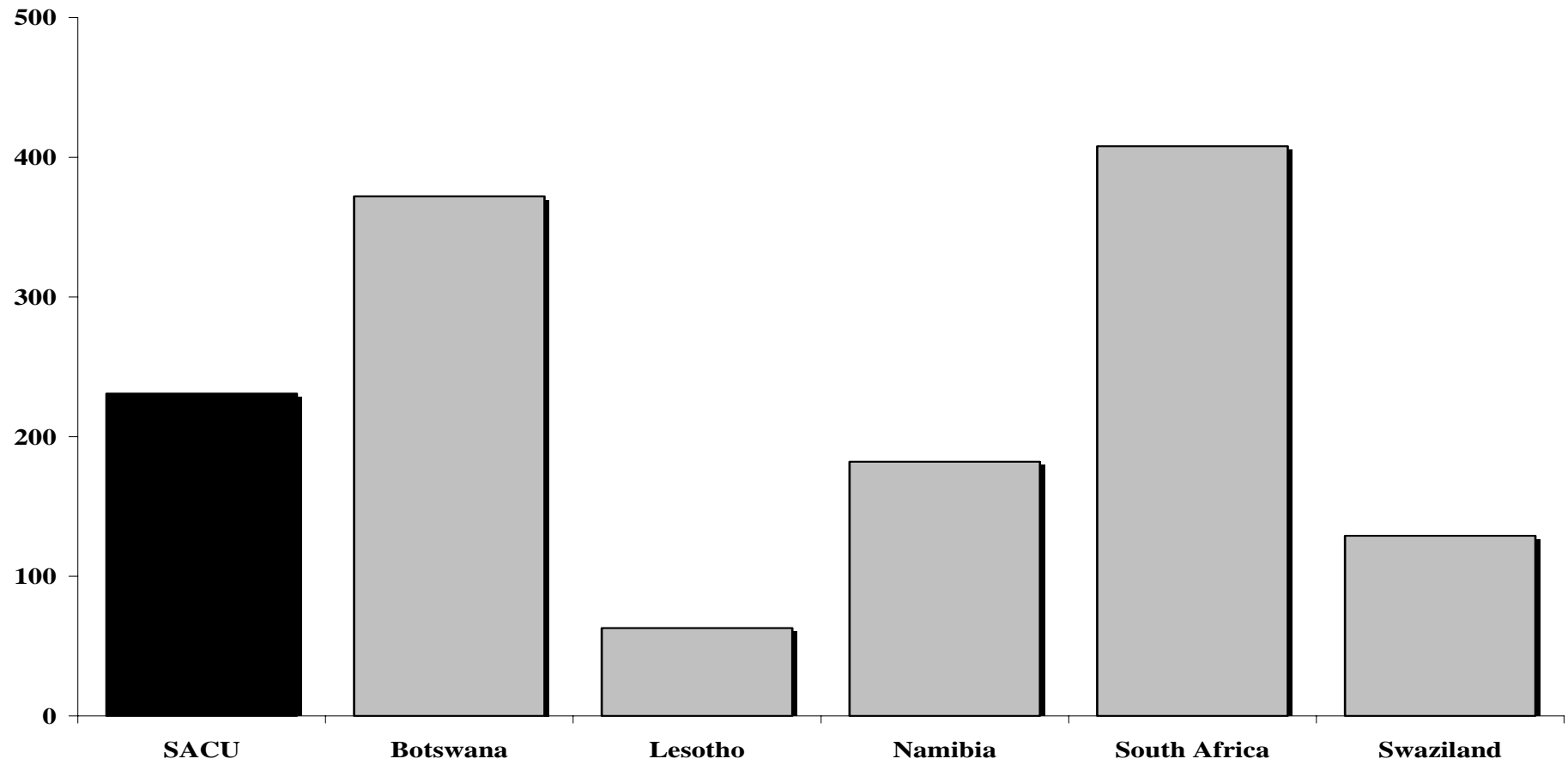

Figure 5: Phone Faults

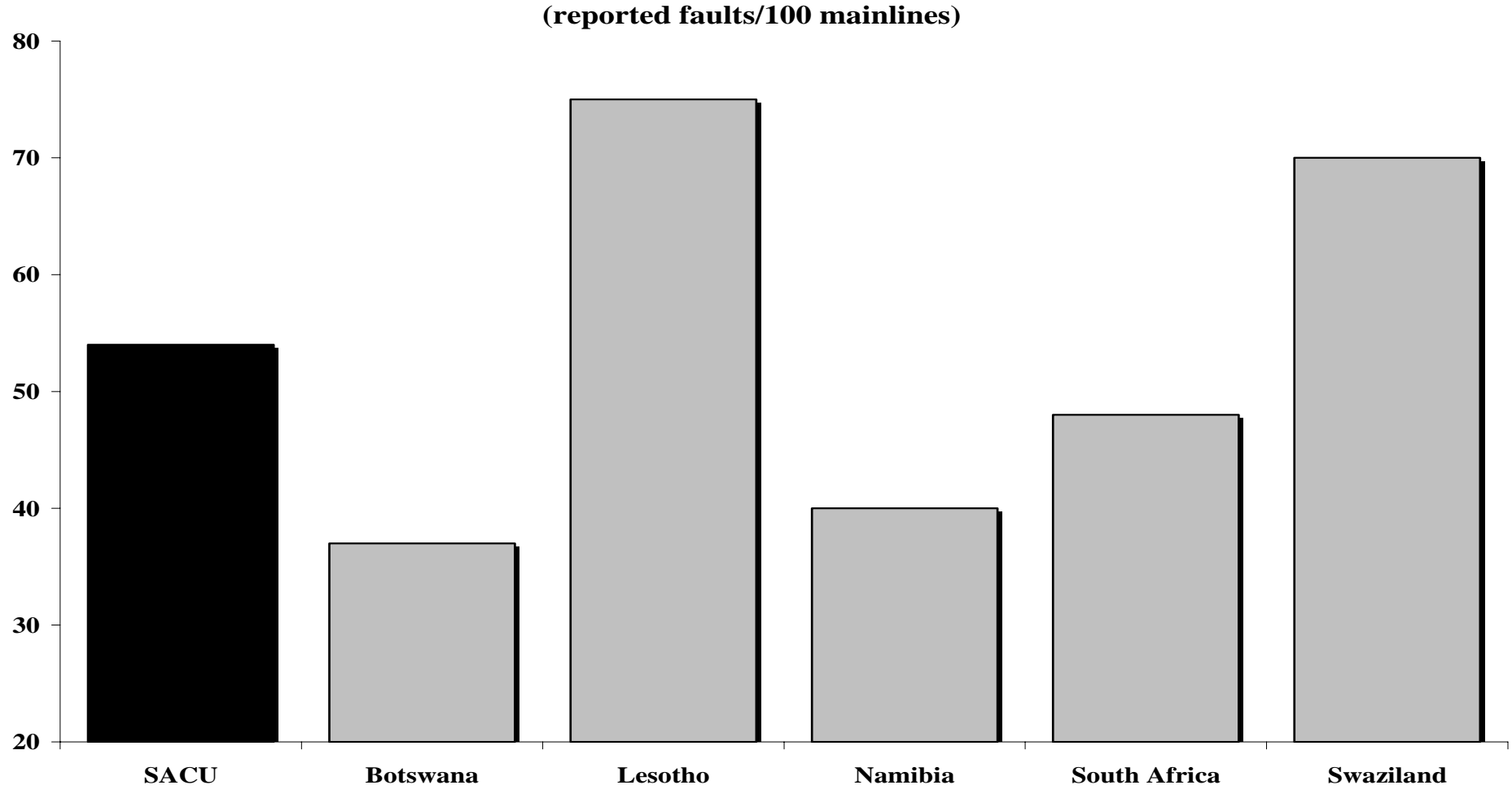




\section{Transport: AN OVERALl AsSESSMENT FOR SACU COUNTRIES}

Access - Road density in terms of population (road-kilometers per 1,000 people) in the SACU region is slightly lower than upper-middle-income countries, but significantly higher than lower-middle-income and more than double the low-income and SSA averages. The SACU region has a density of 8 road-km per 1,000 people compared to 4.9 in lower-middle-income countries. Within SACU, Namibia has the highest road density at 21.3 road-km per 1,000 people with the smaller counties, Lesotho and Swaziland, having the lowest density of around 3 road-km per 1,000 people. In contrast, road density in terms of land is very low in the SACU region when compared to the four comparators. The SACU region has 135 road-km per 1,000 sq km, compared to 1,076 for upper-middle-income countries and 156 for SSA. Not surprisingly, the larger countries, Botswana and Namibia, have the lowest density with Swaziland and Lesotho having road density of around 200 road-km per 1,000 sq km.

Quality-technical. The SACU region has the lowest percentage of paved roads at 27 percent when compared to the other income groups and only manages to slightly outperform SSA average in this category, but this may partly reflect the region's geography and its spatial distribution of the population. Upper-middle-income average is almost twice the SACU average. Within the SACU region, Botswana has the highest percentage of paved roads at 55 percent, with Namibia having the worst at 13 percent. This indicator, however, must be taken with caution and supplemented with other indicators of road quality, which are unfortunately not uniformly available for large number of countries. For example, the SACU region's largely semi-arid climate may require a lower percentage of paved roads than in a rainier climate, and the quality of unpaved roads may be better, perhaps significantly so, than in an average country in the SSA region as a whole.

Quality-perception. The SACU region has one of the shortest travel times to work at 23 minutes when compared to upper-middle-income countries (29 minutes), lower-middleincome countries (40 minutes) and SSA at 34 minutes. Within SACU, South Africa has the longest travel time at 35 minutes compared to 15 minutes for Lesotho. These results must be used with caution because, for this indicator, data are available only for Lesotho, Namibia and South Africa. 
Table 4: Benchmarking of SACU's Performance in the Transport Sector

\begin{tabular}{|c|c|c|c|c|c|c|c|c|c|c|}
\hline Transport & SACU & Botswana & Lesotho & Namibia & $\begin{array}{l}\text { South } \\
\text { Africa }\end{array}$ & Swaziland & $\begin{array}{l}\text { Upper } \\
\text { Middle } \\
\text { Income }\end{array}$ & $\begin{array}{l}\text { Lower } \\
\text { Middle } \\
\text { Income }\end{array}$ & $\begin{array}{l}\text { Low } \\
\text { Income }\end{array}$ & SSA \\
\hline $\begin{array}{l}\text { Road Density in Terms of Population } \\
\text { (road-km/1000 people) }\end{array}$ & 8.0 & 6.2 & 3.4 & 21.3 & 6.1 & 3.0 & 9.2 & 4.9 & 3.0 & 3.3 \\
\hline $\begin{array}{l}\text { Rail Lines Density in Terms of Population } \\
\text { (rail-km/1000 people) }\end{array}$ & 0.8 & .. & .. & 1.23 & 0.44 & .. & 0.51 & 0.30 & 0.13 & 0.18 \\
\hline $\begin{array}{l}\text { Rail Lines Density in Terms of Land } \\
\text { (rail-km/1000 sq km) }\end{array}$ & 9.7 & .. & .. & 2.9 & 16.5 & .. & 31.3 & 15.2 & 9.3 & 3.7 \\
\hline $\begin{array}{l}\text { Commercial Perception of Port Facilities } \\
\text { (l=worst } 7=\text { best) }\end{array}$ & 4.2 & 2.9 & .. & 5.0 & 4.7 & .. & 3.8 & 3.5 & 2.6 & 3.8 \\
\hline $\begin{array}{l}\text { Commercial Perception of Railroad Services } \\
\text { (1=worst 7=best) }\end{array}$ & 4.1 & 4.0 & .. & 4.1 & 4.3 & .. & 2.9 & 2.6 & 2.7 & 3.2 \\
\hline $\begin{array}{l}\text { Commercial Perception of Air Transport Services } \\
\text { (l=worst 7=best) }\end{array}$ & 4.9 & 4.3 & .. & 4.7 & 5.6 & .. & 4.5 & 4.2 & 3.6 & 4.5 \\
\hline $\begin{array}{l}\text { Paved Roads } \\
\text { (\% of total roads) }\end{array}$ & 27 & 55 & 18 & 13 & 21 & .. & 57 & 47 & 30 & 25 \\
\hline
\end{tabular}

Note: Data used is from the latest observation available between 1997 and 2003.

Source: Estache, Antonio and Ana Goicoechea (2005). "A 'Research' Datahase on Infrastructure Economic Perforntance," Policy Research Paper No.3643, Infrastructure Network, 0ffice of the Vice President, June 2005.

Figure 6: Road Density in Terms of Population

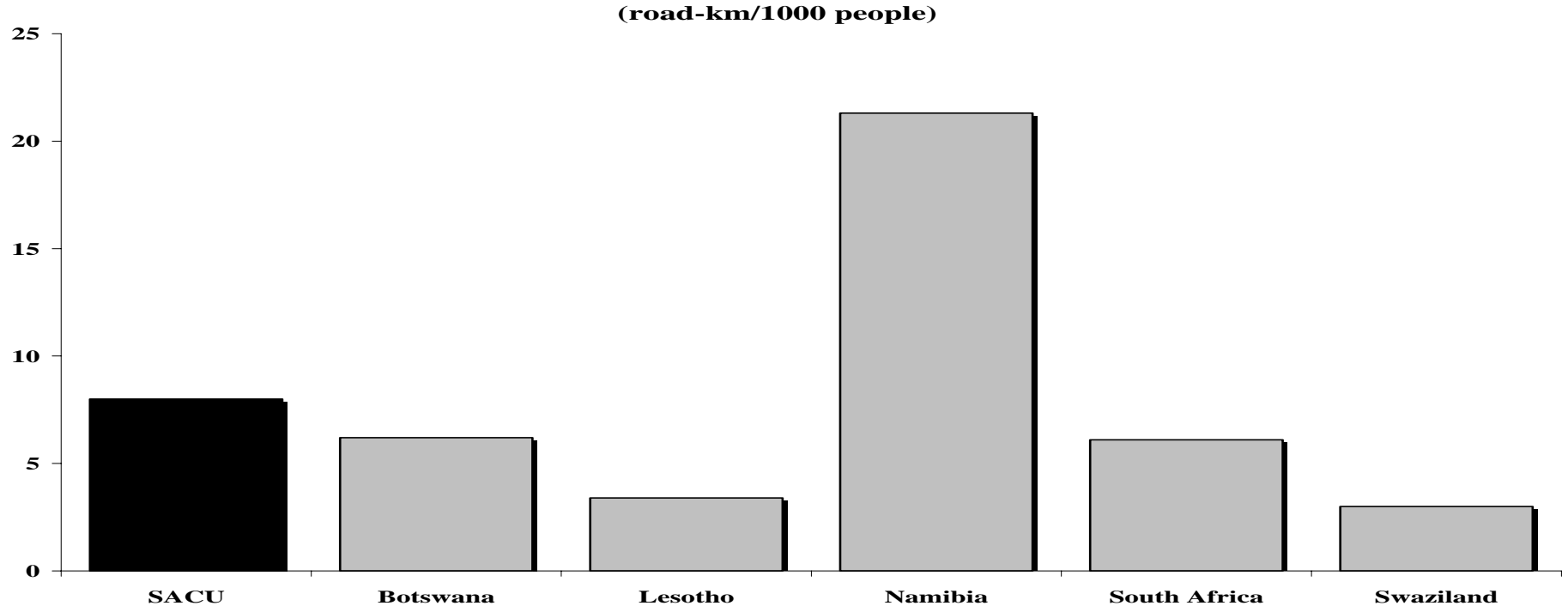




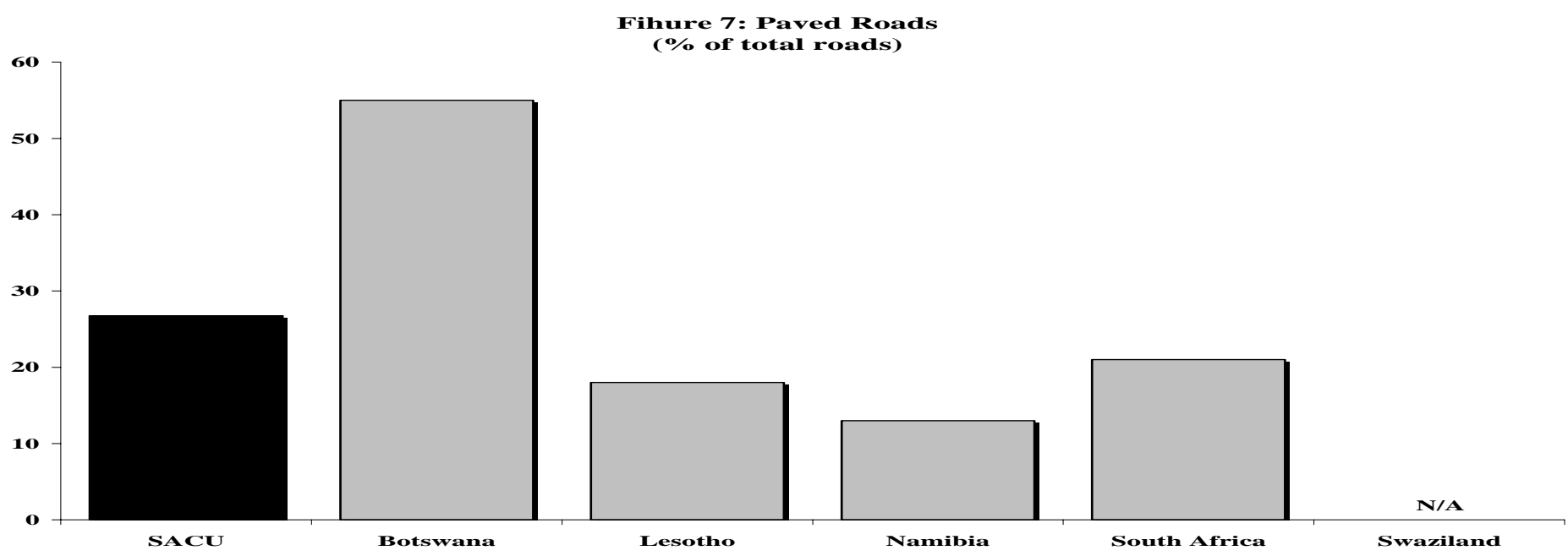

\section{REFLECTIONS ON REgIONAL INTEGRATION AND REgIONAL INFRASTRUCTURE POLICY}

The above synthesis shows (and individual country case studies strongly suggest) that there are significant infrastructure shortfalls in SACU countries in several major indicators of access to basic infrastructure services (electricity, water \& sanitation, ICT, and transport). Performance in Swaziland and Lesotho lags particularly behind their comparator group of countries. But even in South Africa, despite major gains in recent years in expanding access to electricity to the previously unserviced areas, further extension of access to poor areas is very much needed.

But how SACU countries decide to go about meeting these comparative shortfalls in infrastructure performance (especially access) - within purely national or wider, regional frameworks-matters for the success of their infrastructure scale-up efforts. At one extreme, each country could seek to meet this challenge from the narrow view point of its own "national" interest that may include elements of energy security, self-reliance, etc. But this approach may be costly, not only from the point of view of the smaller SACU members but also for South Africa that is increasingly looking to expand its economic, trade, and transportation links into the rest of the broader African continent. At the other extreme, therefore, the SACU countries may be seen as an integrated economic, not only customs, space featuring potentially lower trade, transportation and transaction costs within the region and also vis-à-vis other neighboring countries with significant geographic links (e.g., Mozambique).

Moreover, there is evidence of an increasingly tight supply-demand balance for basic infrastructure services in the SACU region (e.g., electricity, telecom, and transport and water and sanitation) so that infrastructure is becoming a binding constraint for growth. In South Africa, for example, recent forecasts of demand for electricity and telecom and associated investment needs in an accelerated growth scenario suggest annual requirements of the order of $\$ 5$ billion in just these two sectors. In Botswana (World Bank and BIDPA 2005c), Lesotho (World Bank 2005b) and Swaziland (World Bank 2006), in particular, there is also a growing recognition of infrastructure deficiencies and their potential impact on growth.

The basic geographic and economic structure of SACU-with one very large economy (South Africa) and four small states-suggests considerable benefits from greater 
infrastructure connectivity and market integration, especially for the smaller, landlocked members. For smaller economies, it is not the level of the infrastructure capital stock per se that matters as much as its connectivity to their wider economic areas. Lesotho and Swaziland are already substantially integrated into the wider South African economy, and Botswana's largest concentration of the population and economic activity lies close to the South African border. There are also large movements of labor across borders, and remittances from South Africa are important source of income in Swaziland, Lesotho and Botswana. Moreover, recent research has demonstrated significant geographic and infrastructure related disadvantages of landlockedness in Africa (Collier and O'Connell 2004; Limao and Venables 2001). ${ }^{5}$ As a result, further reduction in the costs of the "border effect", in part associated with still not fully exploited infrastructure connectivity and market integration in SACU, seems warranted (Ndulu 2006).

Effective infrastructure connectivity and market integration in the SACU is likely to require mobilization of both private and public sector resources. While key infrastructure sectors in the region remain in public sector hands, there is scope for greater private participation in infrastructure (PPI), which has so far been limited in Africa. Given the large investment requirements of the scale up efforts, PPI is likely to be an attractive financing option, especially for smaller SACU states. The Government of Botswana, for example, has already identified toll roads, power generation, railways and telecommunications as the main areas for potential private investment. Botswana's Privatization Master Plan was approved in March 2005 aiming to eventually privatize most of the major utilities (World Bank 2006b). The experience of East Asia is also instructive in this regard. In that region, cross-border integration was private sector, market-driven process of emergence of regional production networks; it is these production networks that contributed significantly to greater regional infrastructure connectivity in East Asia (Kuroda 2006).

Finally, there are important, successful examples of regional projects that significantly facilitated transport, trade, and investment in the broader region. These multi-country projects demonstrate the feasibility and potential benefits of infrastructure connectivity on regional integration in the SACU. Once in place, such regional projects may also prove more resilient to various national economic shocks that individual countries may be subject to and would affect more directly local projects. These include the following (Kritzinger van Niekerk, Ndulu and Reinikka 2006):

- Lesotho Highlands Project

- Southern Africa Power Pool

- South Africa-Maputo Toll Road

- Transit facilitation projects, e.g. Trans-Kalahari Corridor

With this broad summary of SACU-wide findings in mind, we now turn to in-depth benchmarking of infrastructure performance in individual SACU countries: South Africa, Botswana, Lesotho, Namibia and Swaziland.

\footnotetext{
${ }^{5}$ Limao and Venables (2001), for example, estimate that landlocked countries, on average, face 50 percent higher transport costs and about equally lower trade volumes in coastal economies, but landlocked countries are able to offset these costs significantly by building better infrastructure and connectivity to the coastal areas.
} 


\section{SOUTH AFricA}

The international benchmarking of infrastructure performance in South Africa presented in this section draws almost entirely on a recent exercise for South Africa by Bogetić and Fedderke (2006b). For South Africa, we use from the aforementioned data base the available indicators for electricity (7), water \& sanitation (4), and most of the broader group of indicators for information communication technology (13) and transport (10). For our purpose, this country's benchmarking is limited to sector performance indicators. Detailed benchmarking is presented in Tables 1-4. We do not use nor discuss institutional reform indicators that are also available in the database, and are subject of a separate exercise. In the following discussion, we focus on some of the most important conclusions.

\section{Energy—electricity}

Overall assessment. Overall, despite important gains in recent years, South Africa's performance in the electricity sector (measured by the seven indicators discussed below) compared to the upper-middle-income country benchmark is relatively weak in terms of access, but favorable in terms of technical efficiency (i.e., percentage of losses), pricing, and perceptions of service. Since 1994, a significant area of policy success has been to increase service access, but the level remains behind the average expectation for upper middle-income countries. Low aggregate losses reflect solid internal technical efficiency of the electricity network, but this hides the problem of occasional outages in specific areas, even in large cities such as Johannesburg. Low prices reflect the comparatively low cost of South Africa's electricity (produced almost exclusively from coal) and the fact that a good part of the capital stock has already been depreciated as there has been little investment in the sector over the past two decades. ${ }^{6}$ Finally, local perceptions of service have been rather favorable, but this may have reflected a selection bias in that only customers that do have service provision responded to this question. The overall picture, therefore, suggests that despite recent gains, the main weakness in South Africa's electricity sector lies in access, which remains limited, particularly in terms of service delivery to the poor (Table 1 and Figures 1-2).

Access. Not surprisingly, South Africa's access to the electricity network is superior to the rest of Sub-Saharan Africa (SSA) with $66 \%$ of the population having access, compared to $15 \%$ for region as a whole. ${ }^{7}$ Access has also risen substantially in South Africa, from some $30 \%$ ten years ago reflecting the success to date of the policy of widening access to the electricity network. Nevertheless, South Africa's level of overall access remains significantly behind - by about a third - its own income group of uppermiddle-income countries (87\%). A related (and corroborating) statistic focusing on households indicates that about $65 \%$ of all households in South Africa report having access to electricity compared to $23 \%$ for the SSA region and $74 \%$ upper-middleincome countries. Compared with other regions of the world, South Africa performs better than South Asia and East Asia Pacific.

\footnotetext{
${ }^{6}$ With significant new investments being planned by ESKOM over the coming years, prices are likely to increase.

${ }^{7}$ The database observation for South Africa is from 2002. More recent country data suggests an access rate of $70 \%$ (UNDP/WorldBank 2005), but the overall conclusion remains the same.
} 
Affordability—pricing. South African average end-user prices (US cents/kwh) are one of the cheapest in the world at 3 cents for residential and 2 cents for non-residential customers. By comparison, these user prices in upper-middle-income countries are, on average, about 9 and 7 cents, respectively, while SSA rates are 6 and 5 cents. The world average is 9 cents for residential customers and 6 cents for non-residential customers. In South Africa, the low user prices do not seem to reflect obvious, overall underpricing, as is the case in many developing countries with the attendant quasi-fiscal losses. Instead, it is a consequence of the low cost structure of what is considered a well-run state electricity company (ESKOM) and the fact that part of the capital stock has already been depreciated as there has been little investment in the sector over the past two decades; hence, the fixed cost component of the electricity cost/price in South Africa is very low. ${ }^{8}$

Quality-technical. Measured by the percentage of aggregate transmission and distribution losses, technical efficiency of the electricity sector is strong. Electric power transmission and distribution losses account for $8 \%$ of total output in South Africa, which outperforms both SSA (19\%) and upper-middle-income countries (14\%). Indeed, this aggregate performance is more comparable to the high-income group of OECD countries $(6 \%)$. However, this aggregate picture must be qualified: for the $30 \%$ of the population not having access, this aggregate technical efficiency does not matter. In addition the increased prevalence of power outages in specific communities, even within Johannesburg, associated with the poor maintenance and the state of the distribution network under the control of local governments further qualifies the technical efficiency of the distribution network. ${ }^{9}$

Quality-perceptions. In terms of commercial perception of electricity service, South Africa ranks amongst the best with a 5.8 rating out of 7 ( $7=$ best, $1=$ =worst). This compares favorably with high income OECD countries (6.3) and is higher than upper middle income countries (5.2). South Africa also performs well on commercial perception of the public agency electricity provider with a ranking of 6 out of 7 . This ranking is only matched by Middle East and North Africa (MENA) and is higher than upper-middle-income (5.3) and high-income OECD (5.3). As noted above, however, this may reflect a selection bias in that only customers with access to service would normally respond to this question. In that sense, the indicators of the lack of access (about $34 \%$ of the population) and the generally favorable perceptions of service cover essentially different segments of the population.

8 However, this static picture is going to change soon. The South African rates are likely to increase over the coming years as the electricity company, ESKOM, implements its major investment upgrading program aimed at rehabilitating and expanding its existing capacity and the distribution network. Part of the financing of this investment program will need to come from increased rates to accommodate higher fixed costs arising from the new investments. When it comes to pricing, this will require careful thought to the rebalancing/design of tariffs to balance the objectives of access, efficiency, revenue and affordability.

${ }^{9}$ In South Africa, about half of the distribution network is under the control of the main utility ESKOM, and the rest is under the control of local governments. Since the local governments face major expenditure pressures against limited revenue sources available, maintenance of their electricity distribution network has often been inadequate. 
Table 1: Benchmarking of South Africa's Performance in the Energy Sector

\begin{tabular}{|c|c|c|c|c|c|c|c|c|c|c|c|c|}
\hline Energy & $\begin{array}{l}\text { South } \\
\text { Africa }\end{array}$ & $\begin{array}{c}\text { Upper } \\
\text { Middle } \\
\text { Income }\end{array}$ & SSA & $\begin{array}{c}\text { Middle } \\
\text { East } \\
\text { and } \\
\text { Noth } \\
\text { Africa } \\
\end{array}$ & $\begin{array}{l}\text { South } \\
\text { Asia }\end{array}$ & $\begin{array}{c}\text { East } \\
\text { Asia } \\
\text { Pacific }\end{array}$ & $\begin{array}{c}\text { Latin } \\
\text { America } \\
\& \\
\text { Caribbean }\end{array}$ & $\begin{array}{c}\text { Europe } \\
\& \\
\text { Central } \\
\text { Asia }\end{array}$ & $\begin{array}{l}\text { Low } \\
\text { Income }\end{array}$ & $\begin{array}{l}\text { Middle } \\
\text { Income }\end{array}$ & $\begin{array}{l}\text { High } \\
\text { Income } \\
\text { OECD }\end{array}$ & World \\
\hline $\begin{array}{l}\text { Access to Electricity Network } \\
(\% \text { of Population) }\end{array}$ & 66 & 87 & 15 & 88 & 31 & 54 & 79 & 99 & 31 & 85 & .. & 60 \\
\hline $\begin{array}{l}\text { Households Reporting Access to Electricity } \\
\text { ( } \% \text { of households) }\end{array}$ & 65 & 74 & 23 & 80 & 39 & 62 & 72 & 99 & 32 & 79 & .. & 45 \\
\hline $\begin{array}{l}\text { Energy Use Per PPP GDP } \\
\text { (kg of oil equivalent/1000 PPP dollars, Constant 2000) }\end{array}$ & 257 & 249 & 364 & 249 & 184 & 212 & 207 & 375 & 374 & 246 & 188 & 275 \\
\hline $\begin{array}{l}\text { Electricity Average End-User Prices (US cents/kWh) - } \\
\text { (Residential/Non-Residential) }\end{array}$ & $3 / 2$ & $9 / 7$ & $6 / 5$ & .. & .. & $5 / 5$ & $10 / 8$ & $6 / 6$ & $6 / 6$ & $8 / 7$ & $13 / 6$ & $9 / 6$ \\
\hline $\begin{array}{l}\text { Commercial Perception of Electricity service } \\
(1=\text { worst } 7=\text { best })\end{array}$ & 5.8 & 5.2 & 4.3 & 5.1 & 2.6 & 4.3 & 4.2 & 4.8 & 2.8 & 4.7 & 6.3 & 5.0 \\
\hline $\begin{array}{l}\text { Commercial Perception of Public Agency Electricity Provider } \\
\text { (1=worst } 7=\text { best) }\end{array}$ & 6.0 & 5.3 & 4.3 & 6.0 & 3.8 & 5.0 & 4.8 & 4.8 & 4.0 & 5.2 & 5.3 & 4.8 \\
\hline $\begin{array}{l}\text { Electric Power Transmission and Distribution Losses } \\
\text { (\% of total output) }\end{array}$ & 8.0 & 14.0 & 19.0 & 14.0 & 22.0 & 12.0 & 18.0 & 18.0 & 22.0 & 15.0 & 6.0 & 14.0 \\
\hline
\end{tabular}

Note: Data used is from the latest observation available between 1997 and 2003.

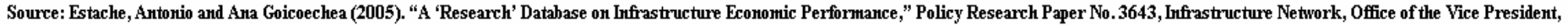
June 2005.
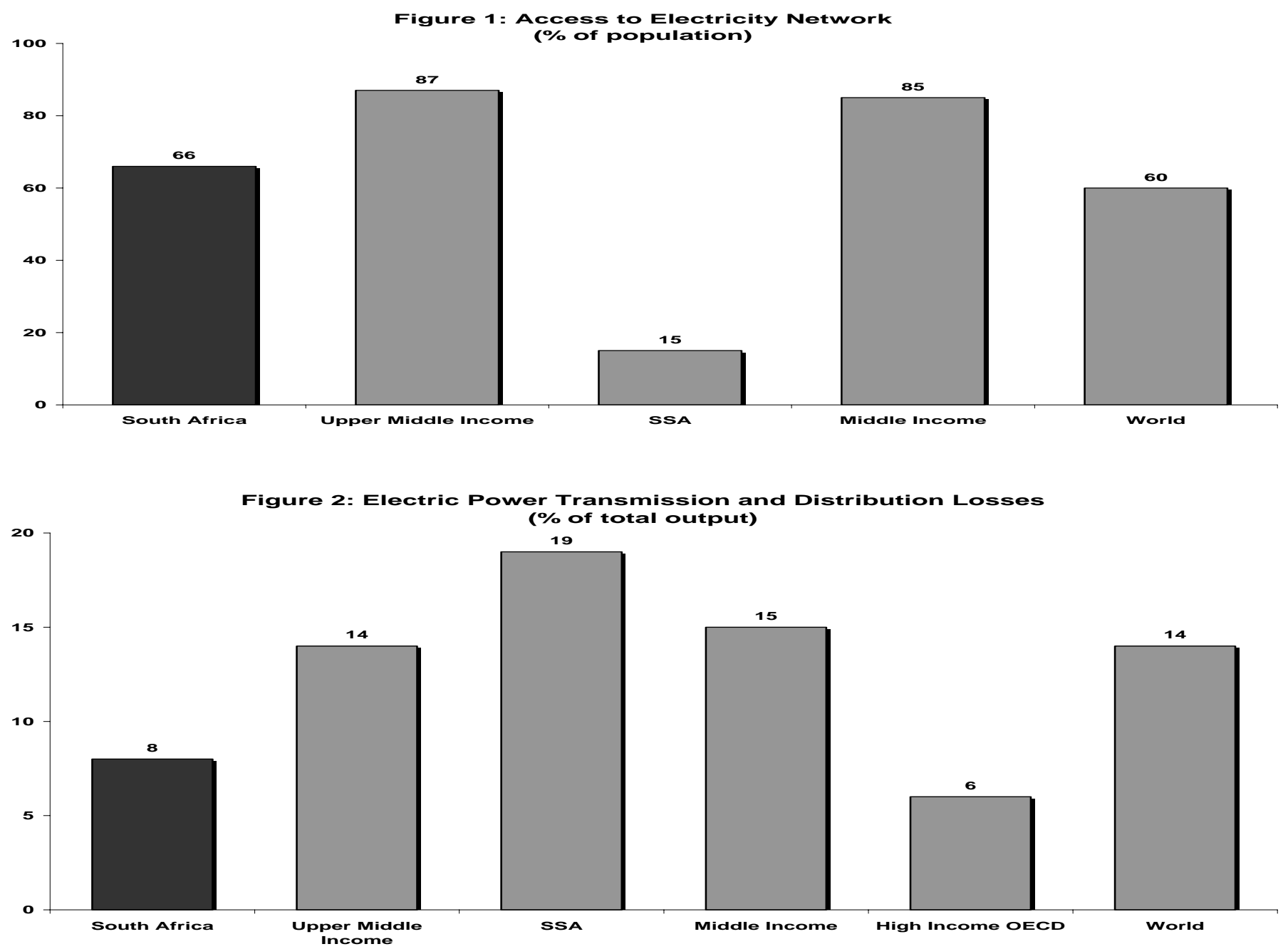


\section{Water \& sanitation}

Overall assessment. Overall, South Africa's performance in access to water lags behind its benchmark upper-middle-income group, essentially because of the much lower access in rural areas. This is even more notable with respect to sanitation. In terms of the overall average, the quality of drinking water as measured by the percentage of households using piped or welled water in the aggregate is better than in its benchmark group, but this is because of the very high performance on this indicator in urban areas. (The database does not have information on affordability/pricing).

By contrast, rural households score lower than the benchmark and also lower than almost all world regions, including Sub-Saharan Africa. Apparently, while access and quality do not appear to be major problems in urban areas, the performance in these dimensions in rural areas lags seriously behind most comparator groups. This favorable urban picture should also be qualified by the fact that in South Africa, some communities in urban areas, referred to as "peri-urban" areas (e.g., parts of Soweto, Diepsloot etc.) that may or may not belong formally or statistically to their larger urban agglomerations, often lack quantity and quality of basic service, such as water and sanitation (Table 2 and Figures 3-4).

Access. Overall access to water is below the benchmark upper-middle-income countries, because of the significantly lower access in rural areas. Specifically, population with access to improved water is $87 \%$, which is significantly higher than SSA (64\%) but lags behind upper-middle-income countries (93\%). South Africa compares well to the broader group of middle-income countries (both lower and uppermiddle income) (89\%), but is noticeably below high-income OECD (99\%). However, looking at the rural/urban differences, rural South Africa (73\%) lags far behind the upper-middle-income rural average (85\%), while South African urban areas $(98 \%)$ do better than other upper-middle-income countries (96\%). About $67 \%$ of the population has access to improved sanitation, which is almost twice the SSA level and slightly above the world average (64\%). However it is still far behind upper-middle-income countries $(86 \%)$ and high-income OECD countries $(100 \%)$.

Quality-technical. The percentage of households using piped or welled water as main source of drinking water is 85 for South Africa, which is higher than in upper-middleincome group (82\%), East Asia and Pacific $(80 \%)$, and SSA $(78 \%)$, but below both Middle East \& North Africa (89\%) and South Asia (89\%). Once again, however, this figure masks a stark contrast between urban and rural areas. The share of rural households in South Africa using piped or welled water as main source of drinking water is only $65 \%$ compared to $98 \%$ for urban areas. Significantly, the rural area percentage for South Africa is lower than the comparable rural household percentages in all the world regions, including SSA (71\%), except for East Asia \& Pacific and Latin America \& the Caribbean which have very similar performance (64\% each); the latter is the region that has been documented as having a significant backlog of infrastructure deficiencies that, inter alia, contributed to its low growth (Leipziger, 2001). By contrast, South Africa's performance on this indicator in urban areas (98\%) is the highest (together with South Asia) among all world regions and low and middle-incomecountries. 
Quality-perception. At 5.7 out of 7, South Africa gets one of the highest ratings in commercial perception of water service. The rating for high-income OECD countries is 5.2 and SSA (4.2). Again, this may represent the view of the satisfaction with service by the segments of the population already enjoying access. Also, it may reflect the "urban bias" of the perception indicator, and may hide differences between the quality of service in urban versus rural communities (see section on urban-rural divide below).

Table 2: Benchmarking of South Africa's Performance in the Water \& Sanitation

\begin{tabular}{|c|c|c|c|c|c|c|c|c|c|c|c|c|}
\hline$\underline{\text { Water }}$ & $\begin{array}{l}\text { South } \\
\text { Aficica }\end{array}$ & $\begin{array}{l}\text { Upper } \\
\text { Middle } \\
\text { Income }\end{array}$ & SSA & $\begin{array}{c}\text { Middle } \\
\text { East } \\
\text { and } \\
\text { Noth } \\
\text { Afiica }\end{array}$ & $\begin{array}{l}\text { South } \\
\text { Asia }\end{array}$ & $\begin{array}{c}\text { East } \\
\text { Asia } \\
\text { Pacific }\end{array}$ & $\begin{array}{c}\text { Latin } \\
\text { America } \\
\& \\
\text { Caribbean }\end{array}$ & $\begin{array}{c}\text { Europe } \\
\& \\
\text { Central } \\
\text { Asia }\end{array}$ & $\begin{array}{l}\text { Low } \\
\text { Income }\end{array}$ & $\begin{array}{l}\text { Middle } \\
\text { Income }\end{array}$ & $\begin{array}{l}\text { High } \\
\text { Income } \\
\text { OECD }\end{array}$ & World \\
\hline $\begin{array}{l}\text { Access to Improved Water Sources } \\
(\% \text { of population) }\end{array}$ & 87 & 93 & 64 & 85 & 72 & 75 & 90 & 87 & 65 & 89 & 99 & 80 \\
\hline $\begin{array}{l}\text { Access to Improved Sanitation } \\
(\% \text { of population })\end{array}$ & 67 & 86 & 37 & 77 & 48 & 60 & 77 & 78 & 41 & 79 & 100 & 64 \\
\hline $\begin{array}{l}\text { Commercial Perception of Water Service } \\
\text { (l=worst } 7=\text { best })\end{array}$ & 5.7 & 5.0 & 4.2 & 5.6 & 4.1 & 4.8 & 4.7 & 4.6 & 4.0 & 4.9 & 5.2 & 4.7 \\
\hline $\begin{array}{l}\text { Households Using Piped or Well Water as Main Source of } \\
\text { Drinking Water ( } \% \text { of households) }\end{array}$ & 85 & 80 & 78 & 89 & 90 & 74 & 75 & 83 & 78 & 81 & .. & 79 \\
\hline
\end{tabular}

Note: Data used is from the latest observation available between 1997 and $2 \theta \theta 3$.

Source: Estache, Antonio and Ana Goicoechea (2005). "A 'Research' Database on Infrastructure Economic Performance," Policy Research Paper No. 3643, Infrastructure Network, Office of the Vice President, June 2005.

Figure 3: Access to Impoved Water Sources

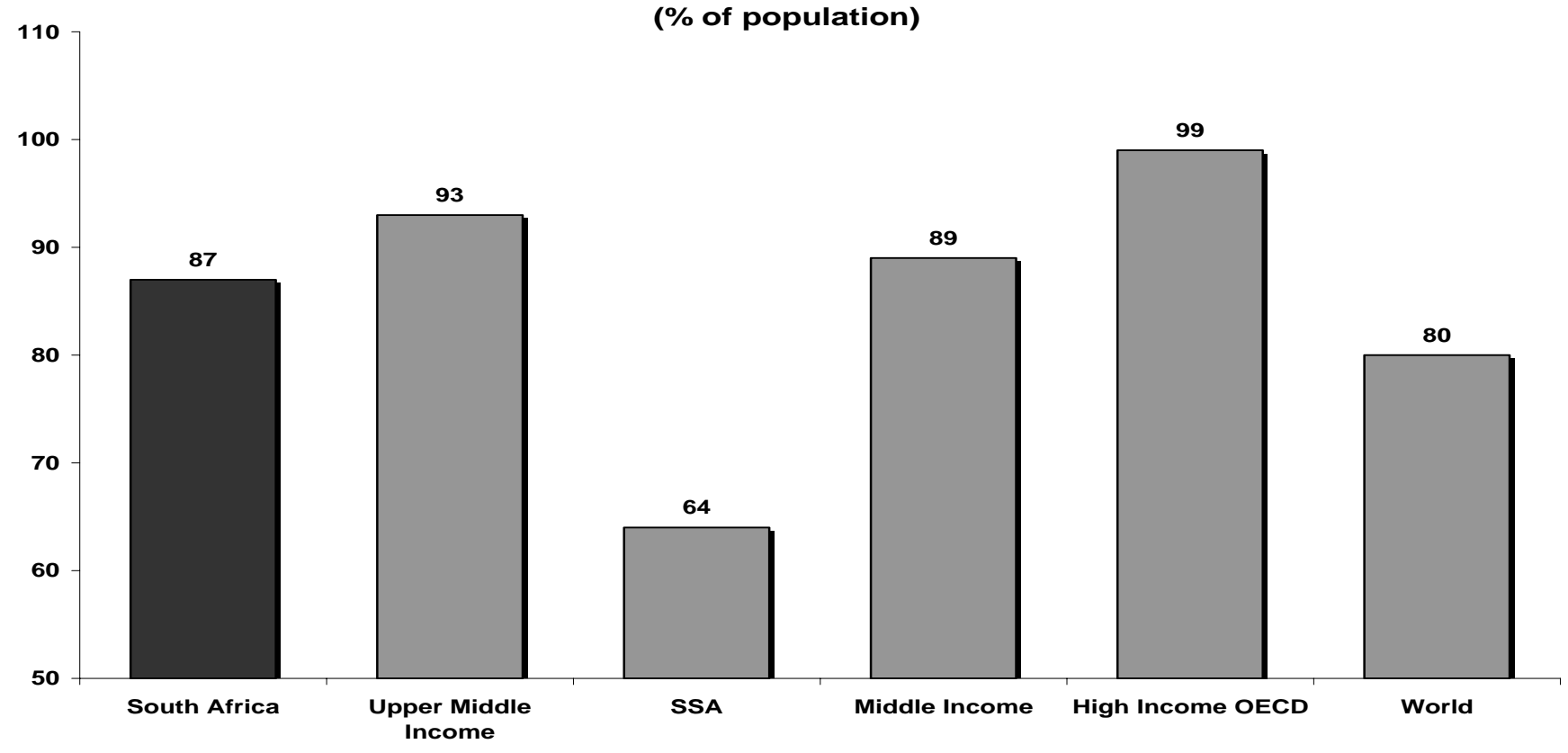




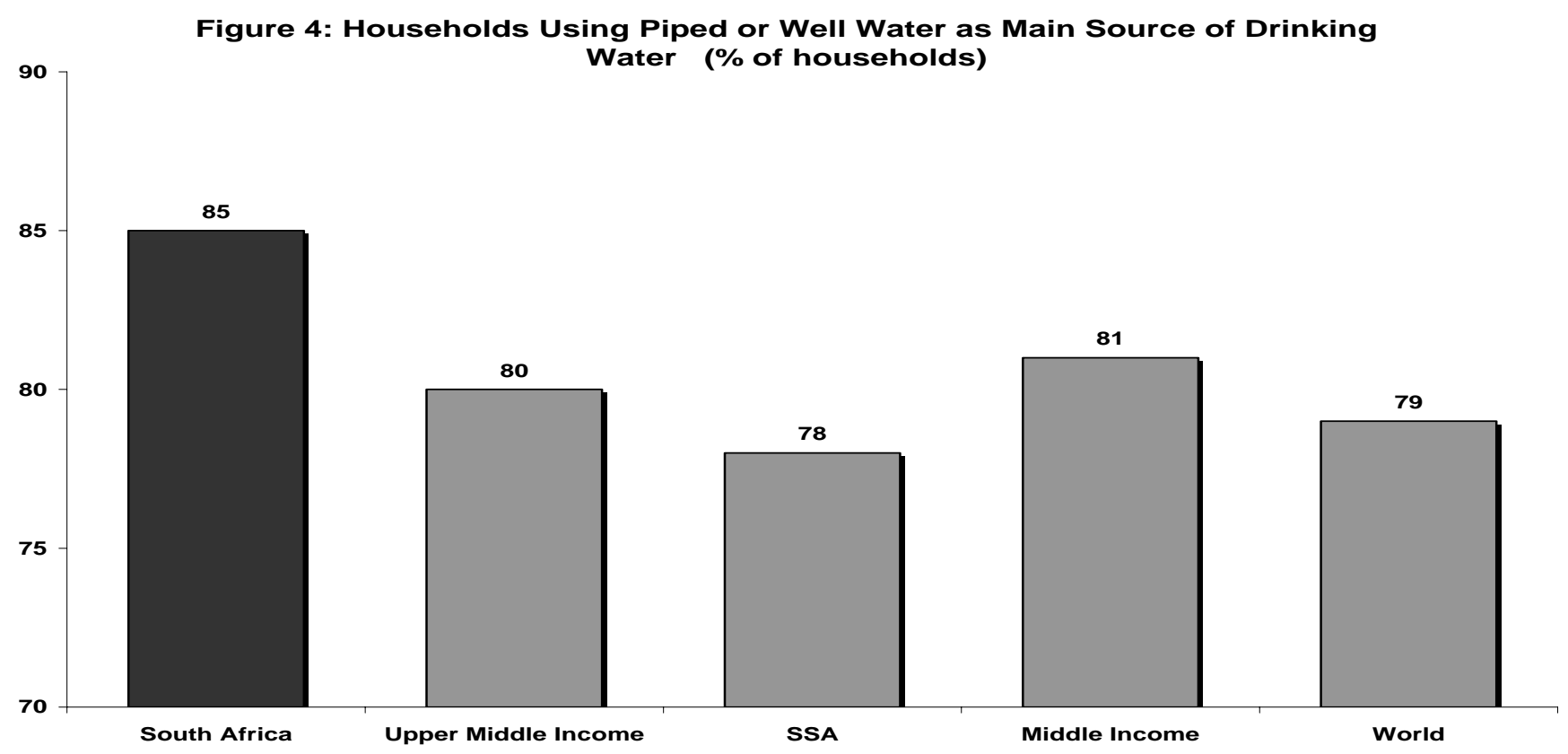

\section{Information and Communications Technology (ICT)}

Overall assessment. In general, the ICT sector in South Africa displays performance akin to that of the energy and water \& sanitation sectors, with some interesting nuances emerging from the pricing of various services. At first glance, the overall indicator of access appears good, but supplementary indicators suggest less than expected quality and major gaps in service delivery, quality and even access in rural areas. For example, on the surface, South African households pay some of the highest local rates in the world, and the low affordability is reflected in low telephone ownership in rural areas. By contrast, off-peak cellular service and international calls to the United States are provided at low, competitive prices, catering largely the wealthier segments of the population. But this has to be qualified. The poor segments of the population may now be effectively by-passing the land-line network, and are switching straight into the cellular network. So the lower rates may not be exclusively benefiting the wealthy. (See the discussion below on the perception of cellular access.) Nevertheless, in the local debate on the cost issue, there are indications that high international prices prevail for calls to many other destinations, and that broadband access is both limited and expensive. ${ }^{10}$ Moreover, quality, as measured by reported faults per year per 100 mainlines, appear surprisingly low for an upper middle-income country (Table 3 and Figures 5-6).

Access. In terms of mainline teledencity, the picture is similar to energy and water whereby South Africa has better penetration than SSA, Middle East \& North Africa, South Asia, and East Asia Pacific countries but lags somewhat behind middle-income countries and Latin America \& the Caribbean. However cellular teledencity is reasonably comparable to upper-middle-income countries though it still lags behind high-income OECD levels. In terms of household ownership of telephones, only $28 \%$ of South African households own a telephone, which is much higher than the uppermiddle-income benchmark of $13 \%$ and comparable figures for SSA and South Asia regions, both at 4\%, and East Asia Pacific (9\%). But it is still a long way from Europe and Central Asia (ECA) at 43\%, suggesting considerable remaining room for growth.

${ }^{10}$ See Truen and Hodge (2005). 
The ownership rates in rural areas, however, are seven times lower $(6 \%)$ than in urban areas (43\%) in South Africa, making the rural rate more comparable to those in entire group of middle-income countries.

Affordability-pricing. A 3-minute local call in U.S. cents is one of the most expensive in the world in South Africa at 15 cents, which is three times the cost in South Asia and East Asia Pacific and equal to the high-income OECD countries. This reflects monopolistic market structures in local services. Local debate in South Africa has also emphasized the high cost structure, including on the international call market segment. Nevertheless, within the cellular and international segment, some calls are very competitive. For example, the database used for this benchmarking shows that in terms of the cost of three off-peak minute cellular local calls (25 cents), South Africa has one of the cheapest rates when compared with upper-middle-income (54 cents) and high-income OECD (59 cents) countries where costs are twice as much. In addition, according to the database (with original data from the ITU-World Telecommunications Development Report) an international, 3-minute, peak rate, fixed line call to the United States in 2001 appeared lower than in upper-middle-income countries and high-income OECD countries, but this needs to be checked against most recent data within the country and a more detailed look at the rate structure before making definitive conclusions.

Quality-technical. Reported faults per 100 telephone mainlines (per year) are very high (48) by upper-middle-income (18) country standards and are closer to the SSA average (57). High income OECD country rates-towards which South Africa may aspire in this highly globalized sector--are more than four times lower (11\%).

Quality-perception. Interestingly, perceptions of ICT are more closely aligned to the other indicators of performance. Commercial perception of telephone infrastructures rating is 5.1 out of 7 compared to 6.6 for high income OECD countries and 5.6 in upper-middle-income countries. Commercial perception of availability of mobile telephones is much higher at 6.3 (vs. 6 for upper-middle-income group), which is only better in high-income OECD at 6.6. Commercial perception of internet access in schools is also low by high income OECD standards, 3.6 vs. 5.4 and slightly lower than upper-middle-income countries (3.8). Commercial perception of postal efficiency is even worse at 3.3 which is only just above the average for low-income countries (3.1), and almost half the rating given to high-income OECD, and compared to 4.4 for uppermiddle-income countries. 
Table 3: Benchmarking of South Africa's Performance in the ICT Sector

\begin{tabular}{|c|c|c|c|c|c|c|c|c|c|c|c|c|}
\hline ICT & $\begin{array}{l}\text { South } \\
\text { Africa }\end{array}$ & $\begin{array}{l}\text { Upper } \\
\text { Middle } \\
\text { Income }\end{array}$ & SSA & $\begin{array}{c}\text { Middle } \\
\text { East } \\
\text { and } \\
\text { Noth } \\
\text { Africa } \\
\end{array}$ & $\begin{array}{l}\text { South } \\
\text { Asia }\end{array}$ & $\begin{array}{c}\text { East } \\
\text { Asia } \\
\text { Pacific }\end{array}$ & $\begin{array}{c}\text { Latin } \\
\text { America } \\
\& \\
\text { Caribbean }\end{array}$ & $\begin{array}{c}\text { Europe } \\
\text { \& } \\
\text { Central } \\
\text { Asia }\end{array}$ & $\begin{array}{l}\text { Low } \\
\text { Income }\end{array}$ & $\begin{array}{l}\text { Middle } \\
\text { Income }\end{array}$ & $\begin{array}{c}\text { High } \\
\text { Income } \\
\text { OECD }\end{array}$ & World \\
\hline $\begin{array}{l}\text { Teledensity } \\
\text { (total telephone subscribers/1000 people) }\end{array}$ & 408 & 635 & 99 & 292 & 72 & 172 & 433 & 547 & 64 & 468 & 1393 & 501 \\
\hline $\begin{array}{l}\text { Mainlines Teledensity } \\
\text { (mainlines subscribers/1000 people) }\end{array}$ & 107 & 261 & 31 & 129 & 35 & 76 & 192 & 224 & 29 & 193 & 572 & 213 \\
\hline $\begin{array}{l}\text { Cellular Teledensity } \\
\text { (cellular subscribers/1000 people) }\end{array}$ & 364 & 381 & 73 & 167 & 37 & 96 & 249 & 325 & 37 & 280 & 827 & 296 \\
\hline $\begin{array}{l}\text { Households with Own Telephone } \\
\text { (\% of households) }\end{array}$ & 28 & 13 & 4 & 24 & 4 & 9 & 23 & 43 & 6 & 22 & .. & 13 \\
\hline $\begin{array}{l}\text { Cost of Local Phone Call } \\
\text { (US cents } / 3 \text { minutes) }\end{array}$ & 15 & 9 & 10 & 6 & 4 & 5 & 7 & 7 & 8 & 7 & 15 & 9 \\
\hline $\begin{array}{l}\text { Cost of Phone Call to the US } \\
\text { (US cents } / 3 \text { minutes) }\end{array}$ & 58 & 305 & 497 & 281 & 336 & 450 & 325 & 326 & 504 & 309 & 128 & 335 \\
\hline $\begin{array}{l}\text { Cost of Cellular Local Call } \\
\text { (US cents } / 3 \text { off-peak minutes) }\end{array}$ & 25 & 54 & 42 & 52 & 17 & 42 & 57 & 40 & 40 & 49 & 57 & 49 \\
\hline $\begin{array}{l}\text { Commercial Perception of Telephone/Fax Infrastructure } \\
\text { quality (1=worst } 7=\text { best) }\end{array}$ & 5.1 & 5.6 & 4.3 & 5.8 & 4.3 & 5.2 & 4.6 & 5.3 & 3.4 & 5.3 & 6.6 & 5.5 \\
\hline $\begin{array}{l}\text { Commercial Perception of Availability of Mobile or Cellular } \\
\text { Telephone } \quad(1=\text { worst } 7=\text { =est })\end{array}$ & 6.3 & 6.0 & 5.7 & 5.9 & 5.9 & 5.7 & 5.5 & 6.0 & 5.0 & 5.9 & 6.7 & 6.1 \\
\hline $\begin{array}{l}\text { Commercial Perception of Intemet Access in Schools } \\
\text { (1=worst } 7=\text { best) }\end{array}$ & 3.6 & 3.8 & 2.8 & 3.5 & 2.7 & 3.4 & 2.8 & 3.7 & 2.1 & 3.4 & 5.4 & 4.0 \\
\hline $\begin{array}{l}\text { Commercial Perception of Postal Efficiency } \\
\text { (1=worst } 7=\text { best) }\end{array}$ & 3.3 & 4.4 & 3.7 & 4.9 & 3.3 & 4.2 & 3.1 & 4.3 & 3.1 & 3.9 & 6.2 & 4.6 \\
\hline $\begin{array}{l}\text { Phone Faults } \\
\text { (reported faults/100 mainlines) }\end{array}$ & 48 & 18 & 57 & 23 & 97 & 39 & 24 & 34 & 64 & 25 & 11 & 37 \\
\hline $\begin{array}{l}\text { Unmet Demand } \\
(\% \text { of main telephone lines in operation) }\end{array}$ & 1 & 4 & 50 & 26 & 24 & 13 & 17 & 8 & 47 & 12 & 0 & 21 \\
\hline
\end{tabular}

Note: Data used is from the latest observation available between 1997 and 2003.

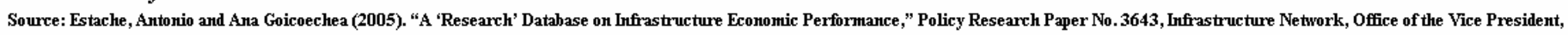
June 2005.

Figure 5: Teledensity

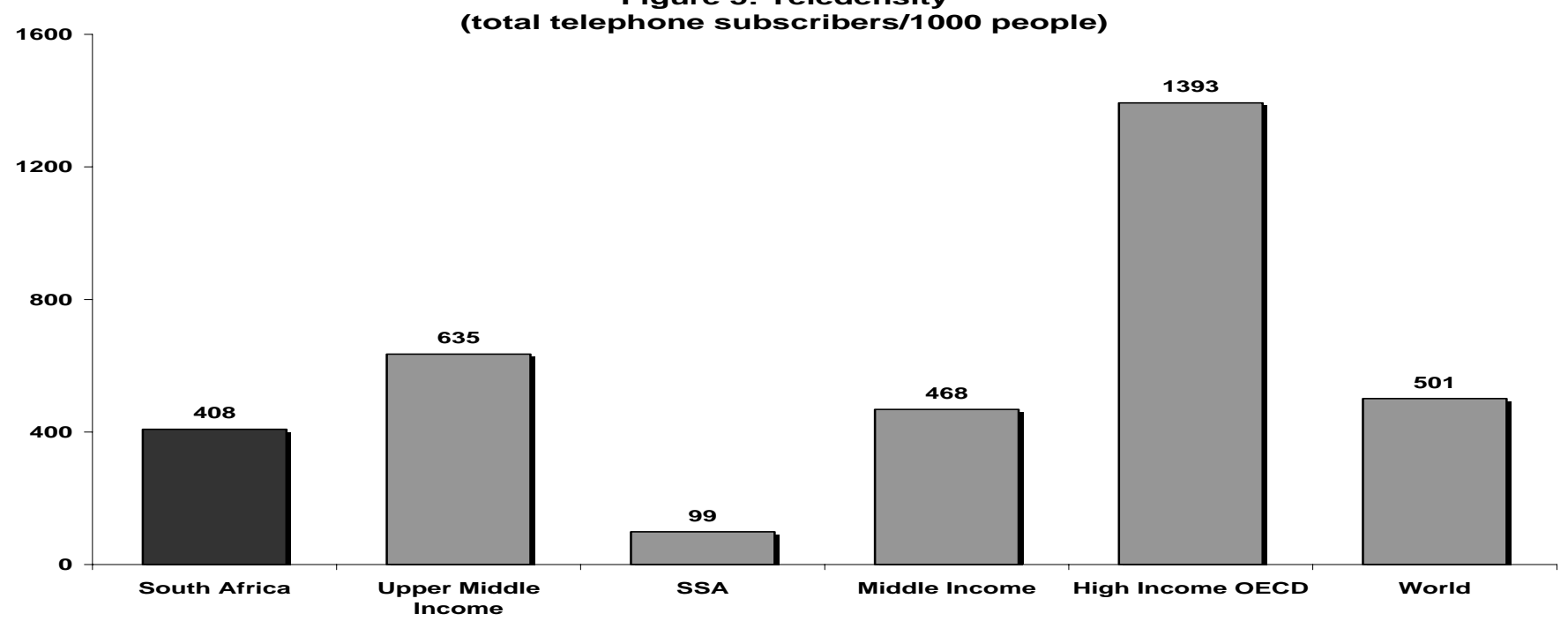


Figure 6: Phone Faults

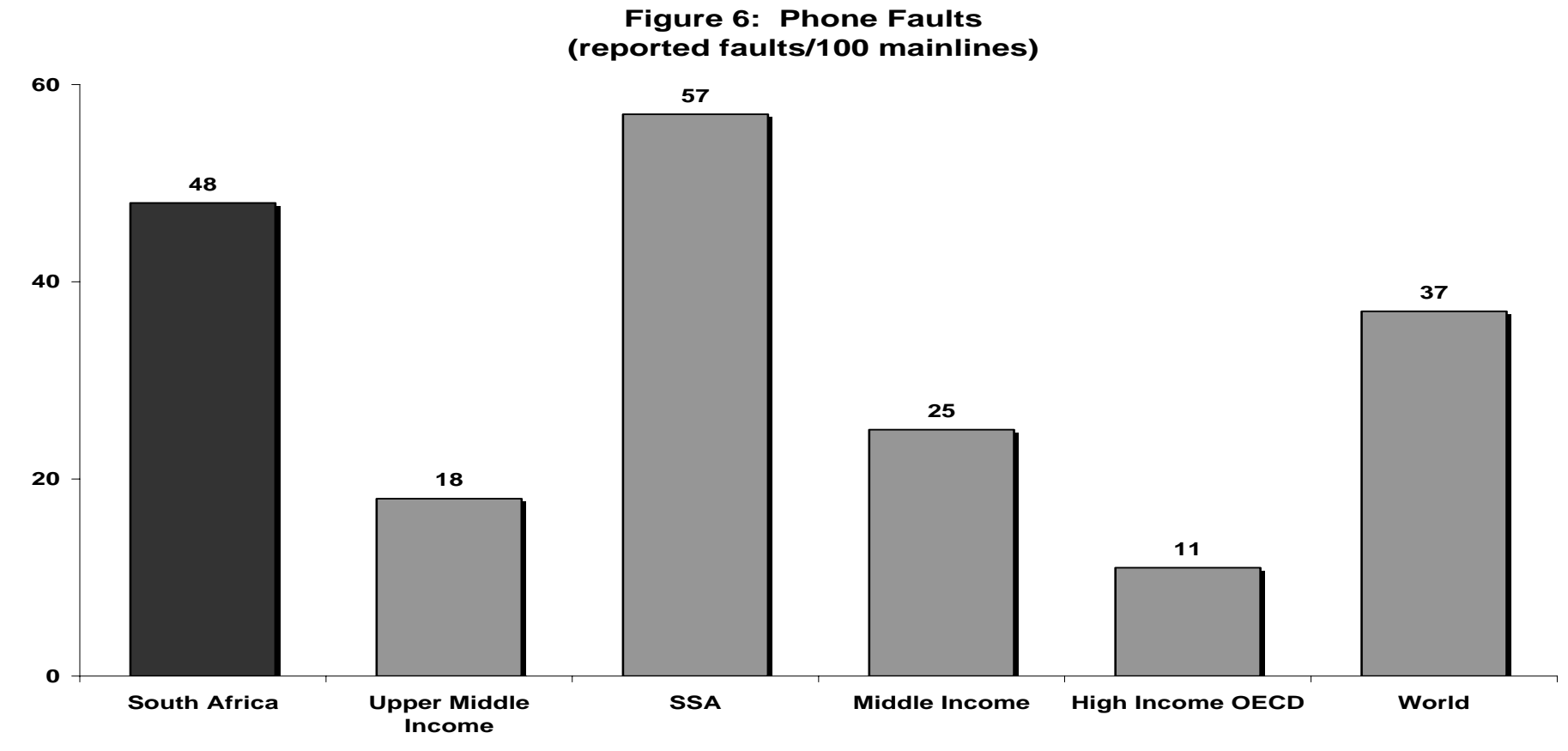

\section{Transport}

Overall assessment. The transport sector's overall performance indicators show South Africa lagging behind its comparator country groups and several other regions. This finding must be taken with caution though, reflecting at least two factors at play. First, it may simply reflect a more idiosyncratic territorial distribution of population and economic activity in a large, coastal, resource rich country such as South Africa than is the case for the average country group. Second, it may reflect some peculiarities in the type of road network that is appropriate for a country with semi-arid climate, and with a large proportion of its land surface carrying low population densities. However, it also reflects the legacy of the Apartheid era and wide inequalities in infrastructure service delivery between the privileged group and the majority of the population. Perceptions of the quality of service delivery are relatively favorable (Table 4 and Figures 7-8).

Access. Road density in terms of population (road-kilometers per 1,000 people) is twice the average for low-income countries and higher than Middle East \& North Africa, and East Asia Pacific. However, at 6.1 road-km per 1000 people it is only a third of the density of high-income OECD countries and two thirds of upper-middleincome countries. Interestingly, Brazil has significantly higher road density in terms of population (10), while Indonesia and Malaysia score lower (1.7 and 2.8). Road density in terms of land (road-kilometers per 1,000 sq km) is low (227) when compared with many other groups and is only higher than that of SSA (155) and low-income countries (181). It is much lower than in benchmark upper-middle-income countries (328). At the same time, it is important to recognize that these road density indicators for South Africa may be somewhat misleading in comparative perspective because of the specific territorial configuration of population density that is concentrated in comparatively small parts of an otherwise large national territory. To the extent that South Africa has lower than average population density and greater differences in the concentration of population and economic activity (parts of the country are very poorly inhabited with 
very little or no commercial activity) in different regions, the indicator may overstate the gap with comparator countries. For example, South Africa performance on density in terms of land appears similar to Brazil (203 road kilometers per 1,000 sq $\mathrm{km}$ ), another resource rich, coastal country with vast segments of the territory sparsely populated; similarly Indonesia and Malaysia also have very similar road density in terms of land (203 and 200 road kilometers per 1,000 sq km, respectively). ${ }^{11}$ Rail lines density in terms of population, by contrast, is very high when compared to SSA, Middle East \& North Africa, South Asia, East Asia Pacific, and Latin America \& the Caribbean. It is slightly higher than the average for all middle-income and just below the benchmark upper-middle-income group. South Africa' rail lines density in terms of land, however, is far behind those in middle-income and high-income countries and is also behind South Asia but ahead of other groups. Similar qualification for the interpretation of road densitiy applies here as well.

Quality-technical. According to the database, South Africa has one of the lowest percentages of paved roads at $21 \%$. This is lower than SSA $(25 \%)$ and low-income countries (30\%) and far behind upper-middle-income (57\%) and high-income countries $(82 \%)$. This may reflect the legacy of the strong urban bias and the economic configuration of economic activity inherited from the Apartheid era. Four important caveats are in order here. First, local information on paved roads show a higher percentage (31\%) that was already achieved in 1994 (Perkins et al. 2005); as of writing, we could not reconcile this with the number from the benchmarking database that on this indicator originates in the World Bank's World Development Report 2004. But even if the $31 \%$ figure is taken at face value, while it would imply better performance in South Africa than in SSA region, it would remain worse than in upper-middleincome countries. Second, the quality of the paved roads variable itself probably hides considerable cross-country variation: paved roads in South Africa may be of higher quality than those in most SSA countries, but this variation would presumably be much less relevant for the upper-middle-income group. Third, the proportion of roads paved may hide a relatively well developed road network in terms of road kilometers (thus inflating the denominator of the proportion), though the preceding discussion puts some limits on this possibility. Fourth, given the semi-arid climate of South Africa, and the low population densities in large parts of South Africa's geography, it is not clear what the optimal pave roads proportion might be. Nevertheless, irrespective of which proportion is used $(21 \%$ or $31 \%$ ), we note that that South Africa reports a lower proportion than its benchmark group of upper-middle-income countries, and significantly lower than high-income OECD countries.

Quality-perception. South Africa has one of the longest travel times to work in main cities (35 minutes) when compared to upper-middle-income (29 minutes), high-income OECD (32 minutes) and SSA (34 minutes) although the difference is small. The world average is 31 minutes. While the small difference makes it difficult to infer much of this comparison, the long commutes in South Africa may also reflects the inherited road network from the pre-1994 era that now results in the majority of the population often facing long and costly commutes; in some communities, commuting costs may reach prohibitive levels as proportion of the prospective wage, thereby discouraging job

${ }^{11}$ Euchache and Goicoechea (2005), Table A4-2, pp. 105-07. 
search and earning opportunities for the poor. ${ }^{12}$ Commercial perception of service delivered by the roads department is one of the highest in the world at 5.3, only bettered by MENA at 5.5. The average for high-income OECD countries is 4.3. Commercial perception of ports facilities and railroad services are lower than for roads but are still much higher than low and middle-income countries and are not too far behind the ratings of high-income OECD countries. Commercial perception of air transport services gets the highest ranking of all transport sectors at 5.6, which compares well with 5.7 for high-income OECD countries.

Table 4: Benchmarking of South Africa's Performance in the Transport Sector

\begin{tabular}{|c|c|c|c|c|c|c|c|c|c|c|c|c|}
\hline Transport & $\begin{array}{l}\text { South } \\
\text { Afica }\end{array}$ & $\begin{array}{l}\text { Upper } \\
\text { Middle } \\
\text { Income }\end{array}$ & SSA & $\begin{array}{c}\text { Middle } \\
\text { East } \\
\text { and } \\
\text { Noth } \\
\text { Afica } \\
\end{array}$ & $\begin{array}{l}\text { South } \\
\text { Asia }\end{array}$ & $\begin{array}{c}\text { East } \\
\text { Asia } \\
\text { Pacific }\end{array}$ & $\begin{array}{c}\text { Latin } \\
\text { America } \\
\& \\
\text { Canibbean }\end{array}$ & $\begin{array}{c}\text { Europe } \\
\& \\
\text { Central } \\
\text { Asia }\end{array}$ & $\begin{array}{l}\text { Low } \\
\text { Income }\end{array}$ & $\begin{array}{l}\text { Middle } \\
\text { Income }\end{array}$ & $\begin{array}{l}\text { High } \\
\text { Income } \\
\text { OECD }\end{array}$ & World \\
\hline $\begin{array}{l}\text { Road Density in Terms of Population } \\
\text { (road-km/1000 people) }\end{array}$ & 6.1 & 9.2 & 3.3 & 4.8 & 2.4 & 4.2 & 5.7 & 8.6 & 3.0 & 7.0 & 17.3 & 6.7 \\
\hline $\begin{array}{l}\text { Road Density in Terms of Land } \\
\text { (road-km/1000 sq km) }\end{array}$ & 227 & 1076 & 156 & 609 & 545 & 276 & 713 & 580 & 181 & 702 & 1340 & 841 \\
\hline $\begin{array}{l}\text { Rail Lines Density in Terms of Population } \\
\text { (rail-km/1000 people) }\end{array}$ & 0.44 & 0.51 & 0.18 & 0.1 & 0.05 & 0.14 & 0.33 & 0.47 & 0.13 & 0.4 & 0.53 & 0.33 \\
\hline $\begin{array}{l}\text { Rail Lines Density in Terms of Land } \\
\text { (rail-km/1000 sq km) }\end{array}$ & 16.5 & 31.3 & 3.7 & 5.5 & 18.8 & 8.9 & 14.8 & 33.2 & 9.3 & 23.3 & 46.2 & 23.1 \\
\hline $\begin{array}{l}\text { Travel Time to Work in Main Cities } \\
\text { (minutes/one-way work trip) }\end{array}$ & 35 & 29 & 34 & 25 & 27 & 36 & 29 & 29 & 33 & 29 & 32 & 31 \\
\hline $\begin{array}{l}\text { Commercial Perception of Services Delivered by Road } \\
\text { Department Public Works (1=worst } 7=\text { best) }\end{array}$ & 5.3 & 4.1 & 3.7 & 5.5 & 3.9 & 4.4 & 4.0 & 3.6 & 3.4 & 4.1 & 4.3 & 4.0 \\
\hline $\begin{array}{l}\text { Commercial Perception of Port Facilities } \\
\text { (1=worst } 7=\text { best })\end{array}$ & 4.7 & 3.8 & 3.8 & 4.1 & 3.4 & 3.6 & 3.1 & 3.6 & 2.6 & 3.6 & 5.4 & 4.2 \\
\hline $\begin{array}{l}\text { Commercial Perception of Railroad Services } \\
\text { (1=worst 7=best) }\end{array}$ & 4.3 & 2.9 & 3.2 & 3.5 & 3.6 & 3.1 & 1.5 & 3.7 & 2.7 & 2.7 & 4.8 & 3.4 \\
\hline $\begin{array}{l}\text { Commercial Perception of Air Transport Services } \\
(1=\text { worst } 7=\text { best })\end{array}$ & 5.6 & 4.5 & 4.5 & 4.9 & 4.2 & 4.4 & 4.2 & 3.9 & 3.6 & 4.4 & 5.7 & 4.8 \\
\hline $\begin{array}{l}\text { Paved Roads } \\
\text { (\% of total roads) }\end{array}$ & 21 & 57 & 25 & 56 & 38 & 32 & 36 & 76 & 30 & 52 & 82 & 50 \\
\hline
\end{tabular}

Note: Data used is from the latest observation available between 1997 and 2003 .

Source: Estache, Antonio and Ana Goicoechea (2005). "A 'Research' Datahase on Infrastructure Economic Performance," Policy Research Paper No. 3643, Infrastructure Network, 0ffice of the Vice President, June 2005.

${ }^{12}$ Department of Transport (1999) estimated that based on OHS data for 1995, the average public transport trip in South Africa was $20 \mathrm{~km}$, about twice the length experienced in Asian developing countries. South African commuters spent about $40 \%$ more time traveling than their Asian counterparts. 
Figure 7: Road Density in Terms of Population

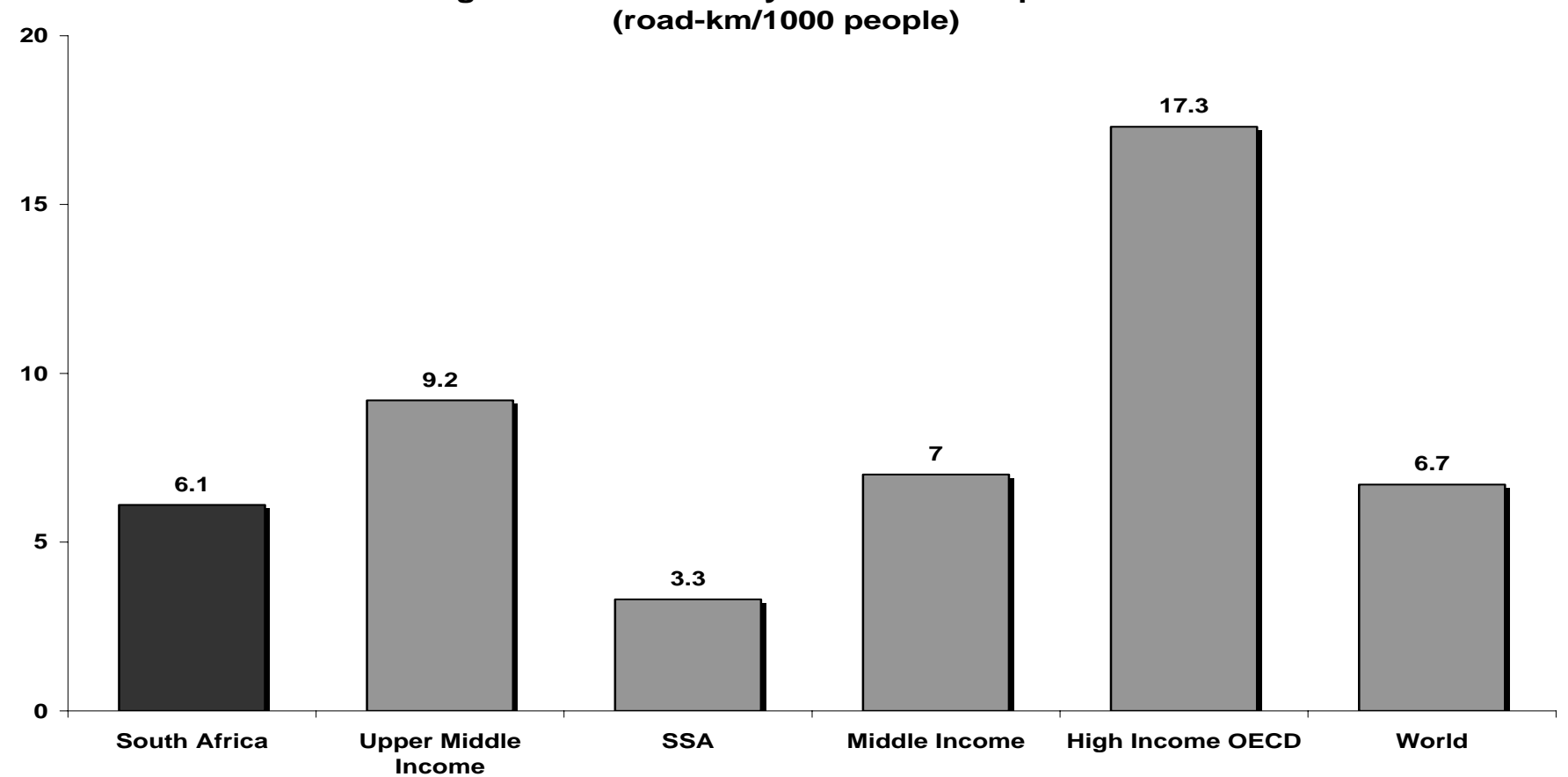

(road-km/1000 people)

Figure 8: Paved Roads

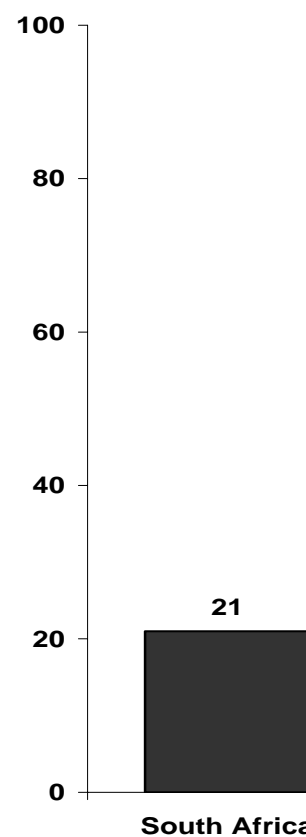
(\% of total roads)

82
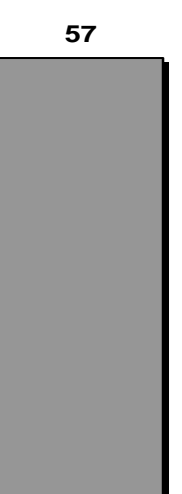

Upper Middle Income

\section{Large differences from the benchmark}

As a conclusion to the detailed benchmarking of South Africa's infrastructure performance discussed above, it might be useful to highlight some of the large differences-positive and negative - against the areas where performance differences are small between South Africa and comparator groups of countries, especially the benchmark upper-middle-income group. With 
appropriate caveats, this selection of indicators showing particularly "large deviations" (which we define as plus or minus $10 \%$ from the benchmark) from the benchmark can be taken as indicative of the possible significant strengths and weaknesses in infrastructure performance. We also note the areas where performance has been broadly on par (within the $+/ 10 \%$ deviation from the benchmark) with that in upper middle income countries. Together with the additional, country specific indicators and analysis of sectors, it is hoped that this could help focus the attention of policymakers on those areas where performance improvements are most needed (Table 5).

In electricity, comparative indicators suggest that access remains a major issue, despite important gains in expanding access in recent years, while technical efficiency for the served population is relatively high. Indicators of internal technical efficiency (e.g., losses in distribution/transmission) and low prices are favorable compared with the benchmark country group as well as other comparators. These are comparatively strong dimensions of South Africa's performance in electricity. Also, the energy intensity, measured by the energy use per PPP GDP, appears broadly on par with that of the benchmark upper-middle-income countries. However, indicators of access to network and reported access to service by households fall significantly short of what would be expected of a well-run sector in an upper-middle-income country. While much was done in recent years to extend the service to the previously unserved population, much more remains to be done, especially in rural (and peri-urban) areas.

In water and sanitation, access is much lower than in benchmark upper-middle-income countries, especially in rural areas. Quality indicators also indicate relative shortfalls. To the extent that the shortfalls reflect the internal imbalances between supply and demand for this vital service that is closely monitored internationally under the Millennium Development Goals (MDGs) because of its multiple links with health and the general wellbeing, expanding access and quality in this sector may be particularly important.

In information and communications technology, pricing of services catering the wealthier segments of the population and the large, internationally oriented enterprise sector-cellular calls and some international calls (to the U.S., for example) - reflect generally good and competitively provided services. We note, however, that in the current debate, broadband speed and access in particular remain a strong area of concern. Arguably, broadband services are of particular concern to economic activity. ${ }^{13}$ Further, local service rates, which may be used relatively heavily by the middle class and the poorer segments of the population, are among the highest in the world. Finally, access rates, especially in poor, rural areas are much lower compared with the benchmark. The implication is that more could be done to raise competitiveness in the local service segment and generally expand access to the rural areas.

Finally, in transport, both road and rail, all basic indicators of performance show worse performance than the benchmark upper middle-income countries, even when accounting for some uncertainty about specific indicators and the caveats of interpretation. While this in part may reflect the peculiar territorial distribution of economic activity, population, markets, and transportable goods, it also reflects the legacy of Apartheid. While more in-depth comparison of a more detailed battery of road indicators of quality and quantity of service would be needed to draw firm conclusions, the indicators presented do suggest the need for a deeper look at the

${ }^{13}$ See Truen and Hodge (2005) and Reynolds (2005). 
adequacy of the road and rail network to service the needs of a growing, upper-middle-income countries, including large segments of the rural population.

Table 5: South Africa's Infrastructure Performance - Significant Deviations from Benchmark

\begin{tabular}{|c|c|c|c|c|c|}
\hline & $\begin{array}{l}\text { South } \\
\text { Africa }\end{array}$ & $\begin{array}{c}\text { Benchmark } \\
\text { Upper } \\
\text { Middle } \\
\text { Income } \\
\end{array}$ & SSA & World & \begin{tabular}{|c} 
South Africa's \\
performance vs \\
Benchmark \\
\end{tabular} \\
\hline \multicolumn{6}{|l|}{ Deviation of $+10 \%$ or more from Benchmark } \\
\hline $\begin{array}{l}\text { Electricity: Average End-User Prices (US cents/kWh) - } \\
\text { (Residential/Non-Energy: Residential) }\end{array}$ & $3 / 2$ & $9 / 7$ & $6 / 5$ & $9 / 6$ & Outperform \\
\hline $\begin{array}{l}\text { Energy: Electric Power Transmission and Distribution Losses } \\
(\% \text { of total output) }\end{array}$ & 8.0 & 14.0 & 19.0 & 14.0 & Outperform \\
\hline $\begin{array}{l}\text { ICT: Cost of Phone Call to the US } \\
\text { (US cents } / 3 \text { minutes) }\end{array}$ & 58 & 305 & 497 & 335 & Outperform \\
\hline $\begin{array}{l}\text { ICT: Cost of Cellular Local Call } \\
\text { (US cents } / 3 \text { off-peak minutes) }\end{array}$ & 25 & 54 & 42 & 49 & Outperform \\
\hline \multicolumn{6}{|l|}{ Deviation of between $-10 \%$ and $+10 \%$ from Benchmark } \\
\hline $\begin{array}{l}\text { Enerty: Energy Use Per PPP GDP } \\
\text { (kg of oil equivalent/1000 PPP dollars, Constant 2000) }\end{array}$ & 257 & 249 & 364 & 275 & Average \\
\hline $\begin{array}{l}\text { Water: Access to Improved Water Sources } \\
(\% \text { of population) }\end{array}$ & 87 & 93 & 64 & 80 & Average \\
\hline $\begin{array}{l}\text { Water: Households Using Piped or Well Water as Main Source of } \\
\text { Drinking Water } \quad(\% \text { of households) }\end{array}$ & 85 & 80 & 78 & 79 & Average \\
\hline $\begin{array}{l}\text { ICT: Cellular Teledensity } \\
\text { (cellular subscribers/1000 people) }\end{array}$ & 364 & 381 & 73 & 296 & Average \\
\hline \multicolumn{6}{|l|}{ Deviation of $-10 \%$ or more from Benchmark } \\
\hline $\begin{array}{l}\text { Energy: Access to Electricity Network } \\
(\% \text { of Population) }\end{array}$ & 66 & 87 & 15 & 60 & Underperform \\
\hline $\begin{array}{l}\text { Energy: Households Reporting Access to Electricity } \\
\text { (\% of households) }\end{array}$ & 65 & 74 & 23 & 45 & Underperform \\
\hline $\begin{array}{l}\text { Water: Access to Improved Sanitation } \\
(\% \text { of population) }\end{array}$ & 67 & 86 & 37 & 64 & Underperform \\
\hline $\begin{array}{l}\text { ICT: Mainlines Teledensity } \\
\text { (mainlines subscribers/1000 people) }\end{array}$ & 107 & 261 & 31 & 213 & Underperform \\
\hline $\begin{array}{l}\text { ICT: Cost of Local Phone Call } \\
\text { (US cents } / 3 \text { minutes) }\end{array}$ & 15 & 9 & 10 & 9 & Underperform \\
\hline $\begin{array}{l}\text { ICT: Phone Faults } \\
\text { (reported faults/100 mainlines) }\end{array}$ & 48 & 18 & 57 & 37 & Underperform \\
\hline $\begin{array}{l}\text { Transport: Road Density in Terms of Population } \\
\text { (road-km/1000 people) }\end{array}$ & 6.1 & 9.2 & 3.3 & 6.7 & Underperform \\
\hline $\begin{array}{l}\text { Transport: Road Density in Terms of Land } \\
(\text { road-km/1000 sq km) }\end{array}$ & 227 & 1076 & 156 & 841 & Underperform \\
\hline $\begin{array}{l}\text { Transport: Rail Lines Density in Terms of Land } \\
\text { (rail-km/1000 sq km) }\end{array}$ & 17 & 31 & 4 & 23 & Underperform \\
\hline $\begin{array}{l}\text { Transport: Travel Time to Work in Main Cities } \\
\text { (minutes/one-way work trip) }\end{array}$ & 35 & 29 & 34 & 31 & Underperform \\
\hline $\begin{array}{l}\text { Transport: Paved Roads } \\
(\% \text { of total roads })\end{array}$ & 21 & 57 & 25 & 50 & Underperform \\
\hline
\end{tabular}

Note: Data used is from the latest observation available between 1997 and 2003.

Source: Estache, Antonio and Ana Goicoechea (2005). "A 'Research' Database on Infrastructure Economic Performance," Policy Research Paper No. 3643, Infrastructure Network, Office of the Vice President, June 2005. 


\section{The rural-urban divide}

Finally, given the clear "urban bias" of infrastructure distribution in many developing countries, including South Africa, no discussion of South Africa's infrastructure performance can be complete without at least a preliminary look at the rural-urban divide. However, internationally comparative data on urban and rural dimensions or infrastructure performance are limited. In the data base used, for example, there are no rural and urban data for transport directly available, and indicators for other sectors are generally more limited. Nevertheless, some available indicators do provide a glimpse of the important differences in infrastructure performance between rural and urban areas of South Africa (Table 6).

\section{Table 6: Benchmarking Infrastructure Performance in Rural and Urban Areas in South Africa}

\begin{tabular}{|c|c|c|c|c|c|c|}
\hline & \multicolumn{2}{|c|}{ South Africa } & \multicolumn{2}{|c|}{$\begin{array}{l}\text { Upper Middle } \\
\text { Income }\end{array}$} & \multicolumn{2}{|c|}{ SSA } \\
\hline & Rural & Urban & Rural & Urban & Rural & Urban \\
\hline $\begin{array}{l}\text { Households Reporting Access to Electricity } \\
\text { (\% of households) }\end{array}$ & 37 & 84 & 30 & 90 & 8 & 54 \\
\hline $\begin{array}{l}\text { Access to Improved Water Sources } \\
\text { (\% of population) }\end{array}$ & 73 & 98 & 85 & 96 & 54 & 83 \\
\hline $\begin{array}{l}\text { Access to Improved Sanitation } \\
\text { (\% of population) }\end{array}$ & 44 & 86 & 76 & 91 & 28 & 54 \\
\hline $\begin{array}{l}\text { Households with Own Telephone } \\
\text { (\% of households) }\end{array}$ & 6 & 43 & 1 & 17 & 1 & 10 \\
\hline
\end{tabular}

Note: Data used is from the latest observation available between 1997 and 2003.

Source: Estache, Antonio and Ana Goicoechea (2005). “A 'Research' Database on Infrastructure Economic Performance," Policy Research Paper No. 3643, Infrastructure Network, Office of the Vice President, June 2005.

In a nutshell, the available indicators on electricity, water and sanitation, and telephone services suggest that while urban areas score relatively well, there is a significant shortfall in access to improved water and sanitation in rural areas of South Africa compared with the benchmark upper-middle-income countries. Therefore, territorial equity between rural and urban areas for some infrastructure services that may matter most for the poor-water and sanitation - is a major issue. In electricity, access in urban areas is lower than in upper middleincome countries, while in rural areas access is above the benchmark. This reflects major efforts (and gains) in recent years to expand access in South Africa; nevertheless, the overall access, as noted in the earlier sections of the paper, remains below the benchmark. In access to improved water and sanitation, however, rural areas of South Africa lag significantly behind their upper middle-income country counterparts. Finally, telephone ownership is South Africa appears to be better in both rural and rural areas than in the upper-middle-income countries. This should not be taken automatically to imply better service, for which comparative indicators in rural areas are not available. In fact, as noted in the earlier sections, other aggregate indicators of telecom service performance (especially in local services) suggest considerable scope for improvement. 


\section{Conclusion}

In sum, we have benchmarked South Africa's infrastructure performance on all four major infrastructure sectors in terms of key indicators of access, affordability-pricing, and quality using the new World Bank database of infrastructure sector outcome indicators from 207 countries. The broad results suggest the following: access remains a major issue in electricity and, especially, water and sanitation (particularly in rural areas), and so does performance in local telecom services. Even transport performance appears comparatively less strong than would be expected, though more in-depth analysis of comparative performance of transport may be warranted to develop a more nuanced picture, especially across different modes of transport.

More specifically, compared to the benchmark and other country groupings, South Africa's utilities provide solid service at reasonable quality and, in some cases, very competitive prices. But there remain significant shortfalls relative to benchmarks in all infrastructure sectors, largely related to limited access and less than expected quality, especially in rural areas, where large numbers of South Africa's poor live with limited or no access to service. To catch up with its income group in terms of these indicators, South Africa will need to improve access to and quality of electricity, and water and sanitation services in presently unserved areas. Indicators of transport performance, while less definitive, potentially also point in the same direction. Even in telecom, the most globalized and "modern" infrastructure sector, access in rural areas can be improved and pricing of local services remains uncompetitive. Moreover, to put it simply, if South Africa is to strengthen its overall infrastructure performance, it will need to improve these dimensions' performance in the sectors faster than the average country in the upper-middle-income group while maintaining or improving its position in the already strong areas of performance. This will not be easy in competition within a group of countries all aspiring to move to much higher levels of income and with ambitious poverty reduction targets. But catching up with these relative shortfalls may also help South Africa reduce its economic inequities and poverty rates and, therefore, meet the infrastructure related Millennium Development Goals (MDGs). It could also help address some of the concerns about South Africa's external and industrial competitiveness and service delivery that in good part depends on the efficiency and capacity of network utilities to deliver basic services to population and businesses alike. 


\section{BotSWANA}

Indicators on Botswana allow a detailed comparative benchmarking of the similar sort carried out for the initial exercise for South Africa. Available indicators for Botswana are as follows: four for electricity, three for water and sanitation, twelve for ICT, and seven for transport. Nevertheless, the reader should keep in mind general caveats with respect to interpretation of comparisons mentioned above in the SACU-wide summary of findings, and below in specific sector assessments for this country.

\section{Energy - electricity}

Access: Botswana's access to electricity network is one of the lowest in the world with only $10 \%$ of the population having access (Table 1, Figure 1). When compared with $87 \%$ access for upper-middle-income (Botswana's income group), Botswana's performance is extremely poor. Not only is Botswana lagging far behind comparator country groups, it actually performs poorly in comparison to low-income countries, with $31 \%$ of the population having access to electricity and $15 \%$ for its geographical comparison group of Sub-Saharan Africa (SSA). It is true that this in part reflects peculiar pattern of spatial distribution of population and economic activity, as well as the fact that Botswana has few local means of generating electricity and, therefore, must rely heavily on imports, mainly from South Africa. But the overall access is still indicative of the very large inequities in this basic service in Botswana.

\section{Table 1: Benchmarking Botswana’s Electricity Sector Performance}

\begin{tabular}{|c|c|c|c|c|c|c|c|c|c|c|c|c|}
\hline Energy & Botswana & $\begin{array}{c}\text { Main } \\
\text { Benchumark } \\
\text { Upper } \\
\text { Middle } \\
\text { Income }\end{array}$ & SSA & $\begin{array}{l}\text { Middle } \\
\text { East and } \\
\text { Noth } \\
\text { Africa }\end{array}$ & $\begin{array}{l}\text { South } \\
\text { Asia }\end{array}$ & $\begin{array}{r}\text { East } \\
\text { Asia } \\
\text { Pacific }\end{array}$ & $\begin{array}{c}\text { Latin } \\
\text { America } \\
\& \\
\text { Caribhean }\end{array}$ & $\begin{array}{c}\text { Europe \& } \\
\text { Centryl } \\
\text { Asia }\end{array}$ & $\begin{array}{l}\text { Low } \\
\text { Income }\end{array}$ & $\begin{array}{l}\text { Middle } \\
\text { Income }\end{array}$ & $\begin{array}{l}\text { High } \\
\text { Income } \\
\text { OECD }\end{array}$ & World \\
\hline Access to Electricity Network (\% of Population) & 10 & 87 & 15 & 88 & 31 & 54 & 79 & 99 & 31 & 85 & .. & 60 \\
\hline $\begin{array}{l}\text { Electricity Average End-User Prices (US cents/KWh) - } \\
\text { (Residential/Non-Residential) }\end{array}$ & $4 / 3$ & $9 / 7$ & $6 / 5$ & & & $5 / 5$ & $10 / 8$ & $6 / 6$ & $6 / 6$ & $8 / 7$ & $13 / 6$ & $9 / 6$ \\
\hline Commercial Perception of Electricity service (1=worst $7=$ best) & 4.8 & 5.2 & 4.3 & 5.1 & 2.6 & 4.3 & 4.2 & 4.8 & 2.8 & 4.7 & 6.3 & 5.0 \\
\hline $\begin{array}{l}\text { Commercial Perception of Public Agency Electricity Provider } \\
(1=\text { worst 7=best) }\end{array}$ & 5.7 & 5.3 & 4.3 & 6.0 & 3.8 & 5.0 & 4.8 & 4.8 & 4.0 & 5.2 & 5.3 & 4.8 \\
\hline
\end{tabular}

Note: Data used is from the latest observation available between 1997 and 2003.

Source: A "Research" Datahase of Infrastructure Economic Perforntance, Antonio Estache and Ana Goicoechea, World Bank Infrastructure Network, 0ffice of the Vice President, June 2005.

Affordability - pricing: The average end-user prices (US cents/Kwh) in Botswana are one of the cheapest in the world at 4 cents for residential and 3 cents for non-residential customers. These prices are significantly cheaper than prices in upper-middle-income countries which average around 9 cents and 7 cents, respectively. Prices are more comparable to SSA at 6 and 5 cents. In contrast the highest income group we looked at, OECD, has the most expensive rates at 13 and 6 cents. This is in large part a reflection of the competitive price of electricity, which is largely imported from South Africa. 
Quality - perceptions: In terms of commercial perception of electricity service, Botswana ranks favorably with its comparable income group. Botswana rates 4.8 ( $7=$ best and 1=worst) compared to 5.2 for upper-middle-income group. Comparison to SSA (4.3) shows that commercial perception of electricity service is better in Botswana but falls short of world average of 5.0. With regards to commercial perception of public agency electricity provider, Botswana is has one of the highest rankings at 5.7, which is higher than upper-middle-income (5.3) and even beats OECD (5.3) and is only bettered by Middle East and North Africa (MENA) group at 6.0. Given that Botswana has one of the lowest access to electricity network, the favorable perception results may reflect a selection bias as only customers with access to service are most likely to respond those these kind of surveys.

\section{Water and sanitation}

Access: Botswana has one of the highest access rates to improved water sources with $95 \%$ of the total population having access (Table 2, Figure 1). This is slightly higher than $93 \%$ access for upper middle-income countries and far ahead of SSA rate of 64\%. Only the OECD grouping has higher access at $99 \%$. And when one looks at the urban/rural mix, the outcome is very encouraging with rural access of $90 \%$, which once again is much better than the rural access for all other comparable groups with the exception of OECD. Urban access is at 100\%, same level as OECD.

The picture is very different when we turn to access to improved sanitation. Only 41 percent of the population has access to improved sanitation, which is less than half the access level for upper-middle-income countries at $86 \%$ and also far behind most of the other groups and is same level as low-income group and only slightly higher than $37 \%$ of SSA. The world average for access to improved sanitation is $64 \%$ of population. The picture is even bleaker when one looks at the urban/rural mix, with rural access a mere $25 \%$, which is even lower than SSA rural access of $28 \%$ and far behind $76 \%$ for upper-middle-income countries. Urban access is more than twice the rate for rural access at $57 \%$ but is significantly lower than all other regions and income groups and is in line with SSA average (54\%).

Table 2: Benchmarking Botswana's Water and Sanitation Sector Performance

\begin{tabular}{|c|c|c|c|c|c|c|c|c|c|c|c|c|}
\hline Water' & Botswana & $\begin{array}{l}\text { Main } \\
\text { Benchunark } \\
\text { Ipper } \\
\text { Middle } \\
\text { Incoume } \\
\end{array}$ & SSA & $\begin{array}{c}\text { Middle } \\
\text { East and } \\
\text { Noth } \\
\text { Africa }\end{array}$ & $\begin{array}{l}\text { South h } \\
\text { Asia }\end{array}$ & $\begin{array}{l}\text { East } \\
\text { Asia } \\
\text { Pacific }\end{array}$ & $\begin{array}{l}\text { Latin } \\
\text { America } \\
\& \\
\text { Carihhean }\end{array}$ & $\begin{array}{l}\text { Eurppe \& } \\
\text { Centul } \\
\text { Asia }\end{array}$ & $\begin{array}{l}\text { Low } \\
\text { Income }\end{array}$ & $\begin{array}{l}\text { Middle } \\
\text { Income }\end{array}$ & $\begin{array}{l}\text { High } \\
\text { Income } \\
\text { OECD }\end{array}$ & \\
\hline Access to Improved WW teter Sources (\% of populdation) & 95 & 93 & 64 & 85 & 72 & 75 & 90 & 87 & 65 & 89 & 99 & 80 \\
\hline Access to Improvered Sernitation (\% of poppulation) & 41 & 86 & 37 & 77 & 48 & 60 & 77 & 78 & 41 & 79 & 100 & 64 \\
\hline Commercial Perception of Water Service (1=worst?=best) & 5.7 & 50 & 4.2 & 5.6 & 4.1 & 4.8 & 4.7 & 4.6 & 4.0 & 49 & 5.2 & 4.7 \\
\hline
\end{tabular}

Note: Data used isfrom the latest observation available between 1997 and 2003.

Source: A "Research" Datahase of Infrastructure Economic Performance, Antonio Estache and Ana Goicoechea, World Bank Infrastructure Network, Office of the Vice President, June 2005. 
Quality - perceptions: Commercial perception of water service is one of the highest ratings of all groups at 5.7 out of 7, while the rating for upper-middle-income is 5 and SSA is 4.2. Botswana also has higher rating than OECD at 5.2. Given the level of access level, the high ranking is not a surprising but the fact that it is higher than OECD may reflect a slight "urban bias" of the perception indicator. 


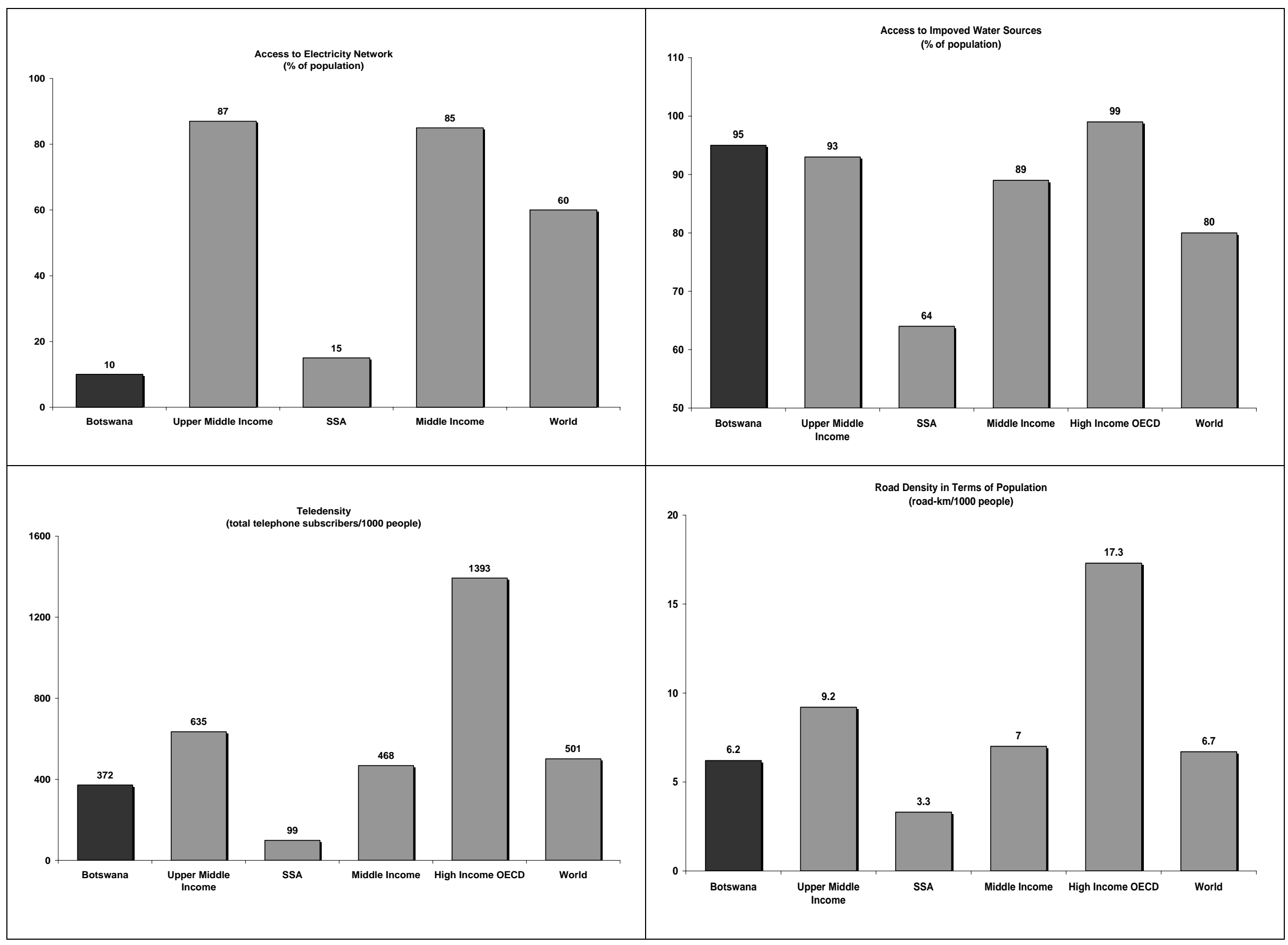




\section{Information and Communications Technology (ICT)}

Access: In terms of mainline teledensity, Botswana compares poorly to its comparable income group but is much better than some other income groups and regional comparisons (Table 3). Botswana's mainline teledensity is 75 (subscribers per 1000 people) compared to 261 for upper middle-income countries, 572 for OECD and a world average of 213. However Botswana's mainline teledencity is twice as much as SSA, South Asia and low-income group and is the same as East Asia Pacific region. The trend is similar when we look at cellular teledencity, with Botswana underperforming upper-middle-income but to a lesser degree and doing much better than SSA, South Asia, low-income as well as East Asia Pacific. Botswana also has higher penetration when compared to the broader middle-income group.

Affordability - pricing: The cost of a 3-minute local call in US cents is one of the cheapest at 2 cents, which is $1 / 4$ of the cost of similar call in upper-middle-income countries and $1 / 5$ of SSA cost. The high-income OECD countries have the most expensive rate at 15 cents and the average for the world is 9 cents. On the other hand, a 3-minute phone call to the US is about $20 \%$ more expensive (\$3.64) than upper-middle-income countries and almost three times more expensive than OECD countries. The cost of international call to the US is the most expensive when dialed from low-income group of countries at just over $\$ 5$ for a 3-minute call followed closely by SSA at \$4.97. With the exception of South Asia region, Botswana has one of the cheapest cellular local call rates at 33 US cents per 3 off-peak minutes. The upper-middle-income group of countries charge 63\% more and high-income OECD 73\% more. The rate for SSA is 42 cents with average world rate at just under 50 cents.

Table 3: Benchmarking Botswana's Performance in the ICT Sector

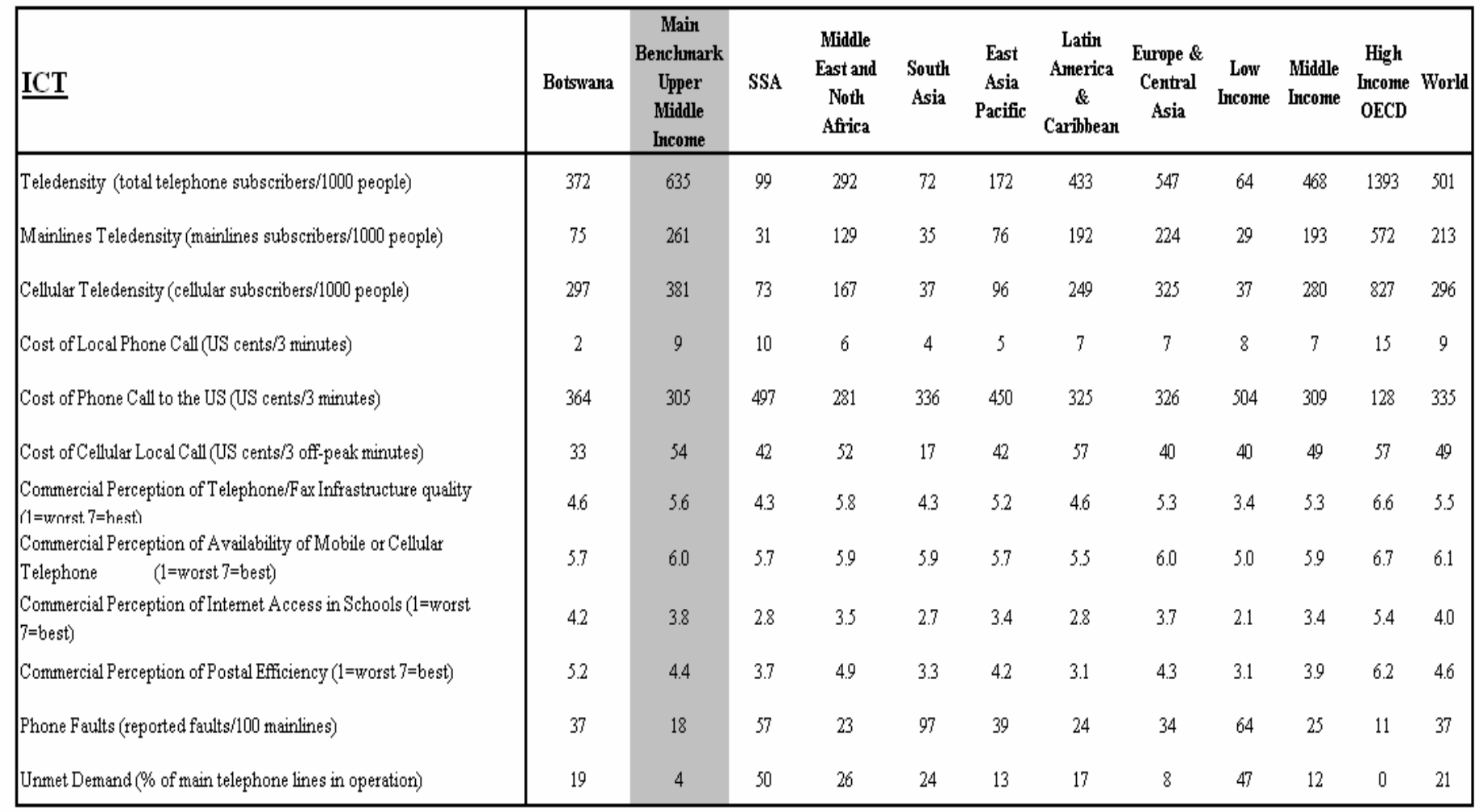

Note: Data used is from the latest observation available between 1997 and 2003.

Source: A "Research" Database of Infrastructure Economic Performance, Antonio Estache and Ana Goicoechea, World Bank Infrastructure Network, 0ffice of the Vice President, June 2005. 
Quality - technical: Reported faults per 100 telephone mainlines is high by upper-middleincome country standards at 37 compared to 18 but are significantly better than SSA (57) and low income (64). Botswana's performance is in line with world average while the high-income OECD countries are far ahead at 11.

Quality - perceptions: Commercial perception of telephone infrastructure rates at 4.6 compared to 5.6 for upper-middle-income countries and 6.6 for high-income OECD countries. This is slightly above SSA and South Asia but lags most other regions and income groups with the exception of low-income. Not surprisingly commercial perception of mobile phone availability ranks significantly higher than telephone infrastructure for Botswana as well as all other regions and income groups. Nonetheless, Botswana still lags its income group and has similar rating as SSA. However, perceptions of internet access in schools and postal efficiency are higher than all other regions and income groups with the exception of OECD.

\section{Transport}

Access: Road density in terms of population (road-kilometers per 1,000 people) is only twothirds of that for upper-middle-income countries and a third of high-income OECD but is twice as much as SSA and significantly higher than MENA, South Asia and East Asia Pacific (Table 4). The situation of road density in terms land (road-kilometers per $1000 \mathrm{sq} \mathrm{km}$ ) is significantly worse with only $18 \mathrm{~km}$ of road - there are only five countries with worse road density: Mali, Mauritius, Niger, Sudan and UAE. The comparable figure for upper-middle-income countries is $1,076 \mathrm{~km}$, and 1,340 for OECD, while SSA has road density of $156 \mathrm{~km}$. However, this could be a reflection of population density given the large size of the country and small population concentrated along the South African border.

Table 4: Benchmarking Botswana's Performance in the Transport Sector

\begin{tabular}{|c|c|c|c|c|c|c|c|c|c|c|c|c|}
\hline Transpolt & Botswanta & $\begin{array}{c}\text { Main } \\
\text { Benchumark } \\
\text { Ipper } \\
\text { Middle } \\
\text { Incomte } \\
\end{array}$ & SSA & $\begin{array}{l}\text { Middle } \\
\text { East and } \\
\text { Noth } \\
\text { Africa }\end{array}$ & $\begin{array}{l}\text { South } \\
\text { Asia }\end{array}$ & $\begin{array}{c}\text { East } \\
\text { Asia } \\
\text { Pacific }\end{array}$ & $\begin{array}{c}\text { Latin } \\
\text { America } \\
\& \\
\text { Carihhean }\end{array}$ & $\begin{array}{c}\text { Europe \& } \\
\text { Central } \\
\text { Asia }\end{array}$ & $\begin{array}{l}\text { Low } \\
\text { Income }\end{array}$ & $\begin{array}{l}\text { Middle } \\
\text { Income }\end{array}$ & $\begin{array}{l}\text { High } \\
\text { Income } \\
\text { OECD }\end{array}$ & World \\
\hline Road Density in Terms of Population(road-km/1000 people) & 6.2 & 9.2 & 33 & 4.8 & 2.4 & 4.2 & 5.7 & 8.6 & 30 & 7.0 & 173 & 6.7 \\
\hline Road Density in Terms of Land (road-km/1000 sq km) & 18 & 1076.4 & 155.7 & 608.9 & 544.6 & 276.4 & 712.7 & 580.3 & 181 & 702 & 1340.4 & 840.6 \\
\hline $\begin{array}{l}\text { Conmercial Perception of Services Delivered by Road } \\
\text { DepartmentitPublic Wooks (1=worst ?=best) }\end{array}$ & 53 & 4.1 & 3.7 & 5.5 & 3.9 & 4.4 & 4.0 & 3.6 & 3.4 & 4.1 & 4.3 & 4.0 \\
\hline Commercial Perception of Port Faciities (1=worst ?=best) & 2.9 & 3.8 & 3.8 & 4.1 & 3.4 & 36 & 3.1 & 3.6 & 2.6 & 3.6 & 5.4 & 4.2 \\
\hline Conmercial Perception of Railroad Services (1=worst 7=best) & 4.0 & 2.9 & 32 & 3.5 & 3.6 & 3.1 & 1.5 & 3.7 & 2.7 & 2.7 & 4.8 & 3.4 \\
\hline Commercial Perception of Air Transpoot Services (1=worst 7=best) & 4.3 & 4.5 & 4.5 & 4.9 & 4.2 & 4.4 & 4.2 & 3.9 & 36 & 4.4 & 5.7 & 4.8 \\
\hline Paved Roods (\% of total roads) & 55 & 57 & 25 & 56 & 38 & 32 & 36 & 76 & 30 & 52 & 82 & 50 \\
\hline
\end{tabular}


Quality - technical: Despite low road density in term of land, the quality of those roads compares favorably with upper-middle-income countries - paved roads as a percentage of total roads is $55 \%$ compared to $57 \%$ for upper-middle-income and is more than double SSA (25\%) and just above world average (50\%) and far behind OECD (82\%).

Quality - perceptions: Commercial perception of services delivered by road is one of the highest in the world with a 5.3 ranking out of 7, which is only bettered my MENA region and is significantly higher than upper middle-income countries (4.1) and OECD (4.3). Perception of port facilities is very low while perception of railroad services is quite high and only second to OECD average. Commercial perception of air transportation services (4.3) is in line with uppermiddle-income (4.5) and SSA (4.5) but lags behind OECD (5.7).

\section{Large Differences from the Benchmark}

Overall, Botswana's infrastructure performance is surprisingly very poor when compared with its benchmark income group. Table 5 below highlights some of the large differences - negative and positive - as well as areas where Botswana performs in line with benchmark. In the main access indicators, Botswana significantly underperforms upper-middle-income countries (with exception of access to improved water services) with some indicators showing performance worse than SSA (access to electricity network). An area where Botswana significantly outperforms ( $>10 \%$ of the benchmark level) is in the cost of local calls (fixed and cellular) as well as average electricity end-user prices with cheaper rates, but that could be a reflection underpricing rather than efficient markets.

Table 5: Botswana's Infrastructure Performance - Significant Deviation from Benchmark

\begin{tabular}{|c|c|c|c|c|c|}
\hline & Botswana & $\begin{array}{c}\text { Benchumark } \\
\text { Upper Middle } \\
\text { Income }\end{array}$ & SSA & World & $\begin{array}{c}\text { Botswana's } \\
\text { performance vs. } \\
\text { Benchumark } \\
\end{array}$ \\
\hline \multicolumn{6}{|l|}{ Deviation of $-10 \%$ or more from Benchmark } \\
\hline Energy: Access to Electricity Network (\% of Population) & 10 & 87 & 15 & 60 & Underperform \\
\hline ICT: Mainlines Teledensity (mainlines subscribers $/ 1000$ people) & 75 & 261 & 31 & 213 & Underperform \\
\hline ICT: Phone Faults (reported faults $/ 100$ mainlines) & 37 & 18 & 57 & 37 & Underperform \\
\hline ICT: Teledensity (total telephone subscribers $/ 1000$ people) & 372 & 635 & 99 & 501 & Underperform \\
\hline ICT: Cost of Phone Call to the US (US cents $/ 3$ minutes) & 364 & $3 \theta 5$ & 497 & 335 & Underperform \\
\hline Transport: Rail Lines Density in Terms of Land (rail-km/1000 sq km) & 18 & 31 & 3.65 & 23.12 & Underperform \\
\hline Transport: Road Density in Terms of Land (road-km/1000 sq km) & 227 & 1076 & 155.7 & 840.6 & Underperform \\
\hline Transport: Road Density in Terms of Population (road-km/1000 people) & 6.2 & 9.2 & 3.3 & 6.7 & Underperform \\
\hline Water: Access to Improved Sanitation (\% of population) & 41 & 86 & 37 & 64 & Underperform \\
\hline \multicolumn{6}{|l|}{ Deviation of between $-10 \%$ and $+10 \%$ from Benchmark } \\
\hline Transport: Paved Roads ( $\%$ of total roads) & 55 & 57 & 25 & 50 & Average \\
\hline Water: Access to Improved Water Sources ( $\%$ of population) & 95 & 93 & 64 & 80 & Average \\
\hline \multicolumn{6}{|l|}{ Deviation of $+10 \%$ or more from Benchmark } \\
\hline Electricity Average End-User Prices (US cents/kWh) - (Residentia/N on-Energy: Residential) & $4 / 3$ & $9 / 7$ & $6 / 5$ & $9 / 6$ & Outperform \\
\hline ICT: Cost of Local Phone Call (US cents/3 minutes) & 2 & 9 & 10 & 9 & Outperform \\
\hline ICT: Cost of Cellular Local Call (US cents/3 off-peak minutes) & 33 & 54 & 42 & 49 & Outperform \\
\hline
\end{tabular}




\section{Conclusion}

Surprisingly for one of the highest income countries in Sub-Saharan Africa, benchmarking indicators for Botswana show unfavorable performance in important dimensions in all four infrastructure sectors: electricity, ICT, transport, and water and sanitation. For example, access to electricity of $10 \%$ of the population is extremely low compared with its benchmark group of middle-income countries (87\%) and other geographical groups, even when spatial peculiarities of the country are taken into account. Access to improved sanitation (41\% of the population) is also only about half its benchmark level (86\%). The phone fault rates are twice higher than in the benchmark countries, although more favorable than in the SSA region as a whole. In transport and water, indicators are about on par with the benchmark. The only indicators where Botswana scores well are related to the cost of some services such as cellular phones and electricity. This suggests the need to dig deeper into the causes and consequences of this comparatively unfavorable performance of Botswana's infrastructure as a further step towards formulating appropriate infrastructure policy response. 


\section{LESOTHO $^{14}$}

Data indicators for Lesotho are much more limited than in the case of South Africa. As a result, the comparative exercise for this country is inevitably more limited in scope, focusing more on access. Indicator availability is as follows: two for electricity (access and prices), two for water and sanitation (both on access), eight on ICT, and four on transport. Nevertheless, since access indicators - critical for poverty reduction - are available for all four sectors, some broad comparisons and conclusions can be reached with appropriate caveats as indicated in the summary section on data above and the specific sector assessment for this country provided below.

\section{Energy - electricity}

Access: In this sector, only two indicators are available: access to electricity network and average end-user prices (Table 1). Lesotho's access to electricity network is one of the lowest in the world with only $6 \%$ of the population having access. This is very low in comparison to low income (Lesotho's income group) countries (31\%) and just under third of the penetration rate in SSA.

Table 1: Lesotho's Benchmarking of Electricity Performance

\begin{tabular}{|c|c|c|c|c|c|c|c|c|c|c|c|c|}
\hline Energy & Lesotho & $\begin{array}{l}\text { Benchumark } \\
\text { Low Income }\end{array}$ & SSA & $\begin{array}{c}\text { Middle } \\
\text { East and } \\
\text { Noth } \\
\text { Africa } \\
\end{array}$ & $\begin{array}{l}\text { South } \\
\text { Asia }\end{array}$ & $\begin{array}{r}\text { East } \\
\text { Asia } \\
\text { Pacific }\end{array}$ & $\begin{array}{c}\text { Latin } \\
\text { America } \\
\& \\
\text { Carihhea }\end{array}$ & $\begin{array}{c}\text { Europe \& } \\
\text { Central } \\
\text { Asia }\end{array}$ & $\begin{array}{l}\text { Middle } \\
\text { Income }\end{array}$ & $\begin{array}{l}\text { Lower } \\
\text { Middle } \\
\text { Income }\end{array}$ & $\begin{array}{l}\text { Upper } \\
\text { Middle } \\
\text { Income }\end{array}$ & World \\
\hline Access to Electricity Netwotk (\% of Population) & 6 & 31 & 15 & 88 & 31 & 54 & 79 & 99 & 85 & 82 & 87 & 60 \\
\hline $\begin{array}{l}\text { Electricity Average End-User Prices (US cents/kWh) - (ResidentialNon- } \\
\text { Residential) }\end{array}$ & $8 / 3$ & $6 / 6$ & $6 / 5$ & .. & .. & $5 / 5$ & $10 / 8$ & $6 / 6$ & 817 & $8 / 7$ & $9 / 7$ & $9 / 6$ \\
\hline
\end{tabular}

Note: Data used is from the latest observation available between 1997 and 2003.

Source: A "Research" Datahase of Infrastructure Economic Performance, Antonio Estache and Anta Goicoechea, World Bark Infrastructure Network, 0ffice of the Vice President, June 2005.

Affordability - pricing: Residential average end-user prices (US cents/kwh) are one of the most expensive at 8 cents, which is above low income and SSA at 6 cents. On the other hand nonresidential prices are one of the lowest at 3 cents compared to 6 and 5 cents for low income and SSA.

\section{Water and sanitation}

Access: Only two access indicators are available for Lesotho in this sector: access to improved water and access to improved sanitation (Table 2). Not surprisingly, Lesotho performs better than comparable groups when it comes to access to improved water sources. Around $76 \%$ of the population has access compared to around 65\% for low income and SSA. Lesotho's performance compares favorably to South Asia and East Asia Pacific regions. Moreover, there is the urban/rural divide is much narrower than other regions, with $74 \%$ of rural population having

\footnotetext{
${ }^{14}$ This case study draws almost entirely from a recent country benchmarking exercise (Bogetić 2006c).
} 
access to improved water sources compared to $56 \%$ in low income countries and $54 \%$ in SSA. About $88 \%$ of urban population has access to improved water sources, higher than low-income and SSA. In terms of access to improved sanitation, Lesotho has $37 \%$ penetration, which is similar to SSA but just under low-income countries. Other regions are far more advanced in this area with MENA at 77\%, East Asia Pacific (60\%) and Latin America and Caribbean at 77\%.

Table 2: Lesotho’s Benchmarking of Water and Sanitation Performance

\begin{tabular}{|c|c|c|c|c|c|c|c|c|c|c|c|c|}
\hline Water & Lesotho & $\begin{array}{l}\text { Benchumark } \\
\text { Low Income }\end{array}$ & SSA & $\begin{array}{l}\text { Middle } \\
\text { East and } \\
\text { Noth } \\
\text { Africa }\end{array}$ & $\begin{array}{l}\text { South } \\
\text { Asia }\end{array}$ & $\begin{array}{c}\text { East } \\
\text { Asia } \\
\text { Pacific }\end{array}$ & $\begin{array}{c}\text { Latin } \\
\text { America } \\
\& \\
\text { Caribhea } \\
\text { n }\end{array}$ & $\begin{array}{c}\text { Europe \& } \\
\text { Central } \\
\text { Asia }\end{array}$ & $\begin{array}{l}\text { Middle } \\
\text { Income }\end{array}$ & $\begin{array}{l}\text { Lower } \\
\text { Middle } \\
\text { Income }\end{array}$ & $\begin{array}{l}\text { Upper } \\
\text { Middle } \\
\text { Income }\end{array}$ & World \\
\hline Access to Improved Water Sources (\% of population) & 76 & 65 & 64 & 85 & 72 & 75 & 90 & 87 & 89 & 85 & 93 & 80 \\
\hline Access to Improved Sanitation (\% of population) & 37 & 41 & 37 & 77 & 48 & 60 & 77 & 78 & 79 & 72 & 86 & 64 \\
\hline
\end{tabular}

Note: Data used is from the latest observation available between 1997 and 2003.

Source: A "Research" Database of Infrastructure Economic Performance, Antonio Estache and Ana Goicoechea, World Bank Infrastructure Network, 0ffice of the Vice President, June 2005.

\section{Information and Communications Technology (ICT)}

Access: For ICT sector, a number of indicators are available, allowing a more nuanced analysis (Table 3). The picture with regards to teledensity is mixed with Lesotho underperforming its income group in mainline teledensity but outperforming in cellular teledensity (Table 3). Mainline teledencity is half the level of lowest of all regions and income groups - half the level of the nearest performers (low income and SSA). While cellular penetration is higher than lowincome group and South Asia but lower than all other income groups and regions.

Affordability - pricing: Surprisingly, Lesotho has one of the highest local call costs with a 3minute call costing 22 US cents. This is twice the cost in low-income, SSA and upper-middleincome countries and four times the cost in South Asia and East Asia Pacific. However both cost of international phone call to the US and cellular local call are cheaper than most other regions.

Table 3: Lesotho's Benchmarking of ICT Sector Performance

\begin{tabular}{|c|c|c|c|c|c|c|c|c|c|c|c|c|}
\hline$\underline{\text { ICT }}$ & Lesotho & $\begin{array}{l}\text { Benchumark } \\
\text { Low Income }\end{array}$ & SSA & $\begin{array}{l}\text { Middle } \\
\text { East and } \\
\text { Noth } \\
\text { Africa }\end{array}$ & $\begin{array}{l}\text { South } \\
\text { Asia }\end{array}$ & $\begin{array}{c}\text { East } \\
\text { Asia } \\
\text { Pacific }\end{array}$ & $\begin{array}{c}\text { Latin } \\
\text { America } \\
\& \\
\text { Carihhea } \\
\mathbf{n} \\
\end{array}$ & $\begin{array}{c}\text { Europe \& } \\
\text { Central } \\
\text { Asia }\end{array}$ & $\begin{array}{l}\text { Middle } \\
\text { Income }\end{array}$ & $\begin{array}{l}\text { Lower } \\
\text { Middle } \\
\text { Income }\end{array}$ & $\begin{array}{c}\text { Upper } \\
\text { Middle } \\
\text { Income }\end{array}$ & World \\
\hline Teledensity (total telephone subscribers $/ 1000$ people) & 63 & 64 & 99 & 292 & 72 & 172 & 433 & 547 & 468 & 301 & 635 & 501 \\
\hline Mairlines Teledensity (mainlines subscribers $/ 1000$ people) & 16 & 29 & 31 & 129 & 35 & 76 & 192 & 224 & 193 & 126 & 261 & 213 \\
\hline Cellular Teledensity (cellular subscribers $/ 1000$ people) & 47 & 37 & 73 & 167 & 37 & 96 & 249 & 325 & 280 & 179 & 381 & 296 \\
\hline Cost of Local Phone Call (US cents/3 minutes) & 22 & 8 & 10 & 6 & 4 & 5 & 7 & 7 & 7 & 6 & 9 & 9 \\
\hline Cost of Phone Call to the US (US cents $/ 3$ minutes) & 231 & 504 & 497 & 281 & 336 & 450 & 325 & 326 & 309 & 314 & 305 & 335 \\
\hline Cost of Cellular Local Call (US cents/3 off-peak minutes) & 26 & 40 & 42 & 52 & 17 & 42 & 57 & 40 & 49 & 44 & 54 & 49 \\
\hline Phone Faults (reported faults/100 mainlines) & 75 & 64 & 57 & 23 & 97 & 39 & 24 & 34 & 25 & 33 & 18 & 37 \\
\hline Unmet Demand ( $\%$ of main telephone lines in operation) & 73 & 47 & 50 & 26 & 24 & 13 & 17 & 8 & 12 & 20 & 4 & 21 \\
\hline
\end{tabular}

Note: Data used is from the latest observation available between 1997 and $2 \theta 03$.

Source: A "Research" Datahase of Infrastructure Economic Performance, Antonio Estache and Ana Goicoechea, World Bank Infrastructure Network, Office of the Vice President, June 2005. 
Quality - technical: Reported faults per 100 telephone mainlines are very high in Lesotho at $75 \%$, much higher than low-income (64) and SSA (57) but lower much lower than the South Asia where $97 \%$ faults are reported. Unmet demand is also very high with around $73 \%$ of people registered for connection not being connected. 


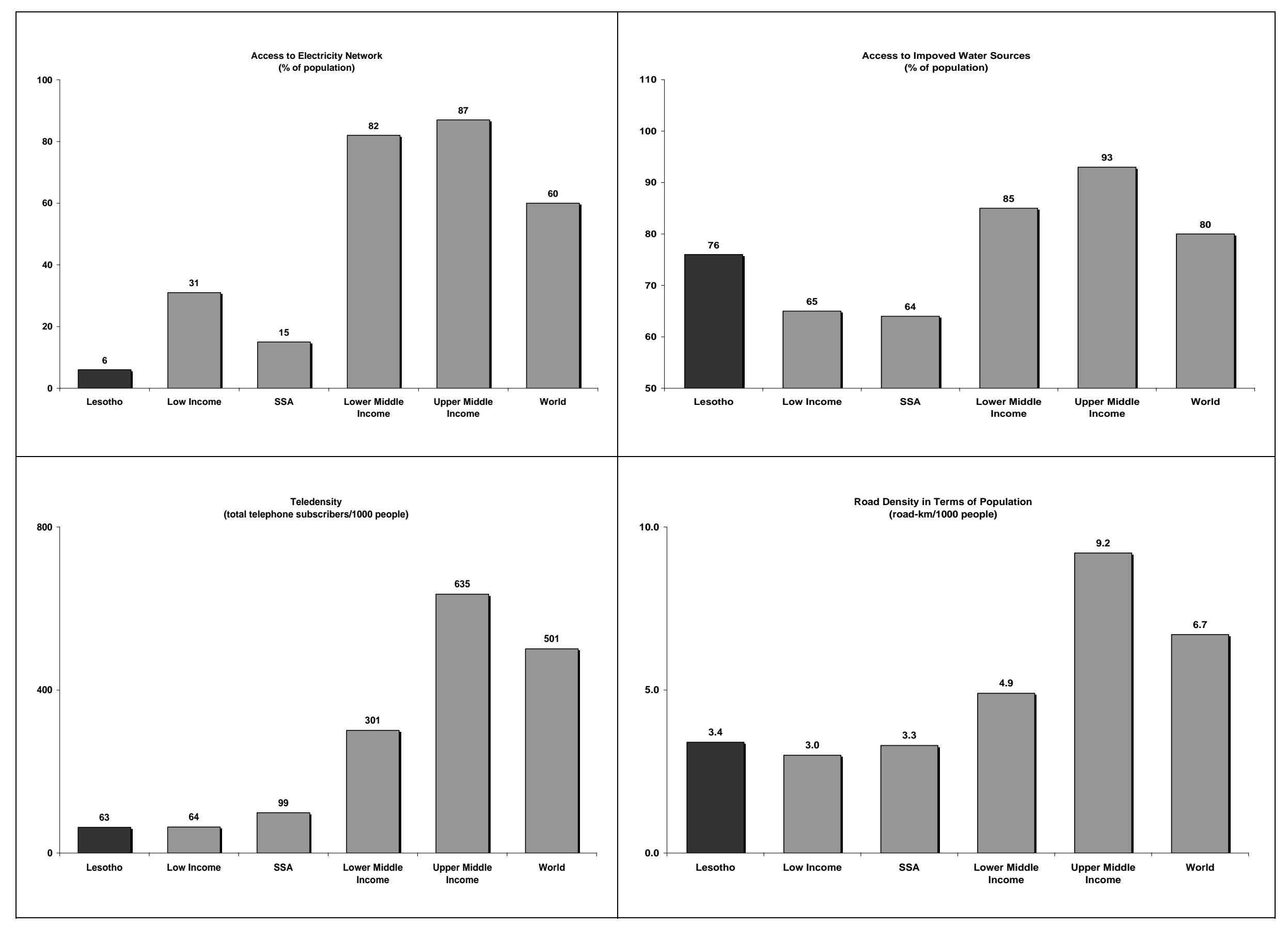




\section{Transport}

Access: Road density in terms of population (road-kilometers per 1,000 people) is slightly higher than the low-income average and similar to SSA but is only a third of upper-middleincome levels and half the world average. Road density in terms of population is also higher than low-income and SSA countries but far behind all other regions and income groups with a world average being four times higher.

Table 4: Benchmarking Lesotho’s Performance in the Transport Sector

\begin{tabular}{|c|c|c|c|c|c|c|c|c|c|c|c|c|}
\hline Transport & Lesotho & $\begin{array}{l}\text { Benchumark } \\
\text { Low Income }\end{array}$ & SSA & $\begin{array}{l}\text { Middle } \\
\text { East and } \\
\text { Noth } \\
\text { Africa }\end{array}$ & $\begin{array}{c}\text { South } \\
\text { Asia }\end{array}$ & $\begin{array}{c}\text { East } \\
\text { Asia } \\
\text { Pacific }\end{array}$ & $\begin{array}{c}\text { Latin } \\
\text { America } \\
\& \\
\text { Caribbea } \\
\text { n } \\
\end{array}$ & $\begin{array}{c}\text { Europe \& } \\
\text { Central } \\
\text { Asia }\end{array}$ & $\begin{array}{l}\text { Middle } \\
\text { Income }\end{array}$ & $\begin{array}{l}\text { Lower } \\
\text { Middle } \\
\text { Income }\end{array}$ & $\begin{array}{l}\text { Upper } \\
\text { Middle } \\
\text { Income }\end{array}$ & World \\
\hline Road Density in Terms of Population (road-km/1000 people) & 3.4 & 3.0 & 3.3 & 4.8 & 2.4 & 4.2 & 5.7 & 8.6 & 7.0 & 4.9 & 9.2 & 6.7 \\
\hline Road Density in Terms of Land (road-km/1000 sq km) & 195.7 & 181 & 155.7 & 608.9 & 544.6 & 276.4 & 712.7 & 580.3 & 702 & 327.7 & 1076.4 & 840.6 \\
\hline Travel Time to Work in Main Cities (minutes/one-way work trip) & 15 & 33 & 34 & 25 & 27 & 36 & 29 & 29 & 29 & 40 & 29 & 31 \\
\hline Paved Roads ( $\%$ of total roads) & 18 & 30 & 25 & 56 & 38 & 32 & 36 & 76 & 52 & 47 & 57 & 50 \\
\hline
\end{tabular}

Note: Data used is from the latest observation available between 1997 and 2003.

Source: A "Research" Database of Infrastructure Economic Performance, Antonio Estache and Ana Goicoechea, World Bank Infrastructure Network, Office of the Vice President, June 2005.

Quality - technical: Only 18\% of all roads are paved in Lesotho, which compares poorly to all other regions and income groups. Low-income countries have 30\% paved roads, SSA (25\%), MENA (56\%) and upper-middle-income countries have $57 \%$ of all roads paved.

Quality - perceptions: Despite low levels of paved roads, average time to work in main cities is only 15 minutes, one of the fastest times and at least half the amount taken in low-income, SSA, East Asia Pacific and upper-middle-income countries.

\section{Large Differences from the Benchmark}

Overall, Lesotho's performance in relation to its income group is mixed with strong performance in access to improved water (both rural and urban) and in transport density (both in terms of roads and land) and cellular teledensity but lags far behind in access to electricity network and mainline teledensity (Table 5). Technical quality is also poor (paved roads) while cost of international and local cellular calls are reasonably priced. 
Table 5: Lesotho's Infrastructure Performance - Significant Deviation from Benchmark

\begin{tabular}{|c|c|c|c|c|c|}
\hline & Lesotho & $\begin{array}{l}\text { Benchumark } \\
\text { Low Income }\end{array}$ & SSA & World & $\begin{array}{c}\text { Lesotho's } \\
\text { performance vs. } \\
\text { Benchumark }\end{array}$ \\
\hline Deviation of $-10 \%$ or more from Benchmark & & & & & \\
\hline Energy: Access to Electricity Network (\% of Population) & 6 & 31 & 15 & 60 & Underperform \\
\hline Electricity Average End-User Prices (US cents/kWh) - (Residential/N on-Energy: Residential) & $8 / 3$ & $6 / 6$ & $6 / 5$ & $9 / 6$ & Underperform \\
\hline ICT: Mainlines Teledensity (mainlines subscribers $/ 1000$ people) & 16 & 29 & 31 & 213 & Underperform \\
\hline ICT: Cost of Local Phone Call (US cents/3 minutes) & 22 & $s$ & 10 & 9 & Underperform \\
\hline ICT: Phone Faults (reported faults/100 mainlines) & 75 & 64 & 57 & 37 & Underperform \\
\hline Transport: Paved Roads (\% of total roads) & 18 & 30 & 25 & 50 & Underperform \\
\hline Water: Access to Improved Sanitation ( $\%$ of population) & 37 & 41 & 37 & 64 & Underperform \\
\hline $\begin{array}{l}\text { Deviation of between }-10 \% \text { and }+10 \% \text { from Benchmark } \\
\text { ICT: Teledensity (total telephone subscribers } / 1000 \text { people) }\end{array}$ & 63 & 64 & 99 & 501 & Average \\
\hline Deviation of $+10 \%$ or more from Benchmark & & & & & \\
\hline ICT: Cellular Teledensity (cellular subscribers $/ 1000$ people) & 47 & 37 & 73 & 296 & Outperform \\
\hline ICT: Cost of Phone Call to the US (US cents $/ 3$ minutes) & 231 & 504 & 497 & 335 & Outperform \\
\hline ICT: Cost of Cellular Local Call (US cents/3 off-peak minutes) & 26 & 40 & 42 & 49 & Outperform \\
\hline Water: Access to Improved Water Sources (\% of population) & 76 & 65 & 64 & 80 & Outperform \\
\hline Transport: Road Density in Terms of Population (road-kn/1000 people) & 3.4 & 3.0 & 3.3 & 6.7 & Outperform \\
\hline Transport: Road Density in Terms of Land (road-km/1000 sq km) & 196 & $\mathbf{I S I}$ & 155.7 & 840.6 & Outperform \\
\hline Transport: Trave1 Time to Work in Main Cities (minutes/one-way work trip) & 15 & 3.3 & 34 & 31 & Outperform \\
\hline
\end{tabular}




\section{Conclusion}

In sum, we benchmarked Lesotho's infrastructure performance using available comparative indicators of various dimensions of performance. The indicators come from the recent World Bank research data base specifically developed for this purpose. The results are revealing of the several major, comparative deficiencies in infrastructure performance in Lesotho: (i) extremely low access to electricity and its affordability; (ii) poor coverage, quality and the cost of local (non-cellular) telephony; (iii) poor quality of roads, and (iv) very low access of the population to improved sanitation. Infrastructure service delivery in these areas is clearly well below what would be expected on average for a country in Lesotho's income group.

These infrastructure shortfalls are likely to adversely affect not only the welfare of the poor but also the cost competitiveness and growth prospects of a range of economic sectors (e.g., tourism, trade) that depend critically on a stable and competitive supply of basic infrastructure service. As such, these shortfalls are also indicative of the infrastructure sectors and performance dimensions that need improvement if Lesotho is to catch up with competitive performance of its peer group of countries. Within the SACU sub-region, Lesotho's infrastructure shortfalls are also likely to constrain its regional economic integration in several areas (e.g., Southern Africa power pool, road network) that are important for long-term economic prosperity. Finally, this simple, international comparison of Lesotho's infrastructure performance should, of course, be combined with more in-depth, sector analyses for a more complete picture of the overall infrastructure performance. Taken together, such analyses could provide policymakers in Lesotho a useful guide to the areas of infrastructure performance requiring urgent attention. 


\section{NAMIBIA}

Indicator data in the comparative database for Namibia are only slightly more limited than in the case of South Africa, but much more exhaustive than in the case of Swaziland and Lesotho. As a result, the comparisons and discussions of Namibia provide for a more in-depth comparison, similar to that carried out for South Africa. Nevertheless, the same broad caveats in interpreting the data outlined in the summary section apply here as well. Indicator data are limited to five for electricity (access, prices, and quality), three for water and sanitation (two on access and one on commercial perception of water service), twelve for ICT, and ten on transport.

\section{Energy - electricity}

Access: Namibia's access to electricity network is significantly lower than its income group lower-middle-income - but slightly higher than in SSA (Table 1). Only $20 \%$ of the population has access to electricity compared to $82 \%$ for lower-middle-income countries and $15 \%$ for SSA. Namibia's access is lower than all other income groups as well as regions.

Table 1: Benchmarking Namibia's Performance in the Electricity Sector

\begin{tabular}{|c|c|c|c|c|c|c|c|c|c|c|c|c|c|}
\hline Energy & Namihia & $\begin{array}{c}\text { Main } \\
\text { Benchumark } \\
\text { Lower } \\
\text { Middle } \\
\text { Income }\end{array}$ & SSA & $\begin{array}{l}\text { Middle } \\
\text { East and } \\
\text { Noth } \\
\text { Africa }\end{array}$ & $\begin{array}{l}\text { South } \\
\text { Asia }\end{array}$ & $\begin{array}{r}\text { East } \\
\text { Asia } \\
\text { Pacific }\end{array}$ & $\begin{array}{c}\text { Latin } \\
\text { America } \\
\& \\
\text { Carihbean }\end{array}$ & $\begin{array}{c}\text { Europe \& } \\
\text { Central } \\
\text { Asia }\end{array}$ & $\begin{array}{l}\text { Low } \\
\text { Income }\end{array}$ & $\begin{array}{l}\text { Middle } \\
\text { Income }\end{array}$ & $\begin{array}{r}\text { Upper } \\
\text { Middle } \\
\text { Income }\end{array}$ & $\begin{array}{l}\text { High } \\
\text { Income } \\
\text { OECD }\end{array}$ & World \\
\hline Access to Electricity Network (\% of Population) & 20 & 82 & 15 & 88 & 31 & 54 & 79 & 99 & 31 & 85 & 87 & & 60 \\
\hline Energy Use Per PPP GDP (kg of oil equivalent/1000 PPP dollars, Constant 2000) & 98 & 242 & 364 & 249 & 184 & 212 & 207 & 375 & 374 & 246 & 249 & 188 & 275 \\
\hline $\begin{array}{l}\text { Electricity Average End-User Prices (US cents/WWh)- } \\
\text { (Residential/Non-Residential) }\end{array}$ & $4 / 2$ & $8 / 7$ & $6 / 5$ & .. & .. & $5 / 5$ & $10 / 8$ & $6 / 6$ & $6 / 6$ & $8 / 7$ & $9 / 7$ & $13 / 6$ & $9 / 6$ \\
\hline Commercial Perception of Electricity service (1=worst 7=best) & 5.6 & 4.2 & 4.3 & 5.1 & 26 & 4.3 & 4.2 & 4.8 & 28 & 4.7 & 5.2 & 6.3 & 5.0 \\
\hline Contmercial Perception of Public Agency Electricity Provider ( $1=$ worst $7=b e s t)$ & 6.3 & 5.0 & 4.3 & 60 & 3.8 & 5.0 & 4.8 & 4.8 & 4.0 & 5.2 & 5.3 & 5.3 & 4.8 \\
\hline
\end{tabular}

Note: Data used is from the latest observation available between 1997 and 2003.

Source: A "Research" Database of Infrastructure Economic Performance, Antonio Estache and Anta Goicoechea, World Bark Infrastructure Network, 0ffice of the Vice President, June 2005.

Affordability - pricing: Average end-user prices (US cents/kwh) in Namibia are cheaper compared to all other income groups and regions. Residential end-user prices are 4 cents/kwh compared to 8 cents for lower-middle-income and 6 cents in SSA and low-income countries. The most expensive rates are found in high-income OECD countries at 13 cents. Non-residential end-user prices are a mere 2 cents in Namibia, 7 cents in lower-middle-income and 5 cents in SSA. The most expensive region is Latin America and Caribbean (8 cents).

Quality - perception: In terms of commercial perception of electricity service, Namibia gets a rating of 5.6 out of 7, which is much higher than 4.2 in lower-middle-income countries and 4.3 in SSA and is only bettered by 6.3 in high-income OECD countries. The world average is 5 . Namibia's performance is even better when it comes to commercial perception of public agency electricity provider. It has the highest rating of all regions and income groups at 6.3. 


\section{Water and sanitation}

Access: Overall access to water is slightly below lower middle-income countries but better than regional comparison - SSA (Table 2). Around $80 \%$ of the Namibian population has access to improved water sources compared to $85 \%$ in lower-middle-income and 64\% in SSA. Namibia outperforms South Asia, East Asia regions and low income countries. High-income OECD countries have the highest access rate (99\%) closely followed by upper-middle-income (93\%). In terms of the urban/rural mix, Namibia does well in urban areas with rural areas lagging behind. Urban penetration is one of the highest in the world at 98\% (only bettered by OECD countries) while rural penetration is only $72 \%$, slightly below lower-middle-income countries (76\%). However, access to improved sanitation is one of the worst in the world with only $30 \%$ of the population, compared to $72 \%$ in lower-middle-income countries and falls even short of $37 \%$ in SSA. The overall figure actually masks the stark reality of urban/rural divergence with only $14 \%$ of rural population having access to improved sanitation compared to $66 \%$ of households in urban areas. Once again rural performance is very low in comparison to all other income groups and regions and is only half the penetration rate of SSA - the nearest comparison. However urban penetration is slightly better than SSA.

Table 2: Benchmarking Namibia’s Performance in the Water and Sanitation Sector

\begin{tabular}{|c|c|c|c|c|c|c|c|c|c|c|c|c|c|}
\hline Watel' & Nambiaia & $\begin{array}{c}\text { Main } \\
\text { Benchumark } \\
\text { Lower } \\
\text { Middle } \\
\text { Income }\end{array}$ & SSA & $\begin{array}{l}\text { Middle } \\
\text { East and } \\
\text { Noth } \\
\text { Africa }\end{array}$ & $\begin{array}{l}\text { South } \\
\text { Asia }\end{array}$ & $\begin{array}{l}\text { East } \\
\text { Asia } \\
\text { Pacific }\end{array}$ & $\begin{array}{l}\text { Latin } \\
\text { America } \\
\& \\
\text { Carihhean }\end{array}$ & $\begin{array}{c}\text { Europe \& } \\
\text { Centryl } \\
\text { Asia }\end{array}$ & $\begin{array}{l}\text { Low } \\
\text { Income }\end{array}$ & $\begin{array}{l}\text { Middle } \\
\text { Income }\end{array}$ & $\begin{array}{l}\text { Ipper } \\
\text { Middle } \\
\text { Income }\end{array}$ & $\begin{array}{l}\text { High } \\
\text { Income } \\
\text { OECD }\end{array}$ & World \\
\hline Access to Imptoved Water Sources (\% of populdation) & 80 & 85 & 64 & 85 & 72 & 75 & 90 & 87 & 65 & 89 & 93 & 99 & 80 \\
\hline Access to Improved Sanitation (\% of population) & 30 & 72 & 37 & 77 & 48 & 60 & 77 & 78 & 41 & 79 & 86 & 100 & 64 \\
\hline Conmercial Percention of Water Service (1=worst $7=$ hest) & 6.2 & 4.8 & 4.2 & 56 & 4.1 & 4.8 & 4.7 & 4.6 & 4.0 & 4.9 & 50 & 5.2 & 4.7 \\
\hline
\end{tabular}

Mote: Data wed isfom the latest observation available betwen 1997 and 2093.

Source: A "Research" Datahase of Infrystructure Economic Performance, Antonio Estache and Ana Goicoechea, World Bank Infrastructure Network, Office of the Yice President, June 2005.

Quality-perception: Commercial perception of water services is very high and is the highest when compared to all income groups and regions. Perception ranks at 6.2 out of 7 for Namibia, 4.8 for lower-middle-income-countries, 4.2 for SSA and 5.2 in high-income OECD countries. The high ranking is not surprising but beating OECD perception is a surprise and may indicate an "urban bias" in the conduct of the survey. 


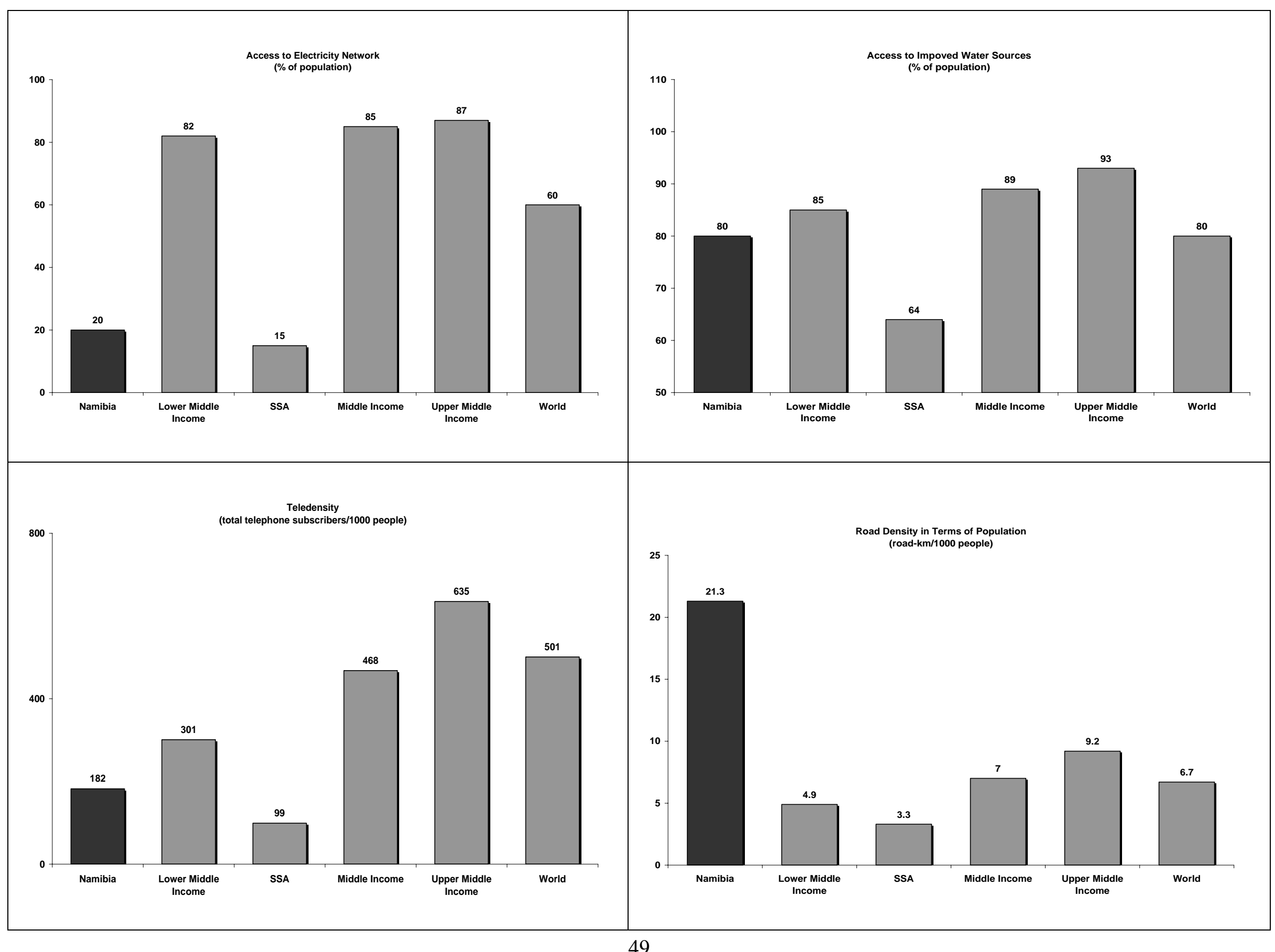




\section{Information and Communications Technology (ICT)}

Access: In terms of mainline teledensity, Namibia underperforms its income group but does significantly better than SSA (Table 3). Mainline teledensity is 66 (subscribers per 1000 people), which is half the lower-middle-income group rate but twice as much as SSA. When compared to other regions, Namibia lags behind MENA, East Asia and Latin America and Caribbean but performs much better than South Asia (35). Cellular teledensity (116) is much better but still behind lower-middle-income (179) and higher-income groups.

Affordability - pricing: The cost of a 3-minute local call in US cents is 4 cents in Namibia. This is one of the cheapest rates when compared to other income and regional groups and only matched by a similar rate in South Asia. High-income countries have the most expensive local call rates at 15 cents. However the cost of a 3-minute international call to the US is very high at $\$ 4.28$ compared to $\$ 3.14$ for lower-middle-income countries and $\$ 1.28$ for high-income OECD. The most expensive region is SSA and most expensive income group is low-income, both costing around $\$ 5$ for a 3-minute call to the US. In terms of local cellular calls, Namibia has one of the lowest rates (30 cents/3 off-peak minutes) and is only bettered by a 17 cents charge in South Asia. High-income OECD countries have the highest charges for local cellular calls (57 cents) and the world average rate is 49 cents.

Table 3: Benchmarking Namibia's Performance in the ICT Sector

\begin{tabular}{|c|c|c|c|c|c|c|c|c|c|c|c|c|c|}
\hline$\underline{\text { ICT }}$ & Namthia & $\begin{array}{c}\text { Main } \\
\text { Benchutark } \\
\text { Lower } \\
\text { Middle } \\
\text { Income } \\
\end{array}$ & SSA & $\begin{array}{l}\text { Middle } \\
\text { East and } \\
\text { Noth } \\
\text { Africa }\end{array}$ & $\begin{array}{l}\text { South } \\
\text { Asia }\end{array}$ & $\begin{array}{c}\text { East } \\
\text { Asia } \\
\text { Pacific }\end{array}$ & $\begin{array}{c}\text { Latin } \\
\text { America } \\
\& \\
\text { Carihbean }\end{array}$ & $\begin{array}{c}\text { Europe \& } \\
\text { Central } \\
\text { Asia }\end{array}$ & $\begin{array}{l}\text { Low } \\
\text { Income }\end{array}$ & $\begin{array}{l}\text { Middle } \\
\text { Income }\end{array}$ & $\begin{array}{l}\text { Upper } \\
\text { Middle } \\
\text { Income }\end{array}$ & $\begin{array}{c}\text { High } \\
\text { Income } \\
\text { OECD }\end{array}$ & World \\
\hline Teledensity (total telephone subscribers/1000 people) & 182 & 301 & 99 & 292 & 72 & 172 & 433 & 547 & 64 & 468 & 635 & 1393 & 501 \\
\hline Mairlines Teledensity (mainlines subscribers 11000 people) & 66 & 126 & 31 & 129 & 35 & 76 & 192 & 224 & 29 & 193 & 261 & 572 & 213 \\
\hline Cellular Teledensity (cetlular subscribers/1000 people) & 116 & 179 & 73 & 167 & 37 & 96 & 249 & 325 & 37 & 280 & 381 & 827 & 296 \\
\hline Cost of Local Phone Call(US cents/3 ninutes) & 4 & 6 & 10 & 6 & 4 & 5 & 7 & 7 & 8 & 7 & 9 & 15 & 9 \\
\hline Cost of Phone Call to the US (US cents/3 minutes) & 428 & 314 & 497 & 281 & 336 & 450 & 325 & 326 & 504 & 309 & 305 & 128 & 335 \\
\hline Cost of Cellular Local Call (US cents/3 off-peak minutes) & 30 & 44 & 42 & 52 & 17 & 42 & 57 & 40 & 40 & 49 & 54 & 57 & 49 \\
\hline $\begin{array}{l}\text { Conmercial Perception of Telephone Fax Infrastructure quality (1=worst } \\
7=\text { best) }\end{array}$ & 5.1 & 4.9 & 4.3 & 5.8 & 4.3 & 5.2 & 4.6 & 5.3 & 3.4 & 5.3 & 5.6 & 6.6 & 5.5 \\
\hline $\begin{array}{l}\text { Conmercial Perception of Availability of Mobile or Cellulat Telephone } \\
(1=\text { worst } 7=\text { best })\end{array}$ & 5.9 & 5.8 & 5.7 & 5.9 & 59 & 5.7 & 5.5 & 60 & 5.0 & 5.9 & 6.0 & 6.7 & 6.1 \\
\hline Commercial Perception of Internet Access in Schools (1=worst 7=best) & 3.4 & 3.0 & 2.8 & 3.5 & 2.7 & 3.4 & 2.8 & 3.7 & 2.1 & 3.4 & 3.8 & 5.4 & 4.0 \\
\hline Contumercial Perception of Postal Efficiency (1=worst $7=$ best) & 4.1 & 3.5 & 3.7 & 4.9 & 3.3 & 4.2 & 3.1 & 4.3 & 3.1 & 3.9 & 4.4 & 6.2 & 4.6 \\
\hline Phone Faults (reported faults $/ 100$ mainlines) & 40 & 33 & 57 & 23 & 97 & 39 & 24 & 34 & 64 & 25 & 18 & 11 & 37 \\
\hline Unmet Demand (\% of main telephone lines in operation) & 2 & 20 & 50 & 26 & 24 & 13 & 17 & 8 & 47 & 12 & 4 & 0 & 21 \\
\hline
\end{tabular}

Note: Data used is from the latest observation available between 1997 and 2083.

Source: A "Research" Datahase of Infrastructure Economic Performance, Antonio Estache and Ana Goicoechea, World Bank Infrastructure Network, 0ffice of the Vice President, June 2005. 
Quality - technical: Namibia's reported faults per 100 telephone mainlines are high (40) compared to its income group (33) but much better than SSA (57). The highest reported faults are to be found in South Asia (97) and the lowest in high-income OECD countries (11).

Quality - perceptions: Commercial perception of telephone infrastructure in Namibia (5.1) is higher than lower-middle-income countries (4.9) and SSA (4.3) but far behind high-income OECD countries (6.6). Perception of mobile phone availability (5.9) is higher than that for telephone infrastructure. This is the case for all regions and income groups. Namibia does slightly better than its income group but is slightly below world average (6.1). And finally, commercial perception of internet access in schools and postal efficiency rank higher than both relevant income group and geographical comparison.

\section{Transport}

Access: Road density in terms of population (road-kilometers per 1,000 people) is one of the highest in the world with only a handful of countries having higher density (Table 4). Namibia's density is 21 road-km per 1,000 people compared to 4.9 for lower middle income countries and almost seven times as much as density in SSA. High-income OECD counties come closest to Namibia's density with 17 road-km. The reverse is true when one looks at road density in terms of land (road-kilometers per 1,000 sq $\mathrm{km}$ ) with Namibia being the least dense relative to income and regional groups looked at. This is likely to be a reflection of a very large country with small population concentrated in small areas.

Table 4: Benchmarking Namibia’s Performance in the Transport Sector

\begin{tabular}{|c|c|c|c|c|c|c|c|c|c|c|c|c|c|}
\hline Transport & Namihia & $\begin{array}{c}\text { Main } \\
\text { Benchumark } \\
\text { Lower } \\
\text { Middle } \\
\text { Income } \\
\end{array}$ & SSA & $\begin{array}{l}\text { Middle } \\
\text { East and } \\
\text { Noth } \\
\text { Africa }\end{array}$ & $\begin{array}{l}\text { South } \\
\text { Asia }\end{array}$ & $\begin{array}{r}\text { East } \\
\text { Asia } \\
\text { Pacific }\end{array}$ & $\begin{array}{c}\text { Latin } \\
\text { America } \\
\& \\
\text { Carihbean }\end{array}$ & $\begin{array}{c}\text { Europe \& } \\
\text { Central } \\
\text { Asia }\end{array}$ & $\begin{array}{l}\text { Low } \\
\text { Income }\end{array}$ & $\begin{array}{l}\text { Middle } \\
\text { Income }\end{array}$ & $\begin{array}{r}\text { Upper } \\
\text { Middle } \\
\text { Income }\end{array}$ & $\begin{array}{c}\text { High } \\
\text { Income } \\
\text { OECD }\end{array}$ & World \\
\hline Road Density in Terms of Population (road-km/1000 people) & 21.3 & 4.9 & 3.3 & 4.8 & 2.4 & 4.2 & 5.7 & 8.6 & 3.0 & 7.0 & 9.2 & 17.3 & 6.7 \\
\hline Road Density in Terms of Land (road-km/1000 sq km) & 51.3 & 327.7 & 155.7 & 608.9 & 544.6 & 276.4 & 712.7 & 580.3 & 181 & 702 & 1076.4 & 1340.4 & 840.6 \\
\hline Rail Lines Density in Terms of Land (rail-km/1000 sq km) & 2.89 & 15.2 & 3.65 & 5.5 & 18.79 & 8.85 & 14.78 & 33.22 & 9.33 & 23.26 & 31.33 & 46.22 & 23.12 \\
\hline Travel Time to Work in Main Cities (minutes/one-way wook trip) & 20 & 40 & 34 & 25 & 27 & 36 & 29 & 29 & 33 & 29 & 29 & 32 & 31 \\
\hline $\begin{array}{l}\text { Conmercial Perception of Services Delivered by Road Department/Public } \\
\text { Wotks ( } 1=\text { worst } 7=\text { best) }\end{array}$ & 5.9 & 4.2 & 3.7 & 5.5 & 3.9 & 4.4 & 4.0 & 3.6 & 3.4 & 4.1 & 4.1 & 4.3 & 4.0 \\
\hline Conmercial Perception of Air Transport Services (1=worst $7=$ best) & 4.7 & 4.2 & 4.5 & 4.9 & 4.2 & 4.4 & 4.2 & 3.9 & 3.6 & 4.4 & 4.5 & 5.7 & 4.8 \\
\hline Paved Roads (\% of total roads) & 13 & 47 & 25 & 56 & 38 & 32 & 36 & 76 & 30 & 52 & 57 & 82 & 50 \\
\hline
\end{tabular}

Note: Data used is from the latest observation available between 1997 and 2003.

Source: A "Research" Datahase of Infrastructure Economic Performance, Antonio Estache and Ana Goicoechea, World Bank Lufrastructure Network, Office of the Vice President, June 2005.

Quality - technical: Namibia has one of the lowest paved roads as a percentage of total roads. Only $13 \%$ of roads are paved with is a third of the level in lower-middle-income countries and 
almost half the SSA average. The highest proportion of paved roads is in high-income OECD countries $(82 \%)$.

Quality - perceptions: Despite low levels road density in terms of land and even lower quality of roads (in terms of paved road percentage), commercial perception of services delivered by road is one of the highest in the world and higher than all the income and regional groups we looked at. Commercial perception of port facilities is also very high (5.0 out of 7) compared to 3.5 in lower-middle-income countries and only bettered by 5.4 rating in high-income OECD countries. Namibia also ranks higher than its income and regional group when looking at commercial perception of railroad services and air transport services. Travel time to work in main cities is one of the lowest in the world at 20 minutes - half the time it takes in lowermiddle-income countries.

\section{Large Differences from the Benchmark}

Overall, Namibia's infrastructure performance leaves much to be desired relative to its income group, which highlights some of the large differences - negative and positive - as well as areas where Namibia performs in line with benchmark (Table 5). In the major categories (access), Namibia is far behind (with the exception of access to improved water sources) its lower-middleincome group. Strong performance by Namibia is noted in transport sector (road density in terms of population) as well as lower travel to work. And similar with other countries in the region, Namibia's also performs well in terms of affordability in the form of cheaper electricity or local phone calls, but again, this could be the result of underpricing.

Table 5: Namibia's Infrastructure Performance - Significant Deviation from Benchmark

\begin{tabular}{|c|c|c|c|c|c|}
\hline & Namibia & $\begin{array}{c}\text { Benchumark } \\
\text { Lower Middle } \\
\text { Income }\end{array}$ & SSA & World & $\begin{array}{c}\text { Namibia's } \\
\text { performance vs. } \\
\text { Benchumark }\end{array}$ \\
\hline \multicolumn{6}{|l|}{ Deviation of $-10 \%$ or more from Benchmark } \\
\hline Energy: Access to Electricity Network (\% of Population) & 20 & 82 & 15 & 60 & Underperform \\
\hline ICT: Cost of Phone Call to the US (US cents $/ 3$ minutes) & 428 & 314 & 497 & 335 & Underperform \\
\hline ICT: Mainlines Teledensity (mainlines subscribers $/ 1000$ people) & 66 & 126 & 31 & 213 & Underperform \\
\hline ICT: Phone Faults (reported faults $/ 100$ mainlines) & 40 & 33 & 57 & 37 & Underperform \\
\hline ICT: Teledensity (total telephone subscribers $/ 1000$ people) & 182 & $3 \theta 1$ & 99 & 501 & Underperform \\
\hline Transport: Paved Roads (\% of total roads) & 13 & 47 & 25 & 50 & Underperform \\
\hline Transport: Rail Lines Density in Terms of Land (rail-km/1000 sq km) & 2.9 & 15 & 3.7 & 23.1 & Underperform \\
\hline Transport: Road Density in Terms of Land (road-km/1000 sq km) & 51 & 328 & 156 & 841 & Underperform \\
\hline Water: Access to Improved Sanitation (\% of population) & 30 & 72 & 37 & 64 & Underperform \\
\hline \multicolumn{6}{|l|}{ Deviation of between $-10 \%$ and $+10 \%$ from Benchmark } \\
\hline Water: Access to Improved Water Sources (\% of population) & 80 & $8 s$ & 64 & 80 & Average \\
\hline \multicolumn{6}{|l|}{ Deviation of $+10 \%$ or more from Benchmark } \\
\hline Electricity Average End-User Prices (US cents/kWh) - (Residentia//Non-Energy: Residential) & $4 / 2$ & $8 / 7$ & $6 / 5$ & $9 / 6$ & Outperform \\
\hline ICT: Cost of Cellular Local Call (US cents/3 off-peak minutes) & 30 & 44 & 42 & 49 & Outperform \\
\hline ICT: Cost of Local Phone Call (US cents $/ 3$ minutes) & 4 & 6 & 10 & 9 & Outperform \\
\hline Transport: Road Density in Terms of Population (road-km/1000 people) & 21.3 & 4.9 & 3.3 & 6.7 & Outperform \\
\hline Transport: Trave1 Time to Work in Main Cities (minutes/one-way work trip) & 20 & $4 \theta$ & 34 & 31 & Outperform \\
\hline
\end{tabular}




\section{Conclusion}

Perhaps surprisingly as one of the better off countries in the SACU region, benchmarking indicators for Namibia show unfavorable performance in several dimensions of infrastructure performance, suggesting important infrastructure deficiencies. In some ways, the overall picture is not dissimilar to that of Botswana, a SACU country with even higher income level but with clear gaps in performance in some infrastructure sectors. In Namibia, ICT and sanitation indicators also lag significantly behind the benchmarks. Strong dimensions of Namibia's infrastructure performance appear to be the cost of some ICT services and the roads density in terms of population. 


\section{SWAZILAND}

As in the case of other four smaller SACU countries, data for Swaziland are more limited than in the case of South Africa. As a result, the comparisons and discussions are limited to those indicators readily available for Swaziland. Nevertheless, some broad conclusions can be drawn, especially with respect to access indicators, which are available for all four sectors. Importantly, these are also indicators that are particularly important in gauging the success in reaching the poor in terms of delivery of basic infrastructure services. Indicator data are limited to two for electricity (access and prices), two for water and sanitation (both on access), eight for ICT, and two on transport (road density in terms of population and land). The lack of data on quality and pricing does not allow any discussion of these important indicators of performance.

\section{Energy - electricity}

Access: According to the two indicators available in this dimension, Swaziland's access to electricity network is among the lowest in the world at $20 \%$ of the population (Table 1 ). This is only a quarter of its benchmark income group (lower-middle-income countries) and is only higher than the average for the SSA (15\%). Other world regions such as MENA (88\%), Latin America and Caribbean (79\%) and Europe and Central Asia (99\%) enjoy much high access rates. Swaziland is also ranked even lower than low-income countries with access levels of $31 \%$.

Table 1: Benchmarking Swaziland's Performance in the Electricity Sector

\begin{tabular}{|c|c|c|c|c|c|c|c|c|c|c|c|c|c|}
\hline Ener'gy & Swaziland & $\begin{array}{c}\text { Main } \\
\text { Benchumark } \\
\text { Lower } \\
\text { Middle } \\
\text { Income } \\
\end{array}$ & SSA & $\begin{array}{l}\text { Middle } \\
\text { East and } \\
\text { Noth } \\
\text { Africa }\end{array}$ & $\begin{array}{l}\text { South } \\
\text { Asia }\end{array}$ & $\begin{array}{c}\text { East } \\
\text { Asia } \\
\text { Pacific }\end{array}$ & $\begin{array}{c}\text { Latin } \\
\text { America } \\
\& \\
\text { Caribhean }\end{array}$ & $\begin{array}{c}\text { Europe \& } \\
\text { Central } \\
\text { Asia }\end{array}$ & $\begin{array}{l}\text { Low } \\
\text { Income }\end{array}$ & $\begin{array}{l}\text { Middle } \\
\text { Income }\end{array}$ & $\begin{array}{l}\text { Upper } \\
\text { Middle } \\
\text { Income }\end{array}$ & $\begin{array}{l}\text { High } \\
\text { Income } \\
\text { OECD }\end{array}$ & World \\
\hline Access to Electricity Netwook (\% of Population) & 20 & 82 & 15 & 88 & 31 & 54 & 79 & 99 & 31 & 85 & 87 & .. & 60 \\
\hline $\begin{array}{l}\text { Electricity Average End-Jser Prices (US cents/kWh). } \\
\text { (ResidentialNon-Residential) }\end{array}$ & $4 / 3$ & 817 & 615 & .. & . & $5 / 5$ & $10 / 8$ & $6 / 6$ & $6 / 6$ & $8 / 7$ & $9 / 7$ & $13 / 6$ & $9 / 6$ \\
\hline
\end{tabular}

Note: Data used is from the latest observation available between 1997 and 2003.

Source: A "Research" Datahase of Infrastructure Economic Performance, Antonio Estache and Ana Goicoechea, World Bank Infrastructure Network, Office of the Vice President, Jure 2005.

Affordability - pricing: Swaziland's average end user prices (US cents/kwh) are one of the cheapest in the world at 4 cents for residential and 3 cents for non-residential customers. The cost in lower-middle-income countries is 8 cents for residential and 7 cents for non-residential and in the rate in SSA is 6 and 5 cents, respectively. The most expensive residential prices are in high-income OECD countries with Latin America and Caribbean having the highest nonresidential prices.

\section{Water and sanitation}

Access: Overall access to water is significantly lower than Swaziland's income group as well as all other income groups and regions (Table 2). Only 52\% of the population has access to improved water sources compared to $85 \%$ in lower-middle-income countries and $64 \%$ in SSA. The world average is $80 \%$ with OECD having the highest access to improved water at $99 \%$. Not 
surprisingly, the overall figure hides the deep rural/urban divide. Urban access is at $87 \%$, higher than urban access for SSA and South Asia and not too far from the 94\% access level for lowermiddle-income countries. However rural access to improved water sources is $42 \%$ almost half the level of lower middle-income group and lower than all other groups.

Table 2: Benchmarking Swaziland's Performance in the Water and Sanitation Sectors

\begin{tabular}{|c|c|c|c|c|c|c|c|c|c|c|c|c|c|}
\hline Water & Swaziland & $\begin{array}{c}\text { Main } \\
\text { Benchumark } \\
\text { Lower } \\
\text { Middle } \\
\text { Income } \\
\end{array}$ & SSA & $\begin{array}{l}\text { Middle } \\
\text { East and } \\
\text { Noth } \\
\text { Africa }\end{array}$ & $\begin{array}{l}\text { South } \\
\text { Asia }\end{array}$ & $\begin{array}{c}\text { East } \\
\text { Asia } \\
\text { Pacific }\end{array}$ & $\begin{array}{c}\text { Latin } \\
\text { America } \\
\& \\
\text { Carihbean }\end{array}$ & $\begin{array}{c}\text { Europe \& } \\
\text { Central } \\
\text { Asia }\end{array}$ & $\begin{array}{l}\text { Low } \\
\text { Income }\end{array}$ & $\begin{array}{l}\text { Middle } \\
\text { Income }\end{array}$ & $\begin{array}{l}\text { Upper } \\
\text { Middle } \\
\text { Income }\end{array}$ & $\begin{array}{l}\text { High } \\
\text { Income } \\
\text { OECD }\end{array}$ & World \\
\hline Access to Improved Water Sources (\% of population) & 52 & 85 & 64 & 85 & 72 & 75 & 90 & 87 & 65 & 89 & 93 & 99 & 80 \\
\hline
\end{tabular}

Note: Data used is from the latest observation available between 1997 and 2003.

Source: A "Research" Datahase of Infrastructure Economic Performance, Antonio Estache and Ana Goicoechea, World Bank Infrastructure Network, 0ffice of the Vice President, June 2005.

Access to improved sanitation is slightly better relative to Swaziland's income group with 52\% population having access compared to $72 \%$ for lower-middle-income group and is much better than $37 \%$ for SSA and $48 \%$ for South Asia. Once again the picture is different when it comes to rural/urban comparisons. Rural population with access to improved sanitation is only $44 \%$ compared with $78 \%$ of urban population. 


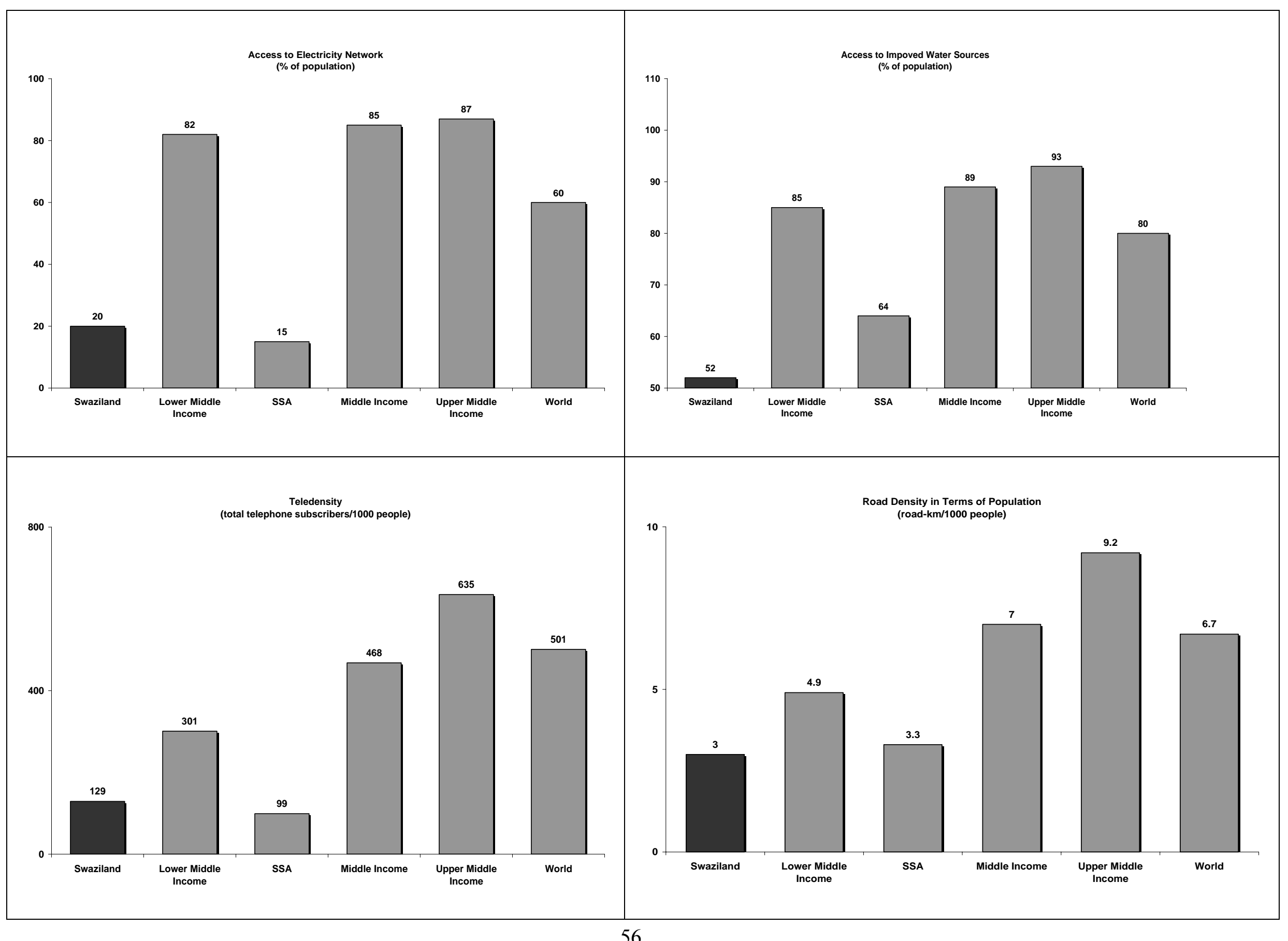




\section{Information and Communications Technology (ICT)}

Access: In terms of mainline teledensity, Swaziland's performance is poor when compared to its comparable income group but better than SSA (Table 3). There are 44 subscribers per 1,000 people, which is just under a third the level for lower-middle-income countries but higher than SSA (31), South Asia (35) and low income (29). Swaziland lags all other regional and income groups. Cellular teledensity is slightly better with Swaziland having half as many subscribers as lower-middle-income group and the gap is narrower with SSA.

Affordability - pricing: A 3-minute local call to the in US cents costs 5 cents in Swaziland, which is half the cost of similar call in SSA and just under 6 cents paid in lower-middle-income countries. Only South Asia is cheaper at 4 cents with high-income OECD countries (15 cents) having the most expensive calls. Cost of a 3-minute international call to the US is one of the cheapest across all regions and income groups with the exception of high-income OECD countries. Cellular call is also amongst the cheapest (only South Asia is lower) at 34 cents per 3 off-peak minutes.

Table 3: Benchmarking Swaziland’s Performance in the ICT Sector

\begin{tabular}{|c|c|c|c|c|c|c|c|c|c|c|c|c|c|}
\hline ICT & Swaziland & $\begin{array}{c}\text { Main } \\
\text { Benchumark } \\
\text { Lower } \\
\text { Middle } \\
\text { Income }\end{array}$ & SSA & $\begin{array}{c}\text { Middle } \\
\text { East and } \\
\text { Noth } \\
\text { Africa }\end{array}$ & $\begin{array}{c}\text { South } \\
\text { Asia }\end{array}$ & $\begin{array}{c}\text { East } \\
\text { Asia } \\
\text { Pacific }\end{array}$ & $\begin{array}{c}\text { Latir } \\
\text { America } \\
\& \\
\text { Cariblear }\end{array}$ & $\begin{array}{c}\text { Europe \& } \\
\text { Central } \\
\text { Asia }\end{array}$ & $\begin{array}{c}\text { Low } \\
\text { Income }\end{array}$ & $\begin{array}{l}\text { Middle } \\
\text { Income }\end{array}$ & $\begin{array}{c}\text { Upper } \\
\text { Middle } \\
\text { Income }\end{array}$ & $\begin{array}{c}\text { High } \\
\text { Income } \\
\text { OECD }\end{array}$ & World \\
\hline Teledensity (total telephone subscribers 1000 people) & 129 & 301 & 99 & 292 & 72 & 172 & 433 & 547 & 64 & 468 & 635 & 1393 & 501 \\
\hline Mainlines Teledensity (mainlines subscribers $/ 1000$ people) & 44 & 126 & 31 & 129 & 35 & 76 & 192 & 224 & 29 & 193 & 261 & 572 & 213 \\
\hline Cellular Teledensity (cellular subscribers/1000 people) & 84 & 179 & 73 & 167 & 37 & 96 & 249 & 325 & 37 & 280 & 381 & 827 & 296 \\
\hline Cost of Local Phone Call(US cents/3 minutes) & 5 & 6 & 10 & 6 & 4 & 5 & 7 & 7 & 8 & 7 & 9 & 15 & 9 \\
\hline Cost of Phone Call to the US (US cents $/ 3$ minutes) & 242 & 314 & 497 & 281 & 336 & 450 & 325 & 326 & 504 & 309 & 305 & 128 & 335 \\
\hline Cost of Cellular Local Call (US cents/3 off-peak minutes) & 34 & 44 & 42 & 52 & 17 & 42 & 57 & 40 & 40 & 49 & 54 & 57 & 49 \\
\hline Phone Faults (reported faults/100 mainlines) & 70 & 33 & 57 & 23 & 97 & 39 & 24 & 34 & 64 & 25 & 18 & 11 & 37 \\
\hline Unmet Demand ( $\%$ of main telephone lines in operation) & 49 & 20 & 50 & 26 & 24 & 13 & 17 & 8 & 47 & 12 & 4 & 0 & 21 \\
\hline
\end{tabular}

Note: Data used is from the latest observation available between 1997 and 2003.

Source: A "Research" Datahase of Lnfrastructure Economic Performance, Antonio Estache and Ana Goicoechea, World Bank Infrastructure Network, 0 ffice of the Vice President, June 2005.

Quality - technical: Swaziland has one of the highest reported faults per 100 telephone mainlines at $70 \%$, compared to $33 \%$ in lower-middle-income countries and 57\% in SSA. Only South Asian region has higher reported faults at $97 \%$. And just under half of all registered applicants for connections are not being satisfied compared to $20 \%$ in lower middle-income countries.

\section{Transport}

Access: Based on two available indicators of access, road density in terms of population (road-kilometers per 1,000 people) is lower than lower-middle-income groups as well as SSA - only South Asia has lower density (Table 4). There are 3 road-km per 1000 people, which is $60 \%$ of lower-middle-income level and one-sixth of density in high-income OECD countries and less than half the world average. Road density in terms of land (road-kilometers per 1,000) lags behind all other regions except SSA and is equal to lowincome group. 
Table 4: Benchmarking Swaziland's Performance in the Transport Sector

\begin{tabular}{|c|c|c|c|c|c|c|c|c|c|c|c|c|c|}
\hline Transport & Swaziland & $\begin{array}{c}\text { Main } \\
\text { Benchumark } \\
\text { Lower } \\
\text { Middle } \\
\text { Income } \\
\end{array}$ & SSA & $\begin{array}{c}\text { Middle } \\
\text { East and } \\
\text { Noth } \\
\text { Africa }\end{array}$ & $\begin{array}{l}\text { South } \\
\text { Asia }\end{array}$ & $\begin{array}{c}\text { East } \\
\text { Asia } \\
\text { Pacific }\end{array}$ & $\begin{array}{c}\text { Latin } \\
\text { America } \\
\& \\
\text { Caribhean }\end{array}$ & $\begin{array}{c}\text { Eurpe \& } \\
\text { Centryl } \\
\text { Asia }\end{array}$ & $\begin{array}{l}\text { Low } \\
\text { Income }\end{array}$ & $\begin{array}{l}\text { Middle } \\
\text { Income }\end{array}$ & $\begin{array}{l}\text { Ipper } \\
\text { Middle } \\
\text { Income }\end{array}$ & $\begin{array}{l}\text { High } \\
\text { Income } \\
\text { OECD }\end{array}$ & World \\
\hline Road Density in Terms of Population (road-knn/1000 people) & 3.0 & 4.9 & 3.3 & 4.8 & 2.4 & 4.2 & 5.7 & 8.6 & 3.0 & 70 & 9.2 & 17.3 & 6.7 \\
\hline Rood Density in Terms of Land ( $(50 d \mathrm{dm} / 1000 \mathrm{sq} \mathrm{km})$ & 181 & 328 & 156 & 609 & 545 & 276 & 713 & 580 & 181 & 702 & 1076 & 1340 & 841 \\
\hline
\end{tabular}

Note: Data used is from the latest observation available between 1997 and 2003.

Source: A "Research" Datahase of Infrastructure Economic Performance, Antonio Estache and Ana Goicoechea, World Bank Infrastructure Network, 0ffice of the Vice President, June 2005.

\section{Large Differences from the Benchmark}

Overall, Swaziland's performance is rather poor in relation to its income group in both access and quality in all four infrastructure sectors (Table 5). Seemingly, performance appears better in low electricity and phone service pricing. This pricing, however, may reflect significant underpricing with associated, poor financial performance of infrastructure companies in Swaziland, with attendant quasi-fiscal losses.

Table 5: Swaziland's Infrastructure Performance: Significant Deviation from Benchmark

\begin{tabular}{|c|c|c|c|c|c|}
\hline & Swaziland & $\begin{array}{l}\text { Benchumark } \\
\text { Lower } \\
\text { Middle } \\
\text { Income } \\
\end{array}$ & SSA & World & $\begin{array}{c}\text { Swaziland's } \\
\text { performance vs. } \\
\text { Benchumark } \\
\end{array}$ \\
\hline \multicolumn{6}{|l|}{ Deviation of $-10 \%$ or more from Benchmark } \\
\hline Energy: Access to Electricity Network (\% of Population) & 20 & 82 & 15 & 60 & Underperform \\
\hline ICT: Teledensity (total telephone subscribers $/ 1000$ people) & 129 & $3 \theta 1$ & 99 & 501 & Underperform \\
\hline ICT: Mainlines Teledensity (mainlines subscribers $/ 1000$ people) & 44 & 126 & 31 & 213 & Underperform \\
\hline ICT: Phone Faults (reported faults $/ 100$ mainlines) & 70 & 33 & 57 & 37 & Underperform \\
\hline Transport: Road Density in Terms of Population (road-km/1000 people) & 3.0 & 4.9 & 3.3 & 6.7 & Underperform \\
\hline Transport: Road Density in Terms of Land (road-km/1000 sq km) & 181 & 328 & 155.7 & 840.6 & Underperform \\
\hline Water: Access to Improved Water Sources (\% of population) & 52 & 85 & 64 & 80 & Underperform \\
\hline Water: Access to Improved Sanitation (\% of population) & 52 & 72 & 37 & 64 & Underperform \\
\hline \multicolumn{6}{|l|}{ Deviation of $+10 \%$ or more from Benchmark } \\
\hline Electricity Average End-User Prices (US cents/kWh) - (Residential/Non-Energy: Residential) & $4 / 3$ & $8 / 7$ & $6 / 5$ & $9 / 6$ & Outperform \\
\hline ICT: Cost of Local Phone Call (US cents/3 minutes) & 5 & 6 & 10 & 9 & Outperform \\
\hline ICT: Cost of Phone Call to the US (US cents/3 minutes) & 242 & 314 & 497 & 335 & Outperform \\
\hline ICT: Cost of Cellular Local Call (US cents 3 off-peak minutes) & 34 & 44 & 42 & 49 & Outperform \\
\hline
\end{tabular}

\section{Conclusion}

Overall, Swaziland's infrastructure performance is rather poor for a country at its income level. The benchmarking suggests major infrastructure deficiencies in all four infrastructure sectors. Basic infrastructure services that perhaps matter most to the poor - water and sanitation - perform particularly poorly. This is also consistent with a recent Public Expenditure Review for Swaziland (World Bank 2006) that documented financial difficulties of several infrastructure companies (e.g., telecom, electricity) and associated problems in service delivery to wide segments of the population. 


\section{REFERENCES}

Aschauer, David.A. (1989). "Is public expenditure productive?" Journal of Monetary Economics, 23:177-200.

Bourguignon, François (2006). "Rethinking Infrastructure for Development," Closing remarks, presented at the World Bank's Annual Bank Conference on Development Economics (ABCDE), Tokyo.

Bogetić, Željko and Johannes W. Fedderke (2006a). "Forecasting Investment Needs in South Africa's Electricity and Telecommunications Sectors," The World Bank Policy Research Paper Series Paper No. 3829 (February).

Bogetić, Željko and Johannes W. Fedderke (2006b). “International Benchmarking of South Africa's Infrastructure Performance," The World Bank Policy Research Paper Series Paper No. 3830 (February); also forthcoming as "South Africa's Infrastructure Performance: An International Benchmarking Analysis," Journal of Development Perspectives (South Africa), Vol.2: 1 (May).

Bogetić, Željko (2006c). “International Benchmarking of Lesotho's Infrastructure Performance,” The World Bank Policy Research Paper Series Paper No. 3825 (January).

Bogetić, Željko and Johannes W. Fedderke (2005). "Infrastructure and Growth in South Africa: Benchmarking, Productivity and Investment Needs," paper presented at the bi-annual conference of the Economic Society of South Africa (ESSA), Durban, September 7-9, 2005.

Calderon and Serven (2004). "The Effect of Infrastructure Development on Growth and Income Distribuution," World Bank Policy Research Paper No. 3400.

Collier, Paul and O’Connell (2004). “Opportunities, Syndromes and Episodes,” mimeo.

De Barros, Gillberto (2005). "Sector note to the Lesotho CAS on telecom and electricity sectors," World Bank, AFTPS.

Easterly, W. and Servén, L. (2002). The Limits of Stabilization: Infrastructure, Public Deficits and Growth in Latin America, Stanford University Press and the World Bank.

Esfahni, H.S., and Ramirez, M.T. (2003). "Institutions, infrastructure and economic growth,” Journal of Development Economics, 70, 443-477.

Estache, Antonio (2006). "Infrastructure: A Survey of Recent and Upcoming Issues," paper presented at the World Bank’s Annual Bank Conference on Development Economics (ABCDE), Tokyo.

Estache, Antonio and Ana Goicoechea (2005). "A 'Research' Database on Infrastructure Economic Performance," Policy Research Paper No. 3643, The World Bank, Infrastructure Network, Office of the Vice President (June), Washington, D.C.

Fedderke, Johannes W. Željko Bogetić (2006). "Infrastructure and Growth in South Africa: Direct and Indirect Impacts of 19 Productivity Measures," paper presented at the international workshop on Infrastructure and Growth: Theory, Evidence and Policy Lessons, Economic Research South Africa, 
University of Cape Town, May 29-31, 2006 (www.econrsa.org; link to “workshops"); also forthcoming as the World Bank Policy Research Series Paper (July 2006).

Fedderke, Johannes, W., Perkins P., and Luiz, J.M. (2005). "Infrastructural Investment in Long-Run Growth: South Africa 1875-2001," World Development, forthcoming.

Kessides, Ioannis, Ž. Bogetić and Luis Maurer (2006). Current and Forthcoming Issues in the South African Electricity Sector, World Bank (March), DEC-AFEG-AFTP4.

Kritzinger van Niekerk, Lolette, Benno Ndulu and Ritva Reinikka (2006). "Infrastructure, Regional Integration and Growth in Sub-Saharan Africa," Africa Region, World Bank (June 13), ppt presentation.

Kuroda, Haruhiko (2006). "Infrastructure and Regional Cooperation," paper presented at the World Bank’s Annual Bank Conference on Development Economics (ABCDE), Tokyo.

Leipziger, Danny (2001). “The Unfinished Agenda: Why is Latin America Lagging Behind?" Finance \& Development, International Monetary Fund, vol. 38, 38-41.

Limao and A. Venables (2001). "Infrastructure, Geographical Disadvantage and Transport Costs and Trade," World Bank Economic Review, Vol. 15, 451-79.

Manuel, Trevor (2005). Budget Speech 2005, Ministry of Finance, Pretoria, South Africa, February 23.

Manuel, Trevor (2006). Budget Speech 2006, Ministry of Finance, Pretoria, South Africa.

Ndulu, Benno (2005). "Infrastructure, Regional Integration and Growth in Sub-Saharan Africa: Dealing with the Disadvantages of Geography and Sovereign Fragmentation," AERC Growth Project.

Perkins, P., J.W. Fedderke, and J. M. Luiz (2005). "An Analysis of Economic Infrastructure Investment in South Africa," South African Journal of Economics, Vol. 73 (2), 211-28.

Reynolds, T, (2005). "Global developments in Telecommunications Pricing," OECD Presentation 14-15 July, Midrand, South Africa.

Truen, S., and Hodge, J. (2005). "Competitive conditions in international bandwidth markets in South Africa: Pricing and regulatory issues in the SAT-3 cable and satellite market," Mimeo: GenesisAnalytics.

World Bank (2006a). Swaziland: Public Expenditure Review: Strengthening Public Expenditure Policy and Management for Service Delivery and Poverty Reduction (March 26), Report No. 3531-SW.

World Bank (2006b). "Private Participation in Infrastructure: A Case for Botswana," (May), Note presented at the World Bank's Tokyo office Roundtable on Infrastructure Development for Small Economies through PPP -- The Case of Botswana.

World Bank (2005a). World Development Report 2005. New York: Oxford University Press.

World Bank (2005b). Lesotho: Country Economic Memorandum-Growth and Employment Options Study (April), Report No. 26130-LSO.

World Bank and BIDPA (2005c). Diversifying Botswana’s Exports: An Overview (July), mimeo.

World Bank (1994). World Development Report 1994: Infrastructure for Development. New York: Oxford University Press. 